\title{
POST-FIRE RESPONSE OF LITTLE CREEK WATERSHED: EVALUATION OF CHANGE IN SEDIMENT PRODUCTION AND SUSPENDED SEDIMENT TRANSPORT
}

\author{
A Thesis \\ presented to \\ the Faculty of California Polytechnic State University, \\ San Luis Obispo \\ In Partial Fulfillment \\ of the Requirements for the Degree \\ Master of Science in Forestry Sciences
}

By

Andrew Wood Loganbill

May 2013 
(C) 2013

Andrew Wood Loganbill

ALL RIGHTS RESERVED 
TITLE:

Post-fire Response of Little Creek Watershed: Evaluation of Change in Sediment Production and Suspended Sediment Transport

AUTHOR:

Andrew Wood Loganbill

DATE SUBMITTED:

May 2013

COMMITTEE CHAIR: $\quad$ Dr. Brian Dietterick, Director, Swanton Pacific Ranch, College of Agriculture, Food and Environmental Sciences, California Polytechnic State University

COMMITTEE MEMBER: Peter Cafferata, Watershed Protection Program Manager, California Department of Forestry and Fire Protection, Sacramento, California

COMMITTEE MEMBER: Dr. Chris Surfleet, College of Agriculture, Food and Environmental Sciences, California Polytechnic State University 


\begin{abstract}
Post-fire Response of Little Creek Watershed: Evaluation of Change in Sediment Production and Suspended Sediment Transport

Andrew Wood Loganbill
\end{abstract}

The Little Creek watershed was assessed to identify changes in event-based suspended sediment export and determine the factors contributing to sediment production the first year following the Lockheed Fire in 2009. The amount and volume of near-stream sediment sources were found to decrease, while an increase in hillslope sediment production was documented. High intensity, short duration rainfall (up to $87 \mathrm{~mm} / \mathrm{hr}$ for 10 minute duration) initiated extensive rilling and minor channel-derived debris torrents originating from the upper south facing slopes. Rainfall simulations, hillslope erosion plots, and soil infiltration tests indicated that fire produced soil water repellency, the lack of ground cover, steep slopes, and high soil burn severity were the most influential factors contributing to hillslope erosion. Contrary to results reported in other western U.S. studies, regression analyses determined that the effect of fire significantly decreased suspended sediment concentrations with higher flows at North Fork and Upper North Fork monitoring stations. The effect of the fire did not produce increases in stormflow volumes and event sediment load, likely due to the fact near-stream sediment contribution was minimal and the majority of hillslope-derived sediment sources were not hydrologically connected. This study provides valuable information for landowners and land managers to understand how a coastal redwood dominated watershed responds to wildfire and prepare post-fire mitigation efforts following future wildfires.

Keywords: wildfire, suspended sediment, hydrologic response, rainfall intensity, hillslope erosion. 


\section{ACKNOWLEDGMENTS}

I would like to give thanks to my committee members, Pete Cafferata for taking time out of his busy schedule to be part of the committee and for his guidance on the project, Chris Surfleet for his insight and review of this document, and Brian Dietterick for giving me the opportunity to study at Cal Poly and Swanton Pacific Ranch, as well as his guidance, and assistance with all aspects of the project.

Enormous thanks are due to all the graduate students Mike Gaedeke, Russ White, Drew Perkins, and Lynette Niebrugge, who contributed to the project throughout the years. Thanks to all the interns and students who helped collect and analyze data, particularly Michael Founds and Nelson Lau with their senior projects contributing to the project. I am greatly appreciative of the statistical assistance from Jack Lewis. Special thanks to the Swanton Pacific Ranch staff for all the support during my time at the ranch. Most of all I would like to thank my family and my wonderful wife who supported me through all the long hours to allow me to reach my goals.

This project was partially funded by McIntire-Stennis, Cal Fire, and California State University Agricultural Research Initiative grant programs. 


\section{TABLE OF CONTENTS}

Page

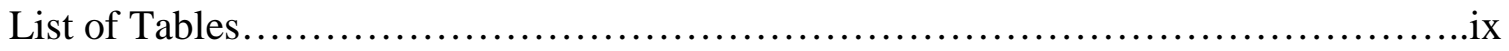

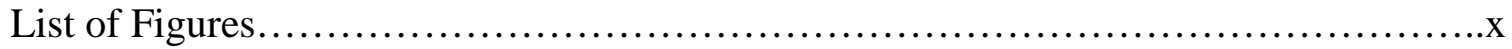

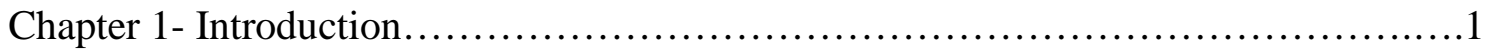

Chapter 2 - Literature Review..................................................4

Chapter 3 - Study Location and Site Description................................11

Management and Project History ....................................... 15

Lockheed Fire....................................................... 18

Chapter 4- Methodology.....................................................22

Stage and Streamflow Data............................................22

Water Quality Data..................................................26

Rainfall Data....................................................29

Near-Stream Sediment Source Survey...................................31

Post-Fire Data Collection...............................................32

Rainfall Simulator..............................................33

Hillslope Erosion Study .......................................36

Soil Infiltration Tests..........................................38

Chapter 5 - Data Analysis and Results.........................................41

Data Analysis..........................................................41 
Suspended Sediment Concentration................................41

North Fork SSC ...........................................44

Upper North Fork SSC......................................45

South Fork SSC..........................................46

Event Sediment Load.................................................47

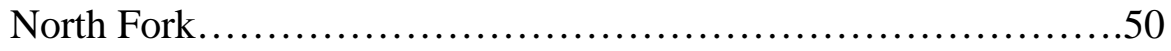

Upper North Fork.........................................51

South Fork..............................................52

Stormflow Volume...................................................53

North Fork.................................................54

Upper North Fork........................................56

South Fork...............................................57

Sediment Source Survey............................................58

Post-Fire Data .......................................................61

Rainfall Simulator.................................................61

Hillslope Erosion Study............................................63

Soil Infiltration Tests.........................................66

Chapter 6 - Discussion...................................................70

First Year Observations of Watershed Response to Post-Fire Storm Events.......70

October 13, 2009 Storm Event......................................71

January 18-21, 2010 Storm Events...............................72

February 6, 2010 Storm Event..................................79

Relationship Between Wildfire and Sediment, Flow, and Precipitation...........80

Suspended Sediment Concentration..................................81

Event Sediment Load..............................................82

Stormflow Volume.............................................83 
Near-stream Sediment Source Survey....................................... 84

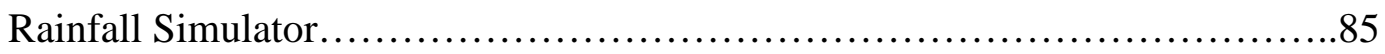

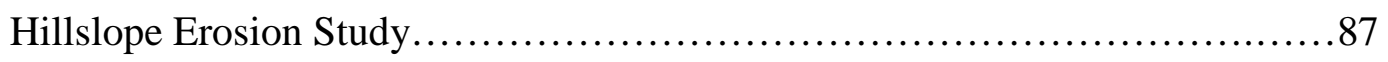

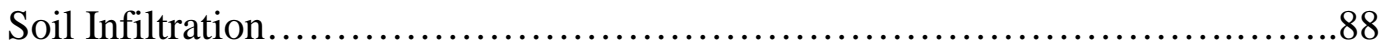

Limitations of Data and Recommendations...................................89

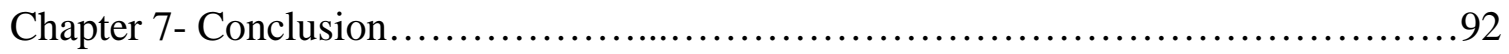

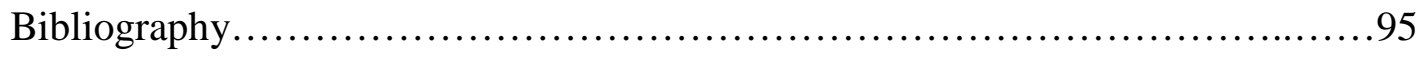

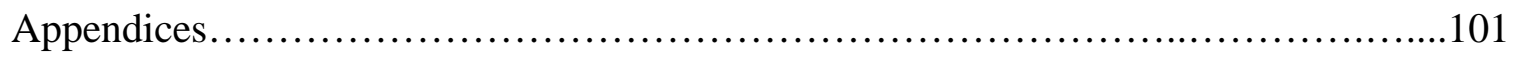

A. Soil Burn Severity Descriptive Classes as Described by Parsons and Robichaud (2003)..................................................102

B. Little Creek Soil Map and Soil Descriptions...............................105

C. Little Creek Monitoring Station Rating Curves...........................106

D. Rainfall Simulator Data/Graphs..........................................109

E. Storm Event Data Summaries...........................................125

F. Hillslope Erosion Plots Data..........................................132 


\section{List of Tables}

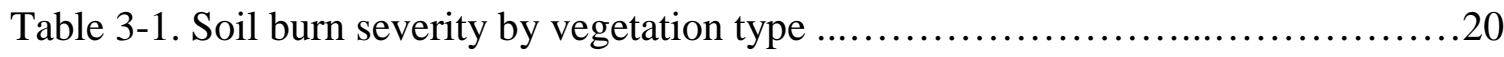

Table 5-1. Regression analysis summary for SSC vs. flow with fire as dummy variable....

Table 5-2. Regression analysis summary sediment load vs. EI30, 28-day precipitation with fire as dummy variable.

Table 5-3. Regression analysis summary for stormflow volume vs. basin precipitation volume 28-day precipitation with fire as dummy variable.

Table 5-4. Summary of near-stream sediment surveys for each year and reach...........59

Table 5-5. Infiltration rate and hydrologic response for rainfall simulator sites..........62

Table 5-6. Annual erosion rates and percent ground cover for Lion’s Flat hillslope erosion study plots......................................................64

Table 5-7. Hillslope erosion plots average erosion rate for slope classes ..............65

Table 6-1. Peakflow and associated maximum SSC for the NF, UNF, and SF monitoring stations during the January 18, 2010 storm event..... 


\section{List of Figures}

Figure 3-1. Location map with Scotts Creek watershed in yellow, Swanton Pacific Ranch boundary in dark red, and Little Creek as shaded area.....................12

Figure 3-2. Geologic map of Little Creek Watershed..............................13

Figure 3-3. Little Creek watershed identifying stream gaging stations and rain gages....17

Figure 3-4. Burn severity map from Lockheed Fire, 2009...........................19

Figure 4-1a. ISCO bubbler flow meter 4230 with rapid transfer device (RTD) connected..............................................................23

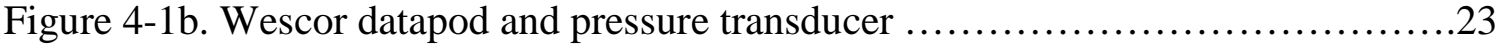

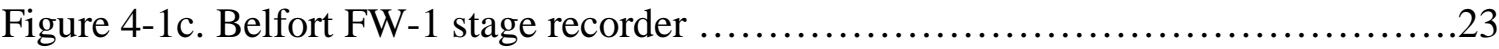

Figure 4-2a. NF rating curve with red points as flow measurements ..................24

Figure 4-2b. SF rating curve with red points as flow measurements...................24

Figure 4-3. UNF rating curve with high flow rating curve in blue, and low flow rating

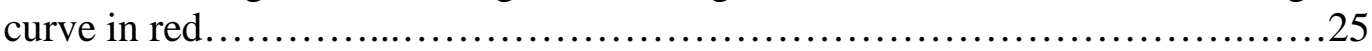

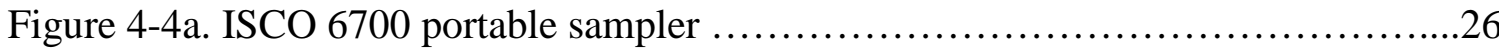

Figure 4-4b. Rated section flume, boom containing sampling tube at the North Fork monitoring station ....................................................26

Figure 4-5. Example of storm event defined by 0.05 slope line intersecting hydrograph prior to turbidity falling below $20 \mathrm{NTU}$ at SF....................28

Figure 4-6. Tipping bucket and manual NWS rain gages at the Ridge line Smith station

Figure 4-7. Cumulative precipitation for LD and UNF rain gages from 2002-2005,

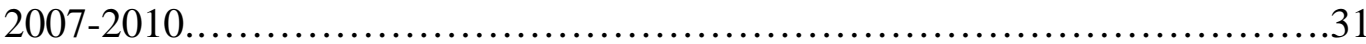

Figure 4-8. Rainfall simulation locations within Scotts Creek Watershed ................34

Figure 4-9. Rainfall simulator in use upslope of the UNF monitoring station ...........36

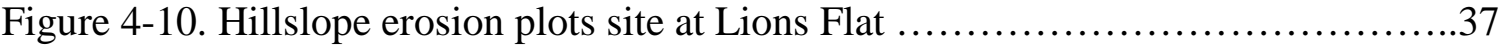

Figure 4-11. Soil Infiltration sites in Little Creek watershed .........................39

Figure 5-1. Fitted versus observed SSC values for South Fork......................47

Figure 5-2. Observed versus fitted values for NF response to model....................51 
Figure 5-3. Scatter plot of observed versus fitted values for UNF response to model with regression lines displaying pre- and post-fire relationships................52

Figure 5-4. Scatter plot of observed versus fitted values for SF response to model with regression lines displaying pre- and post-fire relationships ................53

Figure 5-5. Observed versus fitted values scatterplot of the NF response to model for

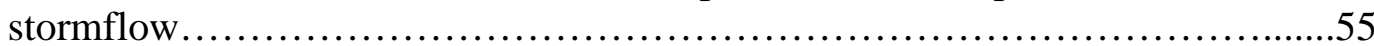

Figure 5-6. Observed versus fitted values scatterplot of the UNF response to model for stormflow........................................................... 57

Figure 5-7. Observed versus fitted values scatterplot of the SF response to model for stormflow... . .58

Figure 5-8. Annual total calculated volume for each near-stream sediment survey.......59

Figure 5-9. Rainfall and runoff plot for rainfall simulation at Upper North Fork site......62

Figure 5-10. Hillslope erosion plot totals for October and January storm events.........65

Figure 5-11. MDI summary for upper and lower slope positions....................67

Figure 5-12. MDI summary for high and moderate soil burn severity.................68

Figure 5-13. MDI summary for North and South facing slope aspect..................69

Figure 6-1. North Fork peakflow plot for entire study period (water years 20032010)..................................................................

Figure 6-2. North Fork SSC versus flow displaying clockwise hysteresis...............74

Figure 6-3. Debris flow deposits on Little Creek Road from R8 tributary ...............76

Figure 6-4. Map of hillslope-derived sediment sources in Little Creek Watershed .....77

Figure 6-5. Rill erosion plot on south-facing slope between NF and UNF monitoring

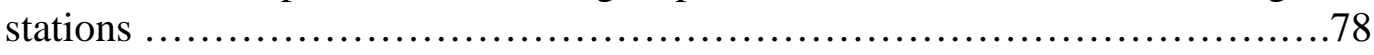

Figure 6-6. Channel scour in swale downslope from extensive rilling caused by a debris flow after the January 18, 2010 storm event .........................79

Figure 6-7. Plot of frequency of feature volumes for each reach and year................84

Figure 6-8. Soil pedestals observed after storm event in Little Creek watershed..........87 


\section{CHAPTER 1}

\section{Introduction}

Wildfire is a natural process that can be both destructive and rejuvenating in a

forested environment. Whether ignited by lightning strike or anthropogenic means, many ecosystems are well adapted to fire. Several plant and tree species rely on fire for regeneration and benefit from the reduction of competing vegetation. The lack of canopy cover and understory vegetation, as well as a change in soil properties following a wildfire can lead to accelerated sediment production (Benavides-Solorio and MacDonald, 2005; Robichaud, 2000). Changes in hydrologic response, including higher baseflows and larger peakflows, are common following a wildfire and can result in flooding (Benda, 2003; Stoof et al., 2012). Fire-induced mobilization of sediment, whether it is slow or rapid and by fluvial and/or gravitational means, can have important implications to land management and adverse short-term effects on water quality and aquatic habitat (Kunze and Stednick, 2006; Campbell and Morris, 1988). While no one can predict wildfire occurrence, it is important to take advantage of the opportunities to research the effects of fire to better understand and mitigate the consequences resulting from sudden changes to ecosystems.

The terms burn severity and burn intensity are often used interchangeably, but these terms are quite different. Parsons (2003) defines soil burn severity as "the firecaused changes to soil hydrologic function, as evidenced by soil characteristics and surface fuel and duff consumption.” Burn intensity is defined by fire behavior and its 
"physical force of the event per area per time period" (Parsons, 2003). In this study burn severity and soil burn severity are used interchangeably and are based on descriptive soil burn severity classes identify by Parsons (2003) in Appendix A.

In managed forests, wildfire is seldom included in management plans. This happened to be the case for California Polytechnic State University's (Cal Poly’s) School Forest, Swanton Pacific Ranch (SPR), located in the coastal mountains near Davenport, California. Cal Poly not only conducts research projects on the property's forested land, but also manages the forested area in accordance with an approved Nonindustrial Timber Management Plan (NTMP). ${ }^{1}$ One major research component is the evaluation of suspended sediment export in the Little Creek watershed before and after a ground-based and cable-yarded timber harvest. A paired and nested watershed study planned on using seven years of pre-harvest data and three years of post-harvest data. The seven years of pre-harvest calibration data were collected by several Cal Poly students and staff and compiled in a thesis by Michael Gaedeke (2006). The post-harvest part of the study was truncated just one year after the timber harvest by the Lockheed Fire in August 2009, which burned approximately $93 \%$ of the Little Creek watershed. Although it was unfortunate that the pre/post timber harvest suspended sediment study abruptly concluded, the wildfire brought an unanticipated opportunity to study the effects of wildfire on coastal redwood-dominated forest.

\footnotetext{
${ }^{1}$ NTMPs are plans approved by the California Department of Forestry and Fire Protection to allow commercial timber harvesting. They must comply with applicable California Forest Practice Rules, and must comply with other state and federal laws and regulations, such as Endangered Species and Clean Water Acts.
} 
While wildfire has been researched in a variety of landscapes internationally, there is little known about the effects of fire on a watershed scale in the coastal mountains dominated by mixed coast redwood/Douglas-fir forest. This study analyzes the watershed response the first year post-fire in the Little Creek watershed. The objectives of this study were:

- Evaluate changes in suspended sediment concentration, event sediment load, and event stormflow occurring the first year post-fire at three stream monitoring stations.

- Assess changes in sediment sources and determine the factors contributing the most influence to sediment production. 


\section{CHAPTER 2}

\section{Literature Review}

Historically fires were ignited naturally by lightning strikes and by anthropogenic means as a way to manage the resources on the land (Stephens and Fry, 2005). In the last century the fire regime has changed dramatically with the implementation of an effective fire suppression program (Greenlee and Langenheim, 1990). The current fire regime and development in rural areas has resulted in increasing amounts of funds to suppress fire and to address adverse effects resulting from fire.

There have been many research efforts to evaluate the significance of wildfire at the watershed scale. While many of these studies were conducted in the western United States, very few studies are located in the coastal redwood forests. The Canoe Fire research project was implemented by Fiori (2005) to understand instream and riparian dynamics in old-growth redwood forest after wildfire. This study focused on aquatic biota, water quality, large woody debris, and channel dynamics. Turbidity and sediment flux were assessed using turbidigraphs comparing Canoe Creek with Bear, Jordan, and Prairie Creeks in Humboldt County, California. The watershed with the least disturbance (Prairie Creek) had the lowest turbidity values; Canoe Creek, the second least disturbed (wildfire impacts), had a wide range of turbidity and suspended sediment concentration (SSC) values; and Bear and Jordan Creeks, the highest disturbed basins (logging impacts), had the highest turbidity values. No significant adverse impacts to salmonid 
habitat resulted from the fire and the highest turbidity and suspended sediment concentration changes were isolated to storm events (Fiori, 2005).

Since wildfire is unpredictable, it is rare to have pre-fire watershed flow and sediment data available for comparison to post-fire data (Moody and Martin, 2001b). Helvey (1980) conducted a study in the Entiat Experimental Forest that was initiated to observe the effects of timber harvest on streamflow parameters. Pre-fire data collection occurred for nine years on three watersheds, Fox, Burns, and McCree Creeks, until wildfires caused by multiple lightning strikes burned a large portion of the forest. Research goals were to determine the effects of fire to streamflow and sediment production for seven years post-fire. The Chelan River was used as a control watershed using data from a USGS gaging station. First-year effects revealed an increase in annual water yield by $50 \%$ compared to predicted values and a dramatic increase in sediment production compared to pre-fire conditions (Helvey 1980). Second-year effects continued to show an increase in flow rates as well as mass soil movement (debris torrents), partially due to rapid snowmelt and intense rainfall. Increased flow rates due to the reduction of transpiration rates and vegetative cover were greater than pre-fire rates for five years following fire and influenced the increase in sediment production (Helvey, 1980).

Changes in streamflow were examined by Campbell and Morris (1988) in the Pack River basin in Idaho following the Sundance Fire that consumed 26\% of the watershed. This study used both single and paired basin methodology with nine years pre-fire data and 15 years of post-fire data. No significant differences were found between mean annual runoff and precipitation for pre-fire and post-fire conditions. The 
paired basin study used data from Boundary Creek and regression analysis was utilized to predict pre- and post-fire streamflow in Pack River. These results documented an increase in post-fire streamflow in March and a decrease in June. It was also found that streamflow peaked earlier post-fire possibly due to decreased canopy cover.

Ryan et al. (2011) quantified changes in sediment loads associated with wildfire in western Wyoming on Little Granite Creek. This study was conducted as a paired watershed study, with a pre- and post-fire component. Pre-fire bedload and suspended sediment data were collected from the years 1982-1997. The wildfire occurred in 2000 and post-fire data was collected for a three-year duration in order to evaluate sediment dynamics from snowmelt runoff and precipitation events, quantify differences in suspended sediment for burned and unburned watersheds, and to compare pre- and postfire sediment yields. The first three years post-fire had low snowpacks and few summer rainfall events. Only one event produced a significant increase in stream discharge that exceeded pre-fire levels. The most pronounced spikes in SSC were observed the first year post-fire during rainstorms. SSC was nine times greater than pre-fire levels during peakflows and several orders in magnitude greater during summer flows. SSC spikes declined over the next two years of the study due to many factors, including an increase in vegetation and a decrease in available sediment. First year sediment yields were five times greater than predicted for the pre-fire period (Ryan et al., 2011).

Kunze and Stednick (2006) studied streamflow and suspended sediment yield following the Bobcat Fire in the Colorado Front Range. Precipitation, streamflow, and suspended sediment were measured at two watersheds that were burned in the Bobcat Fire in 2000. Linear regression was used to assess the relation between rainfall intensity 
and dependent variables of peakflow, storm runoff, and suspended sediment yields in each watershed. Thirty-minute rainfall intensity was highly correlated to peak discharge, storm runoff, and sediment yield in both watersheds. Data suggests that soil sealing and loss of ground cover were responsible for high peakflows the first two years after the fire. The majority of the sediment yield in 2001 was generated from one or two intense storms with recurrence intervals of less than or equal to two years.

Sediment and ash delivery after the Cerro Grande Fire in 2000 was analyzed in a small reservoir in New Mexico. The sedimentation record in the Los Alamos Reservoir was studied for five years post fire and determined that $90 \%$ of ash was delivered in the first year. Fine sediment also decreased after the first year, although sediment loads were well above pre-fire average after 5 years post-fire. Sedimentation rates increased by approximately 140 times the annual pre-fire rate the first year after the fire. Sediment transport rates declined rapidly after the first year post-fire despite the occurrence of higher intensity storm events (Reneau et al., 2007).

In southeastern Australia, Smith et al. (2011) studied changes in sediment sources and erosion processes following wildfire in two forested watersheds. The watersheds, located in the East Keiwa River Valley, were previously studied to understand the effects of logging on water quality and sediment yield. Fallout radionuclides were used to trace sediment sources for 3.5 years post-fire. Surface material accounted for the majority of post-fire sediment exports and there was a sharp decline of surface material contribution after the first year post-fire. Increase in groundcover and breakdown of water repellent soil layers explained the decline in hillslope surface sediment export. Two rainfall events with high rainfall intensity accounted for $79 \%$ of total suspended sediment load. 
Rainfall intensity often has direct correlation to changes in flow parameters and sediment production following wildfire. Spigel and Robichaud (2007) used silt fences to measure erosion rates the first year post-fire on steep slopes with high burn severity in the Bitterroot National Forest, located in Montana. Rainfall data was recorded and sediment was collected and analyzed after each storm event. Short duration, high intensity rainfall events were found to produce the highest erosion rates, while short duration, low intensity rainfall events produced minimal erosion.

Sediment production is often elevated following a wildfire due to many factors. Benavides-Solorio and MacDonald (2005) found that fire severity, percent bare soil, rainfall erosivity, soil water repellency and soil texture explained $77 \%$ of the variability in sediment production rates when studying three wildfires and three prescribed fires in the Colorado Front Range. The appropriate combination of factors (available sediment, steep slopes, bare soils, hydrophobic soils, and high volume and intensity rainfall), creates the potential for debris flows or torrents following fire (Spittler, 1995). Several debris torrents were observed following wildfire in the Entiat Experimental Forest due to rapid snowmelt and high rainfall intensity (Helvey, 1980). Sediment response following the Painted Cave Fire in Santa Barbara did not result in debris flows, but did result in a high rate of sediment flushing from the hillslopes in the first three years following the fire (Keller et al., 1997).

Several factors affect post-fire soil erodibility. Soil sealing commonly results from high soil burn severity and can influence overland flow and enhance hillslopederived erosional processes (Doerr et al., 2010; Ice et al., 2004; Huffman et al., 2001; Spittler, 1995). Water repellency is also commonly increased following wildfire 
(DeBano, 2000). For example, water drop penetration time (WDPT) tests were conducted on soils at multiple depths in the Colorado Front Range and soils often displayed strong hydrophobicity up to depths of $6 \mathrm{~cm}$ in moderate and high severity burn sites. It was also observed that hydrophobicity increased with increasing percent sand in soils (Huffman et al., 2001). Soil water repellency was tested using the WDPT method pre- and post-fire in a steep chaparral watershed (Hubbert et al., 2008). Thirty-eight percent of pre-fire sites displayed moderate to high repellency and increased to 66 percent of sites displaying moderate to high repellency shortly after the fire. Soil water repellency was reduced to pre-fire levels 76 days after the fire (Hubbert et al., 2008). Soil water repellency often has spatial variability and is influenced by macropores produced by insects and burrowing animals. Ground cover plays a large role in water repellency and can be more important in controlling post-fire erosion than soil water repellency (Doerr et al., 2010).

Larsen et al. (2009) conducted a study using rainfall simulations as a method to compare runoff, erosion, and surface sealing from soils with varying ground and ash cover. The results indicated that soil surface cover was more influential to sediment production than soil water repellency. This study also found that ash cover temporarily prevented soil sealing and reduced runoff and sediment yields. Rainfall simulations by Benavides-Solorio (2003) found that high burn fire severity plots yielded 16-33 times more sediment than low severity and unburned plots.

A variety of methods using numerous parameters are available to study watershed response to wildfire. Increase in sediment production associated with fire-induced water repellent soils, reduction of ground cover, and high intensity rainfall events have been 
commonly documented. Increases in peakflows are commonly measured, especially after the first year post-fire. There is a lack of research, however, documenting how wildfire affects sediment production and streamflow in the Coastal Mountains in a coast redwooddominated forest. 


\section{CHAPTER 3}

\section{Study Location and Site Description}

This study took place in the Little Creek watershed, 769 ha subwatershed to the 6734 ha Scotts Creek watershed located in the Santa Cruz Mountains along the Central Coast of California. The Scotts Creek watershed is located approximately $19 \mathrm{~km}$ north of Santa Cruz (Figure 3-1) and drains to the Pacific Ocean about two km north of the town of Davenport. The lower half of the 501 ha Little Creek watershed is owned by the California Polytechnic State University Corporation for the operation of an educational and research facility known as Swanton Pacific Ranch. ${ }^{2}$ The majority of the 268 ha upper watershed, formerly owned by the Cemex Corporation was recently acquired by a group of five local and Bay area conservation groups as part of the Living Landscape Initiative. One other smaller parcel is privately held.

\footnotetext{
${ }^{2}$ Al Smith generously donated the 1,327 ha Swanton Pacific Ranch to Cal Poly in 1993 as a working ranch (agriculture, livestock, and forestry) and a "natural classroom” for educational opportunities.
} 


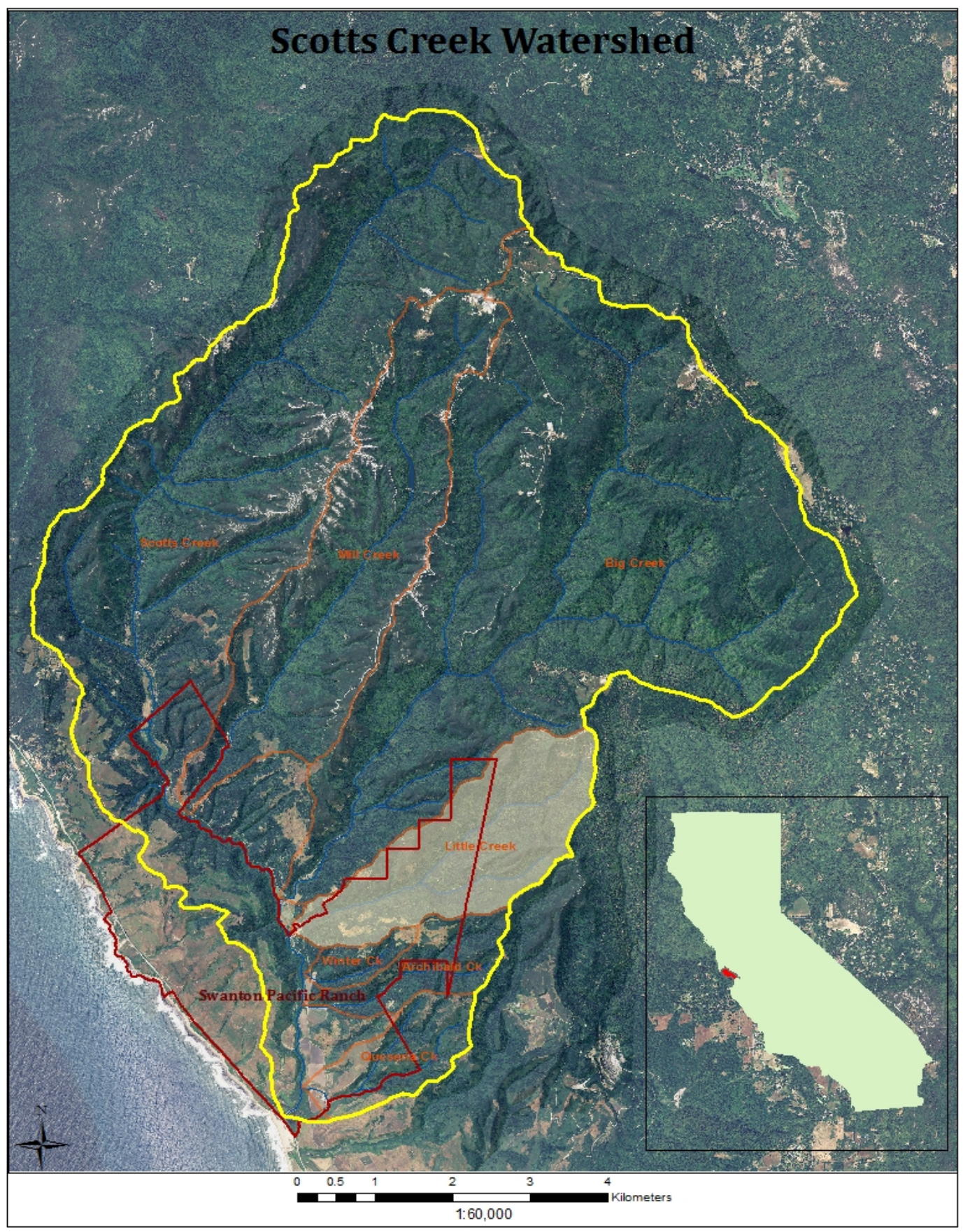

Figure 3-1. Location map with Scotts Creek watershed in yellow, Swanton Pacific Ranch boundary in dark red, and Little Creek as shaded area. 
The Santa Cruz Mountains experience rapid geologic uplift due to a slight bend in the San Andreas Fault that causes the Pacific plate to drive the land upward (Scotts Creek Watershed Assessment, 2005). This geologic uplift accompanied by wet winters creates a steep and rugged terrain. The geology of Little Creek watershed is situated on a tilted block (southwestern direction) composed of Santa Cruz mudstone (upper Miocene) overlying a thin layer of Santa Margarita sandstone (upper Miocene) and quartz diorite (Cretaceous), with some outcrops of schist underlying the block (Brabb, 1997). Santa Cruz mudstone is found in the lower portion of the Little Creek watershed up to the confluence of the North and South Forks. Quartz diorite and outcrops of schist are found along the channel above the confluence and slowly expands to the upper slopes upstream through to the headwaters of the watershed (Figure 3-2).

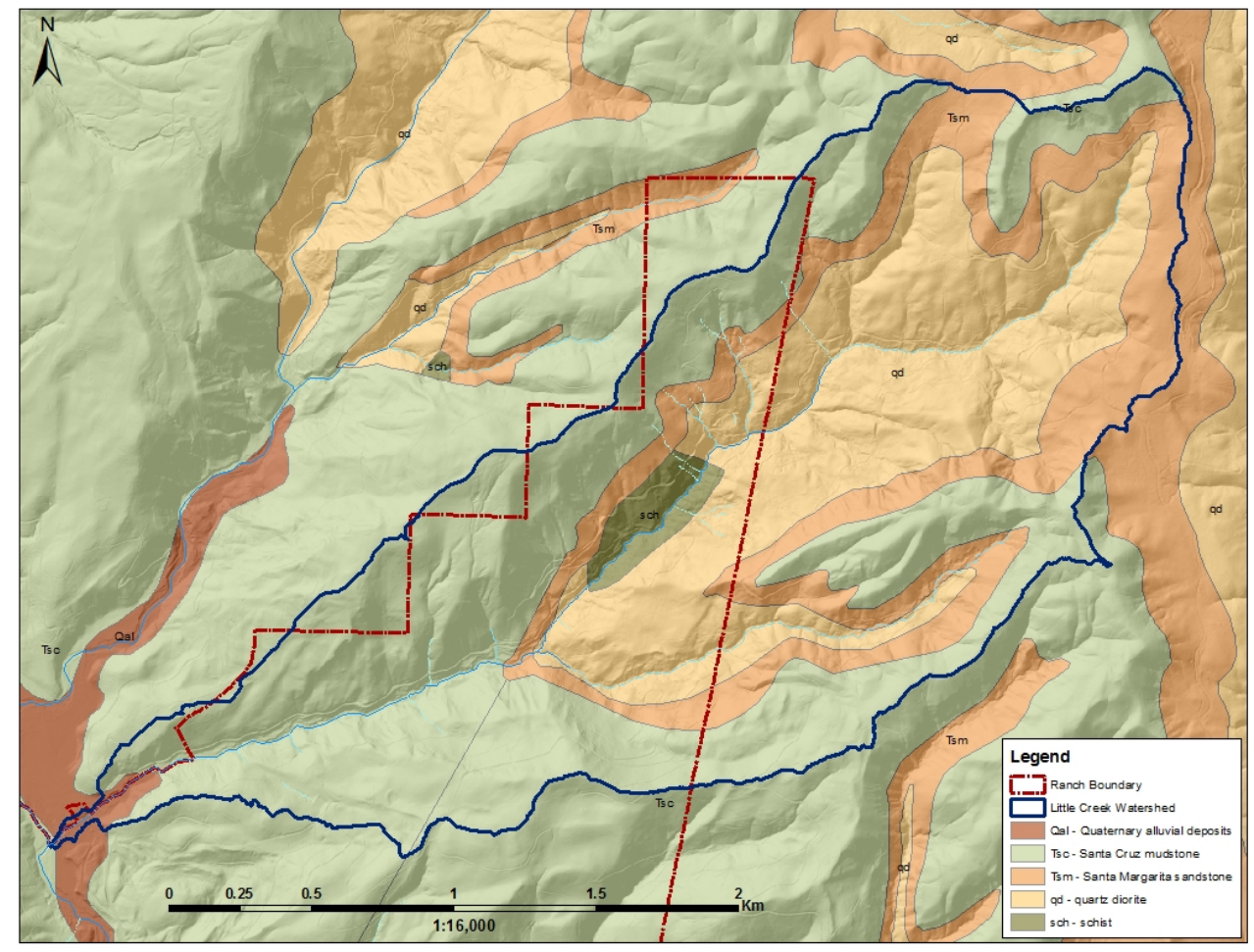

Figure 3-2. Geologic map of Little Creek Watershed. 
The Santa Cruz Mountains experience a Mediterranean climate with mild temperatures. The majority of precipitation occurs in the winter months, with an average of 100-130 cm annually in the upper Little Creek watershed due to orographic lift; the lower elevations average $75 \mathrm{~cm}$. Summer months are dry, although fog commonly keeps the forested portions of the watershed moist from fog drip. Many areas of Little Creek have inner gorge characteristics. The average basin slope is 45 percent and elevation ranges from $12 \mathrm{~m}$ to $488 \mathrm{~m}$ (White, 2010). The watershed is composed of Class I, II, and III watercourses, as defined by the California Forest Practice Rules (2013). Rock migration barriers for coho salmon and steelhead trout located a short distance past the confluence of the North Fork and South Fork delineate the change for a Class I to Class II watercourse. Little Creek contains first- and second-order channels with stream gradient greater than $2 \%$. The channel type and bed type vary throughout the watershed. Channel type, according to Montgomery and Buffington (1997), varies from plane-bed, step-pool, cascade, and bedrock, while bed type varies from gravel, cobble, boulder, and rock (Perkins, 2012).

The Ben Lomond Catelli-Sur complex is the predominate soil type, composing approximately one-third of the Little Creek watershed. This soil type is a sandy loam located along the riparian corridor and on the lower slopes of the watershed. The Maymen/Rock outcrop complex is the common soil type on the ridges and Santa Lucia shaly clay loam is common on the south facing upper slopes. Other soil types present in the watershed are Lompico/Felton complex, Tierra/Watsonville complex, and Bonnydoon loam (NRCS Soil Web Survey, 2012). A soil map is located in Appendix B. 
Second-growth coast redwood (Sequoia semprevirons) and Douglas-fir (Pseudotsuga menziesii) are the dominant conifer species present in the Little Creek watershed. A substantial tanoak (Lithocarpus densiflora) component is present on the north facing slopes and mid to lower slopes of Little Creek watershed. South facing and upper slopes progress from Douglas-fir and tanoak to chaparral, with the ridges are covered with knobcone pine (Pinus attenuate). Red alder (Alnus rubra), California bay laurel (Umbellularia californica), bigleaf maple (Acer macrophyllum), and redwood are the dominant riparian overstory species. The understory vegetation consists of a variety of ferns, shrubs, legume, and grass species. Manzanita (Arctostaphylos), chamise (Adenostoma fasciculatum), and coyote bush (Baccharis pilularis) are the dominant shrub species which are particularly found on the upper south facing slopes of the watershed.

\section{Management and Project History}

The Little Creek watershed has been managed for timber production since 1906. Large areas in the Santa Cruz Mountains were clearcut mainly to supply San Francisco with timber to rebuild after the 1906 earthquake. The timber was hauled to mills by railroad and it is still common to find old railroad artifacts in Little Creek. Following the initial timber harvest, the watershed became an even-aged stand of second growth redwood and Douglas-fir. A second timber harvest occurred in the 1950's in various areas of the watershed, with only premium timber selected. When Cal Poly started to become associated with Swanton Pacific Ranch in the late 1980's, a new forest management regime began to focus on producing an uneven-aged forest with sustainable 
yields (SPR Management Plan, 2004). First entry under this new regime occurred in 1990, selectively harvesting a small unit in the North Fork, and was followed by harvests in various units in 1993-95, 2008, 2010, and 2011.

The Little Creek Study was designed to evaluate event-based suspended sediment transport before and after a timber harvest using a paired and nested watershed study design. The study was expected to provide scientific documentation regarding the effectiveness of best management practices as defined in the California Forest Practice Rules. In order to collect the necessary data for this project, three rated section flumes at Main Stem (MS), North Fork (NF), and South Fork (SF) were constructed in 1997 (Figure 3-3). The 1997-98 storm season was a record year in the area and high flows damaged the newly-constructed flumes. By 2000 the flumes were repaired, and the 2000-01 winter was the first year of data collection (water year 2001). In 2001 a rated natural channel stream gaging station was constructed in the Upper North Fork (UNF) near the Swanton Pacific Ranch property line (Figure 3-3). Five additional flumes were constructed in 2007 in two tributaries of the North Fork, with the objective of understanding suspended sediment export and flow characteristics in non-fish bearing Class II and III watercourses. Of the four main gaging stations and five tributary stations, only North Fork (NF), South Fork (SF), and Upper North Fork (UNF) data were used in this study. The South Fork served as the control for the paired component of study, while the Upper North Fork was the control in the nested component. 


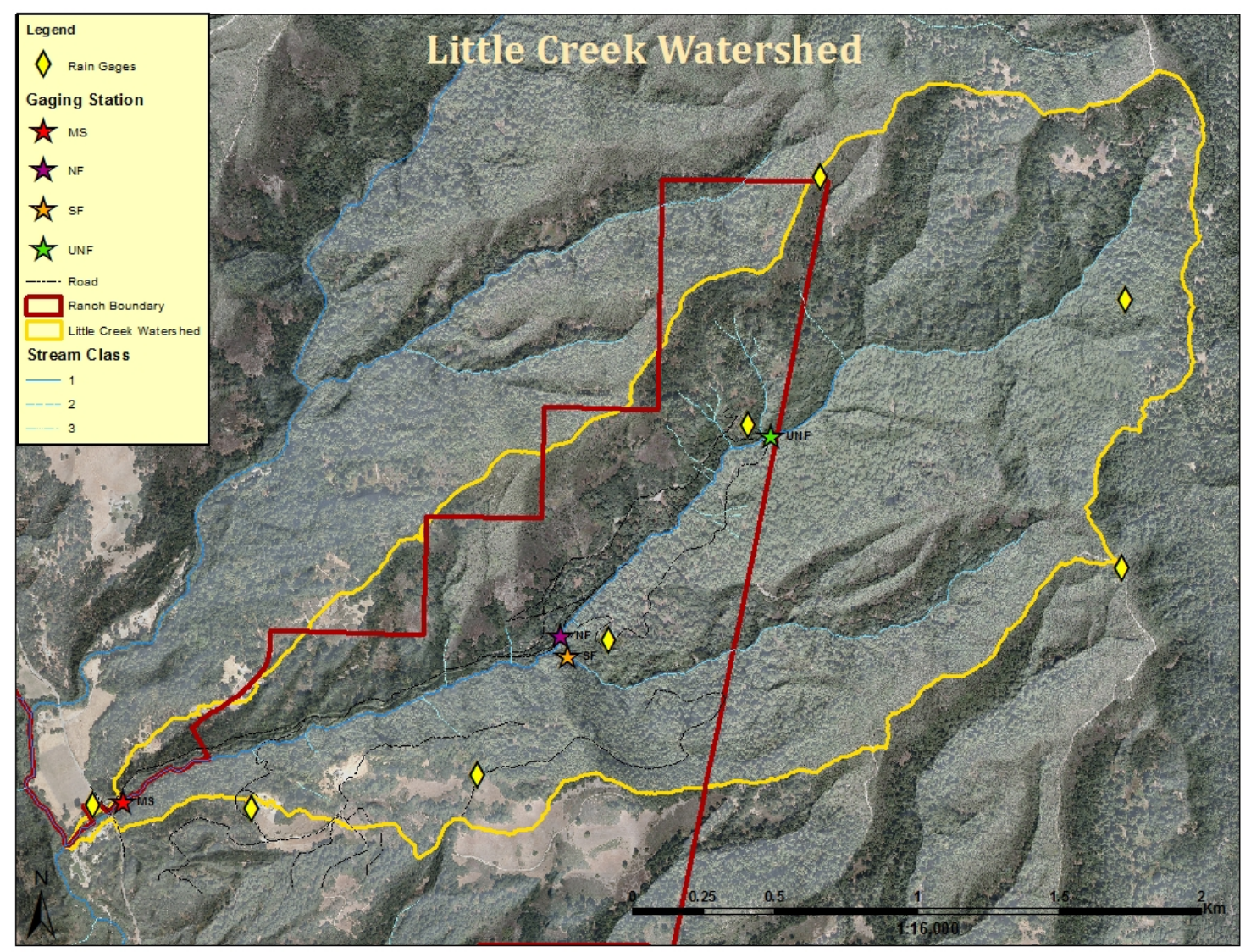

Figure 3-3. Little Creek watershed identifying stream gaging stations and rain gages.

Seven years of pre-treatment data were collected from 2001 to 2008 in order to calibrate the watershed. Gaedeke (2006) stated that from calibration component results, “changes in storm event suspended sediment loads approximately 30\% above background levels may be detected for the nested watershed design, while changes of approximately 90\% may be needed to detect change in the paired watershed design.”

In the summer of 2008 the North Fork Unit, as delineated in the Swanton Pacific Ranch NTMP, was selectively harvested using both ground and skyline cable yarding methods. The post-treatment analysis began upon completion of the timber harvest and was designed to evaluate three years of water quality data. The 2008-09 storm season following the timber harvest was one of the driest years of the study, with only three 
defined storm events and below average rainfall. In August 2009 the Lockheed Fire occurred, burning both the control and treatment watersheds and terminating the initial project design, with only one below average year of post-treatment data.

\section{Lockheed Fire}

On August 12, 2009 the Lockheed Fire incident began, ultimately burning 3,164 ha almost completely within the Scotts Creek watershed (Figure 3-4). Almost the entire Little Creek was affected by the fire in varying intensities resulting in approximately 93\% consumption of the watershed. The fire destroyed one tributary flume, damaged two additional tributary flumes, damaged the NF and SF flumes, destroyed three automated samplers, and destroyed two rain gages. Burn severity varied throughout the watershed and was estimated at $6 \%$ low, $43 \%$ moderate, $37 \%$ high, $14 \%$ very high severity (Lockheed Fire Post Fire Risk Assessment, 2009). Burn severity was highest on ridges in chaparral and knobcone pine vegetation types and generally moderate to low in redwood forest and grassland areas. Some areas in the coast redwood/Douglas-fir forest type experienced high burn severity with full canopy consumption. Soil burn severity by vegetation type is displayed in Table 3-1. Burn severity maps were created using Burned Area Reflectance Classification (BARC) (Hudak et al. 2004), which uses soil burn severity indicators defined by Parsons (2003). 


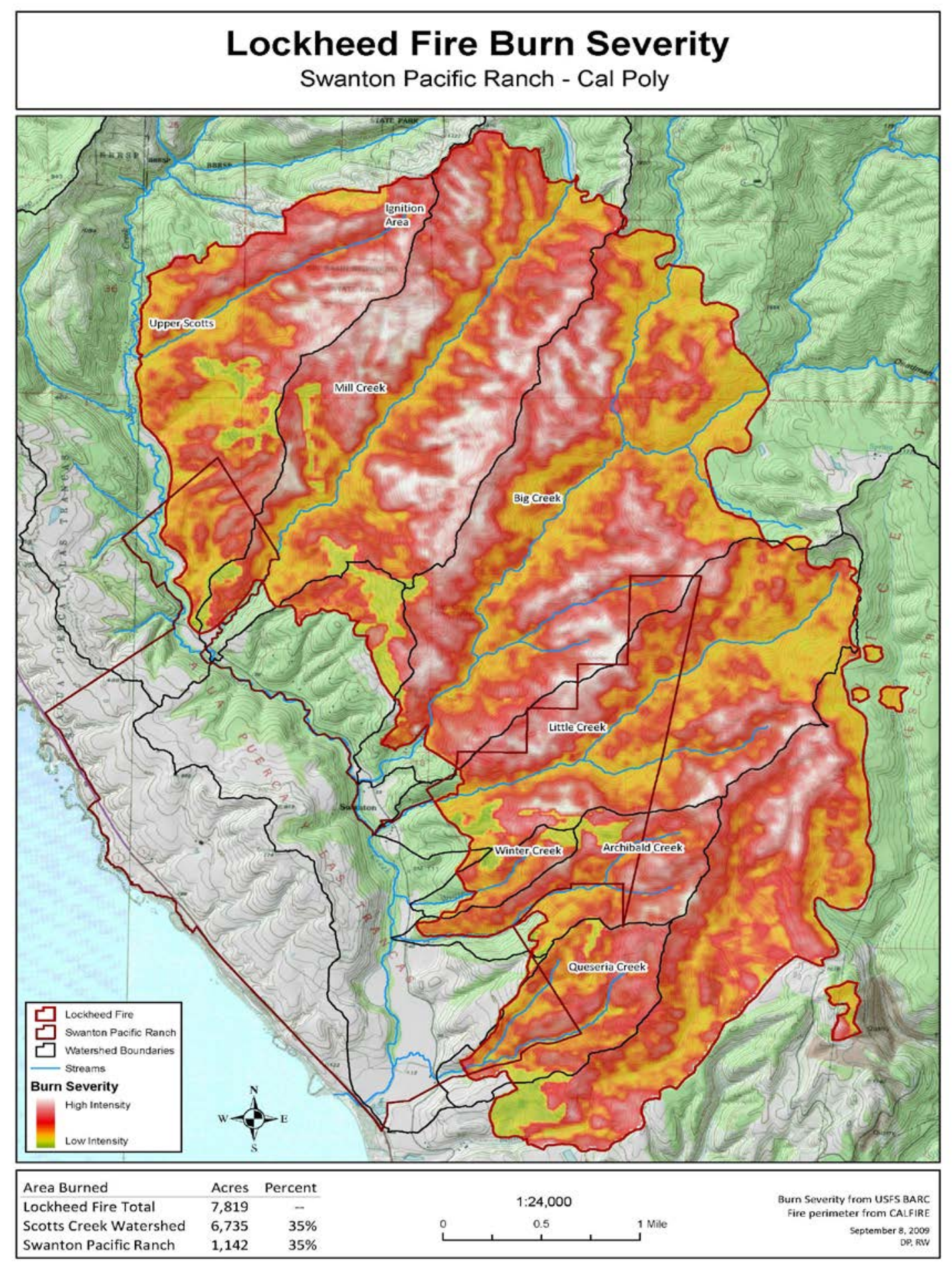

Figure 3-4. Burn severity map from Lockheed Fire, 2009. 
Table 3-1. Soil burn severity by vegetation type (Lockheed Fire Post fire Risk Assessment, 2009)

\begin{tabular}{|l|l|l|l|l|l|}
\hline Vegetation Type & $\begin{array}{l}\text { Area } \\
\text { Burned } \\
\text { (ha) }\end{array}$ & $\begin{array}{l}\text { Very High } \\
\text { Severity } \\
\text { (ha) }\end{array}$ & $\begin{array}{l}\text { High } \\
\text { Severity } \\
\text { (ha) }\end{array}$ & $\begin{array}{l}\text { Moderate } \\
\text { Severity } \\
\text { (ha) }\end{array}$ & $\begin{array}{l}\text { Low } \\
\text { Severity } \\
\text { (ha) }\end{array}$ \\
\hline Redwood Forest & 979 & 17.4 & 240 & 667 & 55.6 \\
\hline Mixed Conifer Forest & 790 & 37.6 & 283 & 448 & 21.0 \\
\hline Chaparral & 981 & 372 & 489 & 112 & 8.9 \\
\hline Coastal Scrub & 217 & 6.9 & 124 & 78.9 & 6.9 \\
\hline Grassland & 138 & 0 & 21.9 & 8.9 & 108 \\
\hline Agriculture & 17.0 & 0 & 4.0 & 11.3 & 0.8 \\
\hline Monterey Pine & 15.0 & 0 & 6.9 & 7.3 & 0.8 \\
\hline Quarry/Town & 1.6 & 0 & 0 & 0.4 & 1.2 \\
\hline Oak Woodland & 6.1 & 0 & 1.2 & 4.9 & 0 \\
\hline
\end{tabular}

Historically coast redwoods in the Santa Cruz Mountains were frequently burned by the Ohlone (Costanoan) tribe for means of increasing food production. The mean fire return interval associated with the Ohlone tribe was estimated at12 years (Stephens and Fry, 2005). Prior to the Native American inhabitance, the fire regime was thought to be ignited by lightning and had a longer fire return interval. Fire regime was slightly changed when the Spanish began to inhabit the area, although frequent fires still occurred. As the population started to grow and modernization began, fire suppression lengthened the fire return interval to 130 years (Greenlee and Langenhiem, 1990). The Scotts Creek watershed experienced the Pine Mountain Fire in 1948 which was nearly twice the size of the Lockheed Fire, yet it did not reach as far west and south. The Pine 
Mountain Fire burned much of the same area as the Lockheed Fire, although the Lockheed fire extended further into the lower reaches of the watershed.

Salvage logging was performed in the spring of 2010 by helicopter logging, but logging operations were not a factor in this study. The upper watershed, then owned by the CEMEX Corporation, was logged by helicopter, cable-yarding, and ground-based logging methods in the summer of 2010. This harvest did not have an influence to this study, but there is potential influence for future studies in the Little Creek watershed. 


\section{CHAPTER 4}

\section{Methodology}

\section{$\underline{\text { Stage and Streamflow Data }}$}

Each monitoring station used multiple instruments to record stage (Figure 4-1). The primary and most reliable stage recording device used in this study was the Isco ${ }^{\circledR}$ 4230 Bubbler Flow Meter. The bubbler flow meter records stream stage at 15 minute intervals by measuring the amount of pressure used to force an air bubble through a submerged bubble line. Stilling wells were used to reduce turbulence resulting from open channel measurements and therefore improve data accuracy. Secondary stage recording equipment included a Wescor ${ }^{\circledR}$ water level sensor (pressure transducer), Belfort ${ }^{\circledR}$ FW-1 stage recorder, ${ }^{3}$ and Telog ${ }^{\circledR}$ data recorder with a Druck ${ }^{\circledR}$ pressure transducer. These secondary stage recording devices were used to clarify data discrepancies or to replace periods of missing data resulting from equipment failures or power outages. Additionally, staff plates were located at each monitoring station and stage was manually recorded.

\footnotetext{
${ }^{3}$ Stage recorders create a hydrograph over time using a float and pulley system and a manual winding clock.
} 

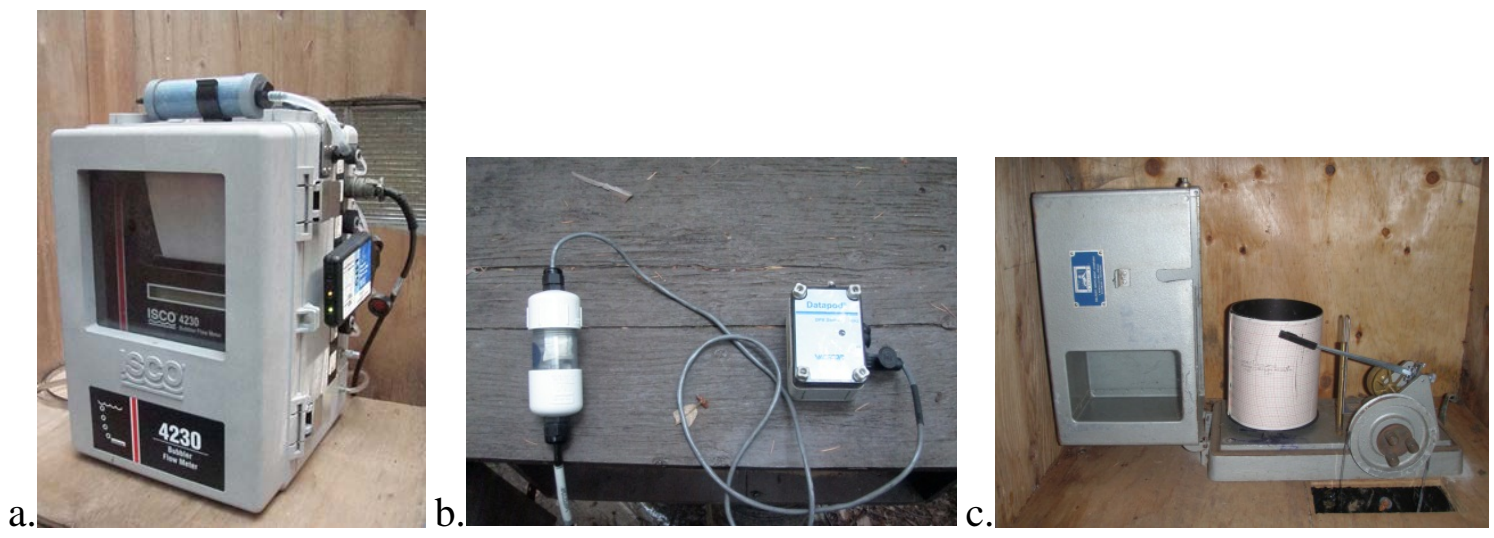

Figure 4-1. a) ISCO bubbler flow meter 4230 with rapid transfer device (RTD) connected; b) Wescor datapod and pressure transducer; and c) Belfort FW-1 stage recorder.

Independent streamflow measurements were taken at different stage heights at each station to create a rating curve. A rating curve allows stage data to be converted into flow using a quadratic equation derived from regression analysis of manual flow measurements at different stage heights (Figure 4-2). The protocol for streamflow measurements followed procedures stated by the USGS in “Discharge Measurements at Gaging Stations” (Turnipseed and Sauer, 2010) using an electromagnetic current meter from Marsh-McBirney, Inc. Manual flow measurements were taken periodically throughout the project to fill in gaps and improve the rating curves, as well as to check accuracy of previous data to ensure that the channel or flume has not changed from storm events. 
a)

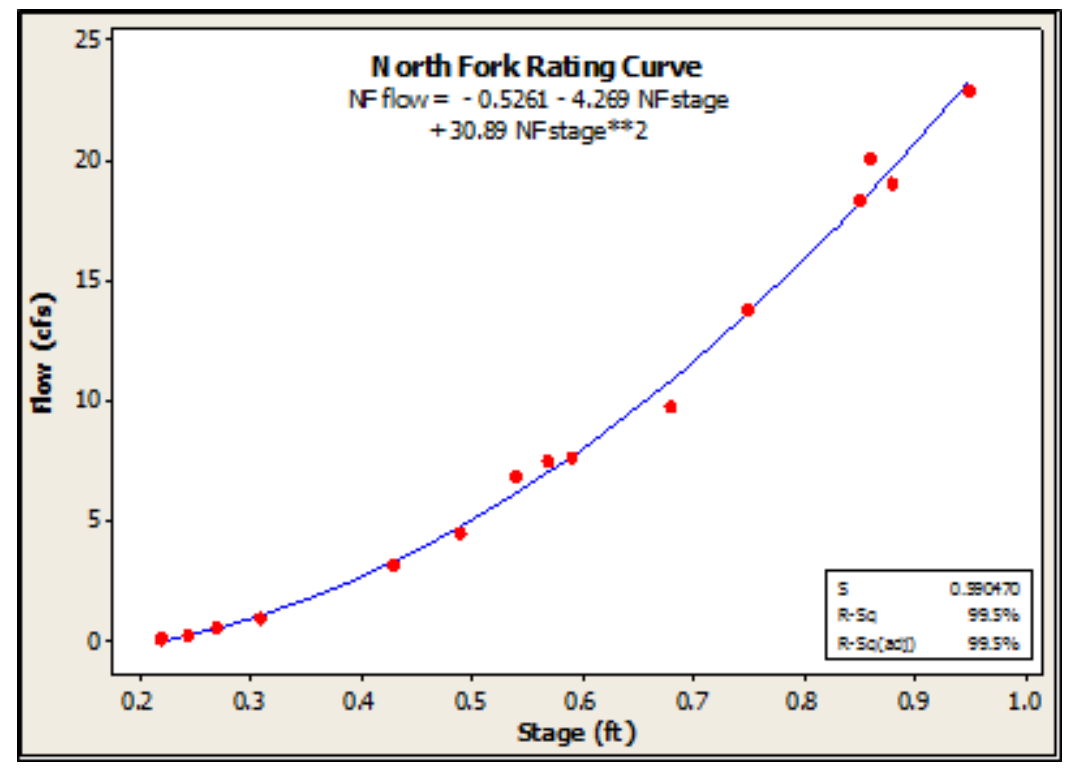

b)

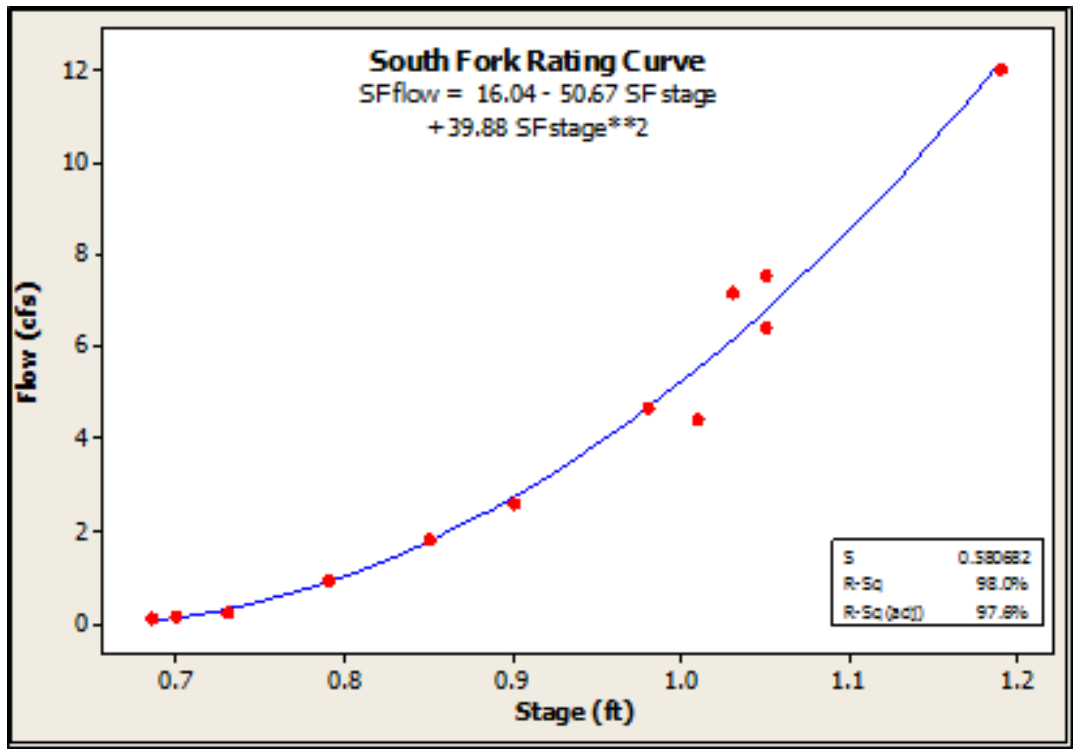

Figure 4-2 a) NF rating curve with red points as flow measurements. b) SF rating curve with red points as flow measurements. The blue line is the fitted regression line.

The UNF monitoring station had some discrepancies with rating curve data through the years due to the fact that it is a natural channel monitoring station and is susceptible to channel changes. The stilling well at UNF was located in a deep pool 
where the tail of the pool was controlled by granite boulders. Observations during the last two years (2008-2010) have shown that the dynamic nature of stream results in changes in the height of the tail of the pool due to aggradation, degradation, and small debris jams. It was believed that through maintenance of clearing debris from the pool, the stage was stable enough to create a rating curve, but the quality of data was questionable due to fluctuations in pool height. To improve rating curve accuracy at UNF, eight flow measurements were taken during the 2009-10 winter. Older streamflow measurements that did not fit well were omitted and a new rating curve was created with two parts: high flow rating curve (stage $>0.43 \mathrm{~m}(1.40 \mathrm{ft})$ ) and a low flow rating curve (stage $<0.45 \mathrm{~m}(1.49 \mathrm{ft})$ ). This duel rating curve approach was used for the last three years while the previous rating curve was used for other years (Figure 4-3). The previous UNF rating curve was created by Gaedeke (2006) using a linear interpolation for stage less than $0.30 \mathrm{~m}$ ( 0.99 feet) and a quadratic equation for stage greater than $0.30 \mathrm{~m}(0.99$ feet). See Appendix C for rating curve equations, graphs, and data.

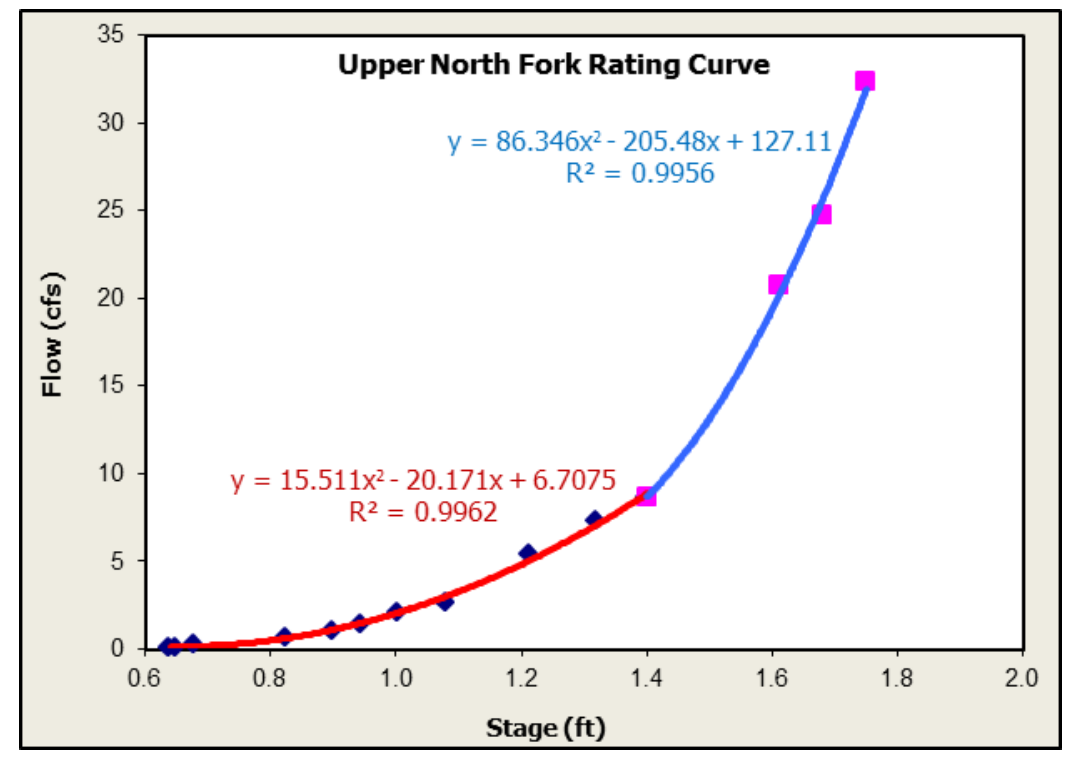

Figure 4-3. UNF rating curve with high flow rating curve in blue, and low flow rating curve in red. 


\section{Water Quality Data}

Event-based water quality sampling requires researchers to be extremely attentive to weather patterns. When storm events occurred water samples were collected hourly at each station for the duration of the storm event until turbidity levels drop below 20

NTUs. Water samples were collected automatically with an Isco ${ }^{\circledR} 6700$ or 6712 automated water sampler (Figure 4-4a). The samplers were programmed to pump 350mL samples hourly and were set to operate continuously through each storm event. Samples were pumped through 3/8 inch PVC tubing situated on a swinging metal boom suspended in the active stream channel such that the intake was maintained in the upper half of the water column to prevent pumping of bedload (Figure 4-4b). Samplers contain 24 oneliter bottles which were replaced every 24 hour time period. Field crews visited stations frequently during storm events to address issues that can possibly hamper sampling process such as switch bottles sets, replace batteries, adjust intake relative to flow, remove debris that may be clogging pump intake or stilling well intake.
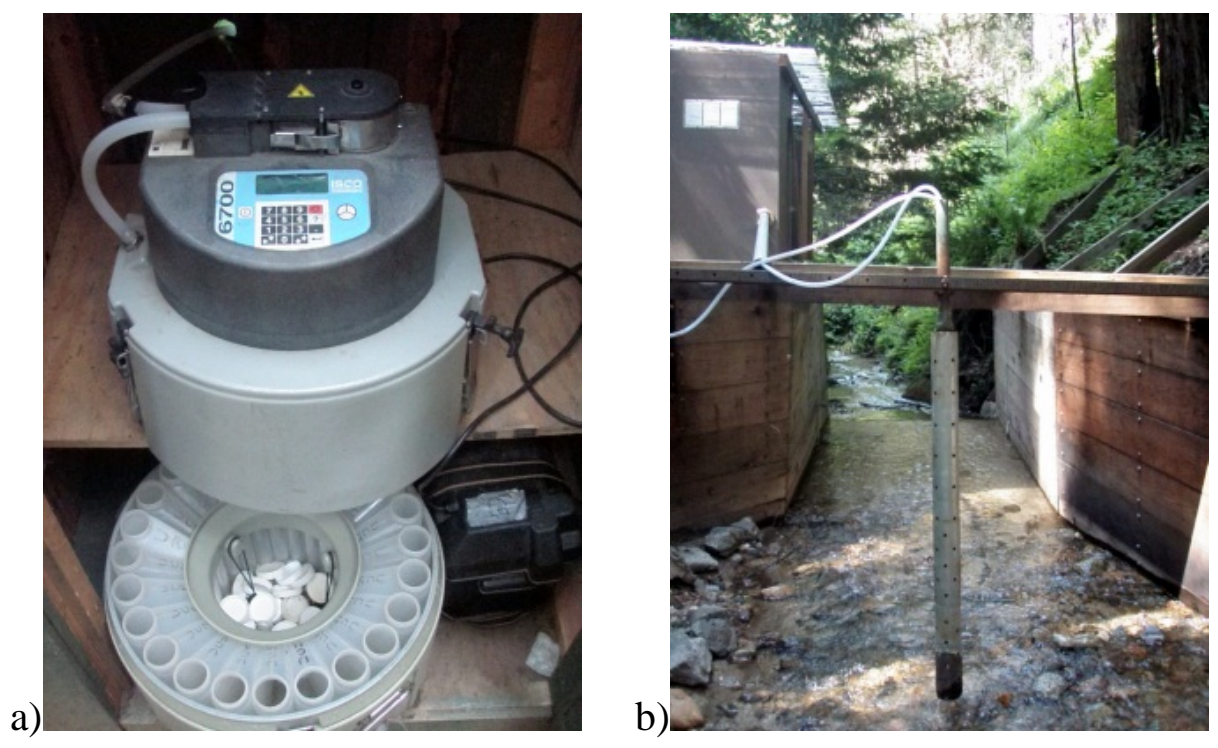

Figure 4-4. a) ISCO 6700 portable sampler; b) rated section flume, boom containing sampling tube at the North Fork monitoring station. 
Water samples were transported from the field to an on-site laboratory located on Swanton Pacific Ranch and processed for turbidity and SSC. Turbidity measurements were made by agitating the sample and pouring into vial that was run in $\mathrm{HACH}^{\circledR} 2100 \mathrm{AN}$ turbidimeter. Turbidity is a measure of the clarity of water and the higher amount of suspended solids results in a higher turbidity value, which is measured in Nephelometric Turbidity Units (NTU).

SSC analysis methods were adopted for the project following consultation with personnel at the USFS Pacific Southwest Research Station Redwoods Sciences Laboratory in Arcata, the USGS Water Laboratory in Marina, and other researchers. These methods were modified from ASTM D3977-97, Standard Test Methods for Determining Sediment Concentration in Water Samples, to follow procedures established by the Redwood Sciences Laboratory. All data from 2002-2006 were analyzed by Gaedeke (2006).

Due to the time demanding nature of the sampling process, protocols were established to minimize the number of samples run for SSC. A modified version of the turbidity threshold sampling (TTS) protocols used in the Caspar Creek Watershed Study was implemented using turbidity as a predictor of SSC (Lewis, 1996). Turbidity is measured for all samples and based on this sampling scheme, it was generally determined that samples with turbidity values below 20 NTUs would not be processed to determine SSC.

The beginning of storm events were defined at the start of rise of the stream stage. Sediment load calculations during a storm event were only calculated when turbidity was 
equal to or above 20 NTU. The end of the storm event was defined by when turbidity falls below $20 \mathrm{NTU}$ or the hydrograph intersects the $5.47 \times 10^{-4} \mathrm{cms} / \mathrm{km}^{2} / \mathrm{hr}(0.05$ $\mathrm{cfs} / \mathrm{mi}^{2} / \mathrm{hr}$ ) separation slope line, which starts at the point of initial increase of flow (Figure 4-5) (Hewlett and Hibbert, 1967; Gaedeke, 2006). When multiple peakflows occurred during a prolonged precipitation period storm events were separated if the peakflows on the hydrograph were at least 24 hours apart and the hydrograph had fallen to at least one half the level of the lesser of the two peaks (Gaedeke, 2006; Lewis et al., 2001).

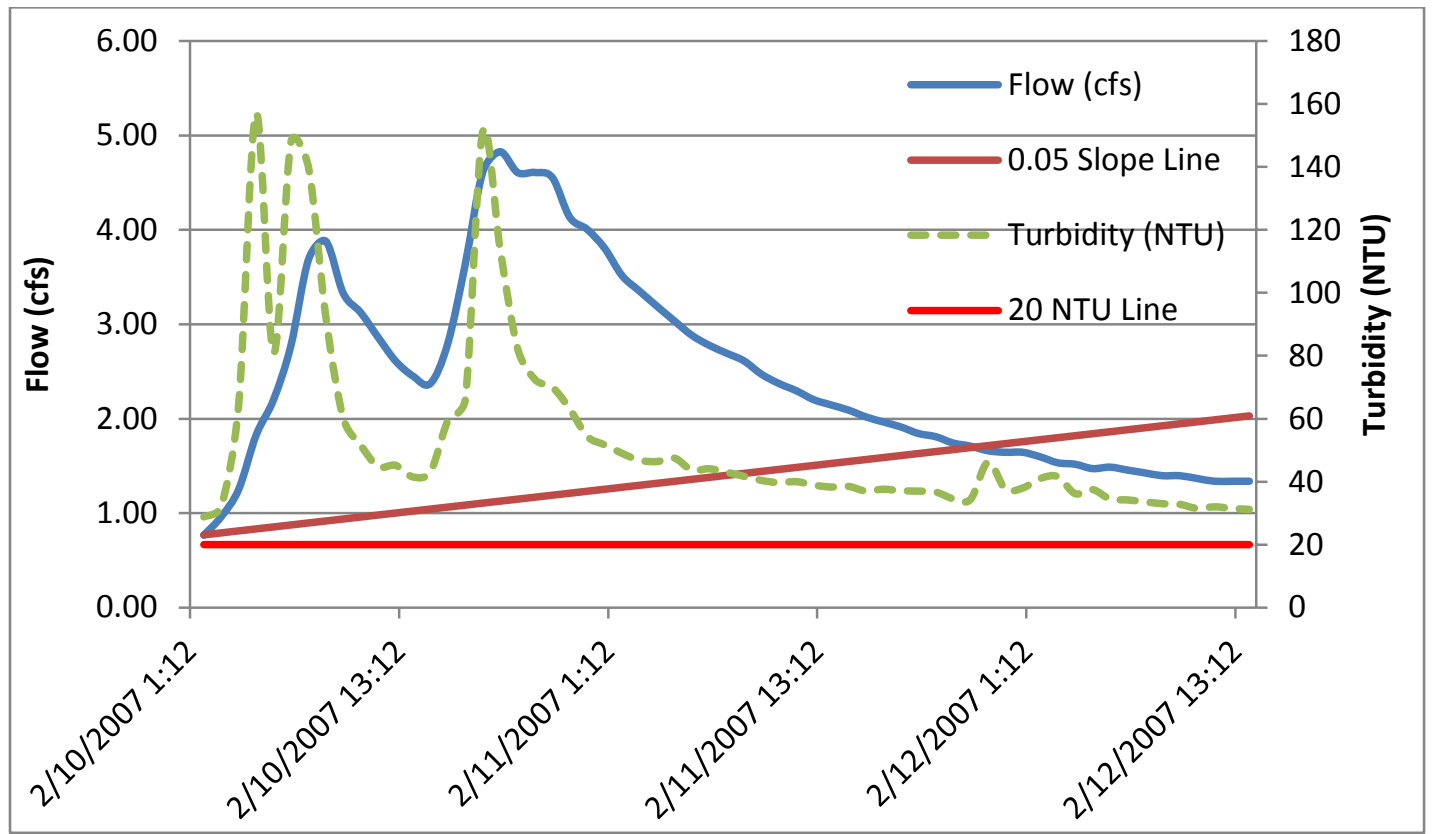

Figure 4-5. Example of storm event defined by 0.05 slope line intersecting hydrograph prior to turbidity falling below $20 \mathrm{NTU}$ at SF.

The sampling process involved filtering samples to determine the amount of sediment per sample, which can later be used to determine SSC (mg/L) for each sample and total sediment load $(\mathrm{kg})$ for each storm event. Specified bottles were processed by weighing the sample and noting bottle tare weight. Pre-weighed glass microfiber filters 
were placed on a filtering apparatus that had an electric pump that created a vacuum. Samples were then poured on to filters (higher turbidity requires more filters to be used for each sample) and the vacuum removed the water. Filters were oven dried, cooled, final weights are recorded, and any abnormalities were noted, such as presence of organic matter or larger particle size.

\section{$\underline{\text { Rainfall Data }}$}

The first rain gages were installed in 1997 at the "Red House" (RH) near the Little Creek and Scotts Creek confluence and at Landing 23 (LD) on the ridge above the confluence of the North and South Forks of Little Creek. An additional five rain gages were installed in 2002 at the ridge line of the General Smith redwood stand (RLSM), the ridge line of North Fork and South Fork on CEMEX property (RLNF, RLSF), the Al Smith House (AL), and near the Upper North Fork monitoring station (UNF). After the Lockheed Fire in 2009, an eighth rain gage site was established at the hillslope erosion plots site (HS) (Figure 3-3).

Each precipitation measurement location was equipped with a tipping bucket and manual National Weather Service (NWS) type rain gage located in open areas (Figure 46). Rainfall data is collected weekly using a Hobo ${ }^{\circledR}$ shuttle to download tipping bucket rain gages, while rainfall totals from manual rain gages were recorded in a field book. Tipping bucket gages record date and time of tip (approximately $0.25 \mathrm{~mm}$ or $0.01 \mathrm{in}$ ). Rain gages were downloaded weekly to ensure proper working condition to minimize the chance of failure during a storm event. Yearly maintenance included thorough cleaning of rain gages, calibration, and required battery and desiccant change. 


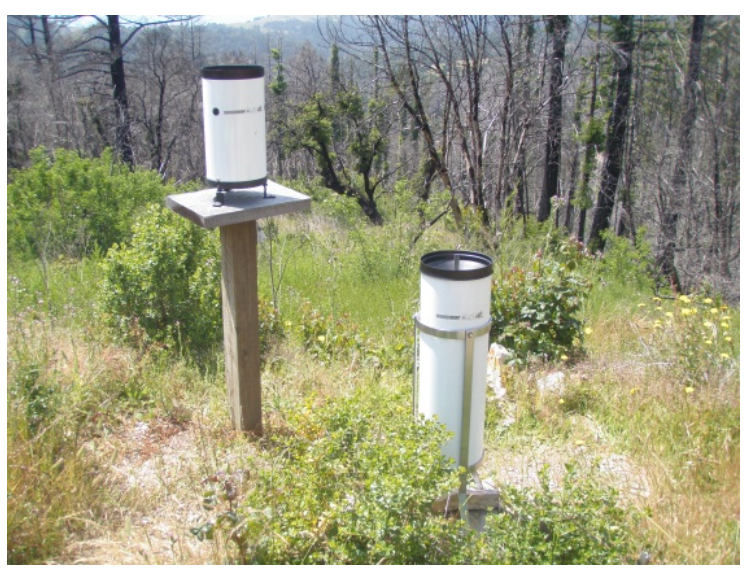

Figure 4-6. Tipping bucket (left) and manual NWS rain gages (right) at the Ridge line Smith station.

A rainfall data analysis conducted in 2007 found that the LD rain gage was representative of the entire watershed. This was determined by comparing the average precipitation characteristics from the LD rain gage to the weighted average of the other rain gages (Perkins, 2007). Unfortunately, the LD rain gage data was incomplete for the 2010 water year, so the UNF rain gage data was used as the primary rain gage for the study. Average precipitation at both UNF and LD rain gages are comparable, therefore LD data were used for incomplete years at UNF (Figure 4-7). This enabled consistent and continuous rainfall data for the entire study period. 


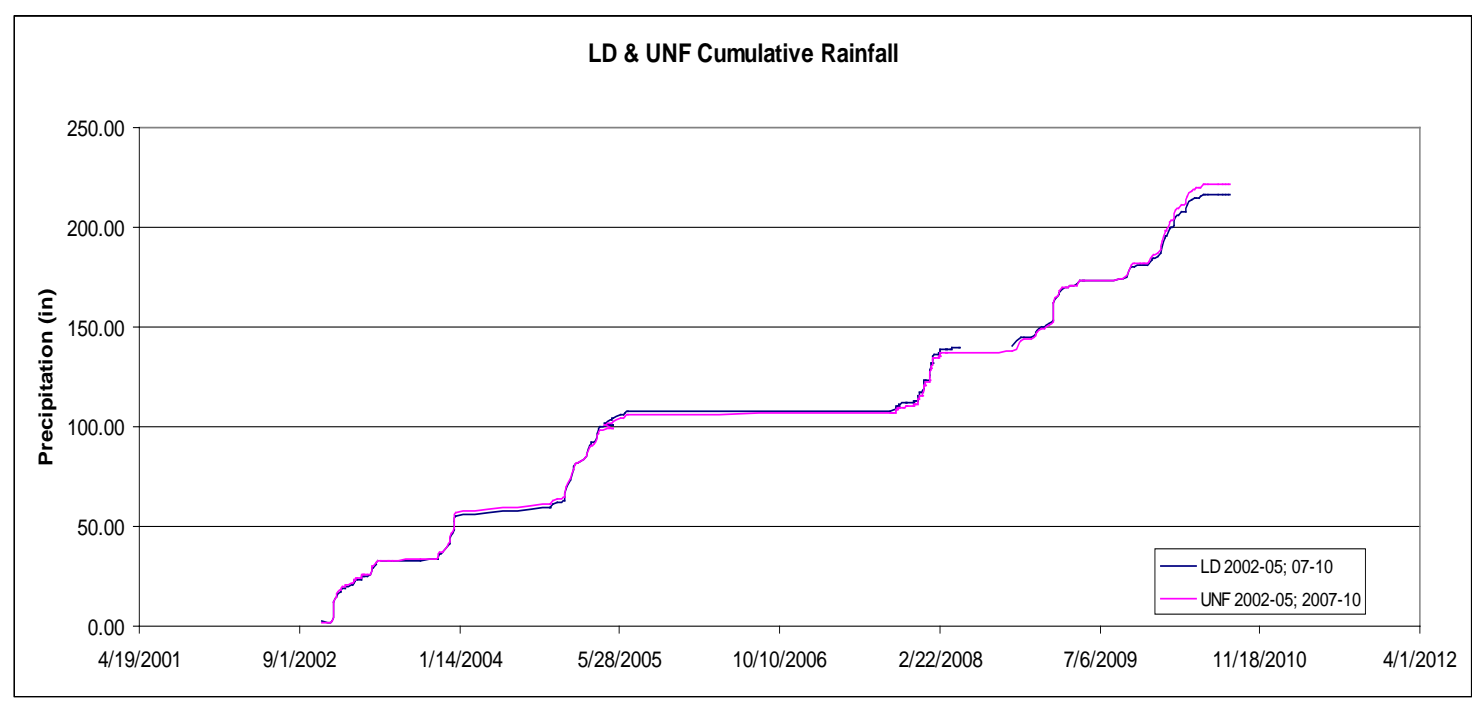

Figure 4-7. Cumulative precipitation for LD and UNF rain gages from 2002-2005, 20072010.

\section{Near-Stream Sediment Source Survey}

Near-stream sediment source surveys were conducted with the objective to identify and quantify the amount of sediment with direct stream channel contribution. Sediment source surveys were conducted in 2002, 2006, winter and summer of 2009, and 2010. The stream channels were divided into three segments in relation to the monitoring stations (Main Stem, North Fork, Upper North Fork) and each segment was further divided into 30.5 m (100 ft) reaches marked with rebar, tag, and flagging above the flood prone area. Surveys were conducted by traversing up the stream channel recording: location of erosional feature, volume of feature, estimated volume contributing to the stream channel, feature type, and contribution factor. Approximately $64 \%$ of the main channel was surveyed starting at the confluence of Little Creek and Scotts Creek, continuing up the North Fork, and ending at the property line just above the UNF monitoring station. 
Features with recent active erosion containing void volumes of 0.76 cubic meter (one cubic yard) and greater were recorded. Sediment sources identified in previous surveys or with volumes less than $0.76 \mathrm{~m}^{3}$ were not recorded unless a potential for greater contribution existed or additional sediment contribution occurred. The location of features were identified by stretching a $30.5 \mathrm{~m}$ (100 ft) cloth tape up the stream channel and noting stream reach name (MS, NF, UNF), reach number, right or left bank, and length of feature, as indicated on cloth tape. Features types were recorded by an acronym of the most common features encountered: eroded bank (EB), landslide (LS). Width, depth, and height were measured with tape measure or pocket rod to determine the volume of the feature. Since features were not normally uniform in volumetric shape, an estimate of the volume of sediment, along with consideration to the amount of sediment that directly contributed to stream channel, were noted. The contribution factor of either 'upslope’ or 'fluvial' was recorded along with other notes that helped identify and describe the sediment source.

\section{Post-Fire Data Collection}

With only a month and a half between the Lockheed Fire and the first storm event of the year, it was difficult to be fully prepared to collect post-fire data that would determine the watershed's response to this natural disturbance. As described above, suspended sediment data was collected during storm events following a substantial effort to repair damaged flumes and ensure that the monitoring equipment was in working order. Destroyed and damaged rain gages and infrastructure were replaced prior to the first post-fire winter. 


\section{Rainfall Simulator}

Rainfall simulations were performed at various burned and unburned locations in the Scotts Creek watershed to document watershed response to high intensity rainfall. Rainfall simulations have been used in post-fire setting to measure infiltration, runoff, erosion, and sediment yields in a number of studies (Pierson et al., 2003; BenavidesSolorio, 2003; Larsen et al., 2009). Rainfall simulations were conducted on a total of ten sites beginning in mid-October and ending mid-November 2009 (Figure 4-8). Five of these sites were conducted in Little Creek watershed with one control site in the lower watershed. The other five sites were in the greater Scotts Creek watershed with two control sites. Sites were chosen based on vegetation type, percent cover (leaf litter, live vegetation, and/or rock fragments), soil type and geology, percent slope, slope position, aspect, and soil burn severity. Out of the ten rainfall simulations, data was only recorded at eight sites as data recording protocol was being developed during the first two simulations. 


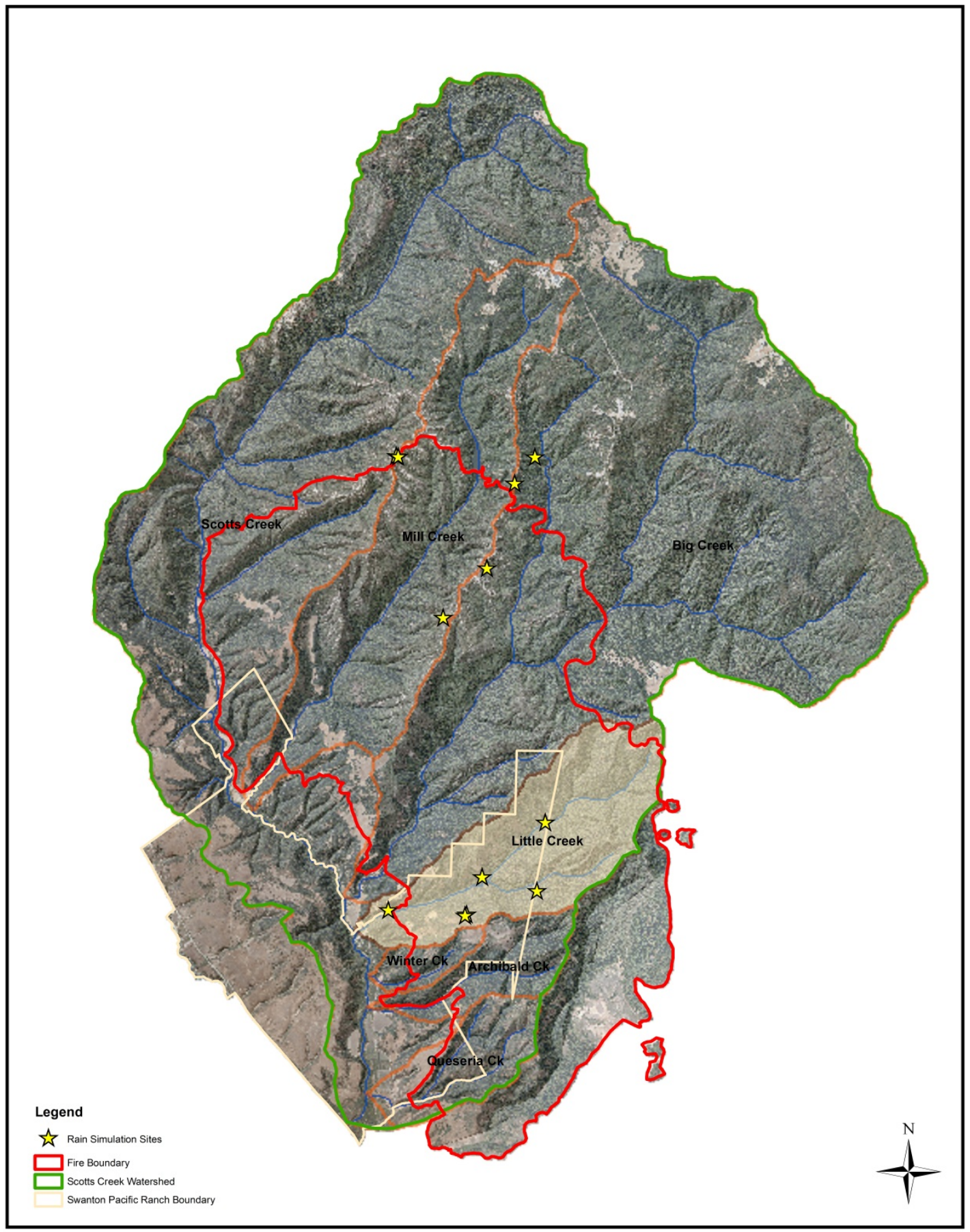

Figure 4-8. Rainfall simulation locations within Scotts Creek Watershed. 
A modified Purdue rainfall simulator was used to determine infiltration rates by applying simulated rainfall on a one square meter plot at a rate of approximately 51 $\mathrm{mm} / \mathrm{hr}$ (2 in/hr) (Figure 4-9). Plots were defined with three-sided sheet metal pounded into the soil. A catchment basin to collect surface runoff from the top 3-6 cm of soil was carefully inserted on the downslope end of the plots. The catchment basin had an affixed tube that drained all runoff to a bucket, where runoff was recorded at a regular interval (usually at 2 minute intervals). The rainfall simulator was constructed with a nozzle that swivels back and forth and had a controller that allows the user to adjust the rainfall rate. Each site was calibrated by raining on an one square meter metal catchment basin in which runoff was measured for 30 seconds increments; this value was then used in a runoff volume spreadsheet to calculate rainfall rate. The rainfall rate was adjusted until an approximate rate of $51 \mathrm{~mm} / \mathrm{hr}$ was achieved. The pressure was manually regulated to a specific amount to emulate the actual rain drops. A 189 liter (50 gal) barrel was used as the water source and it was transported to the different sites by truck. This amount of water allowed for simulations to run for 40 to 70 minutes, depending on the initial amount of water and the time required to calibrate the rainfall simulator. Simulations were started at approximately $51 \mathrm{~mm} / \mathrm{hr}$, but in some cases when the runoff rate was steady, the rainfall rate was increased. 


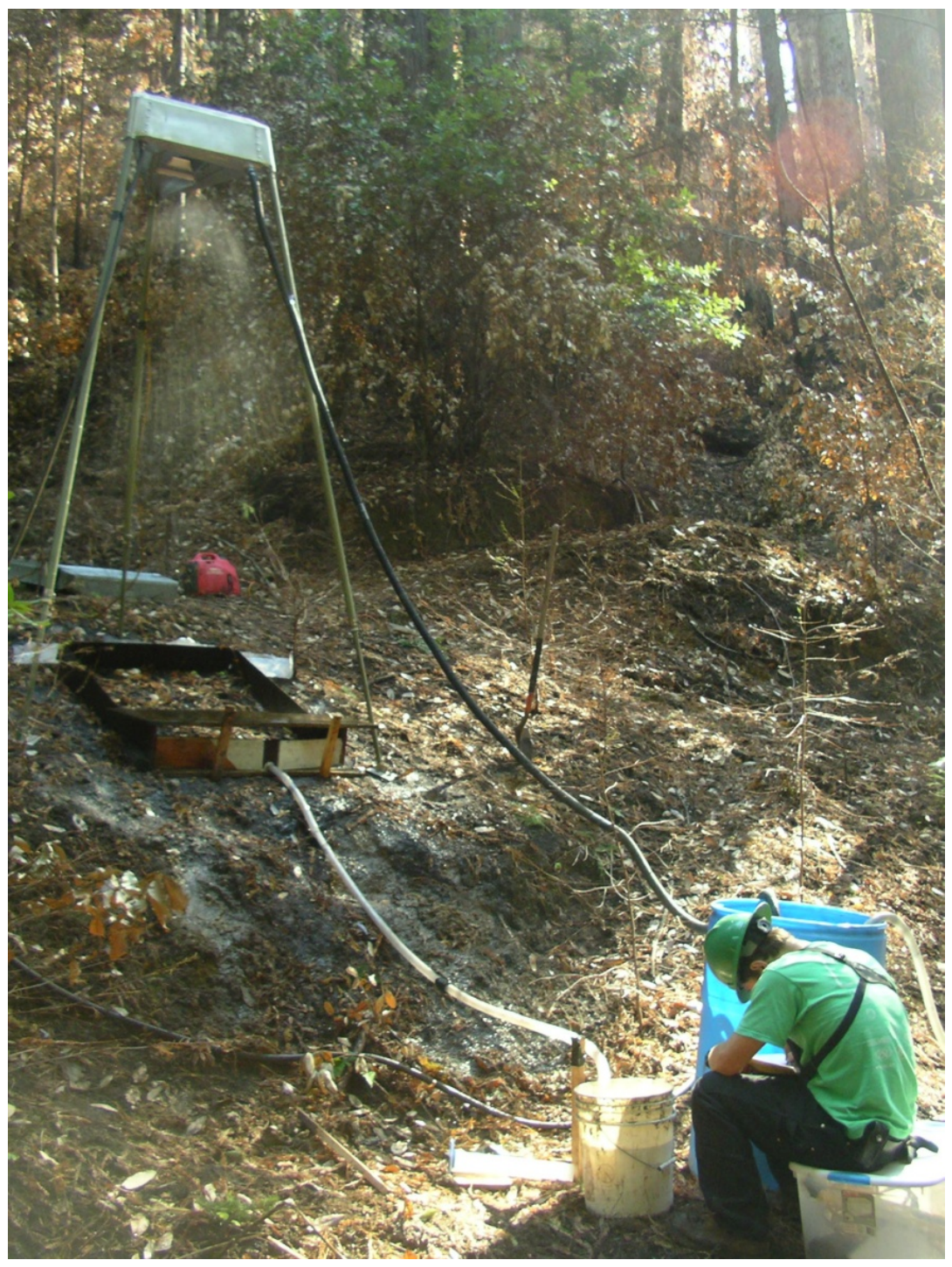

Figure 4-9. Rainfall simulator in use upslope of the UNF monitoring station.

\section{Hillslope Erosion Study}

Hillslope-derived erosion is common after a wildfire due to lack of ground cover, loss of shrub and overstory canopy interception, reduced soil infiltration due to soil sealing, and production of hydrophobic conditions (Benavides-Solorio and MacDonald, 2005; Ice et al., 2004; Larsen et al., 2009). One square meter plots were constructed in 
attempt to measure the amount of hillslope erosion in different slope classes. Plots were installed at Lions Flat, which is an area on the north facing slope of the South Fork of Little Creek. This area is located in a pocket of high burn severity in a transition zone of redwood to oak woodland. Plots were built using three beveled one meter wooden boards, with the downslope end containing a collection basin made from silt fence (Figure 4-10). The first nine plots were built on October 12, 2009, which was hours before first storm event of the season. An additional three plots were constructed in December 2009. Slope classes were 0-54\%, 55-74\%, 75\%+, with the steepest slope of 102\%. Hillslope plot basins were emptied during breaks between major storm events. Any organic matter in sediment basins were removed by hand and sediment was dried and weighed at the onsite laboratory.

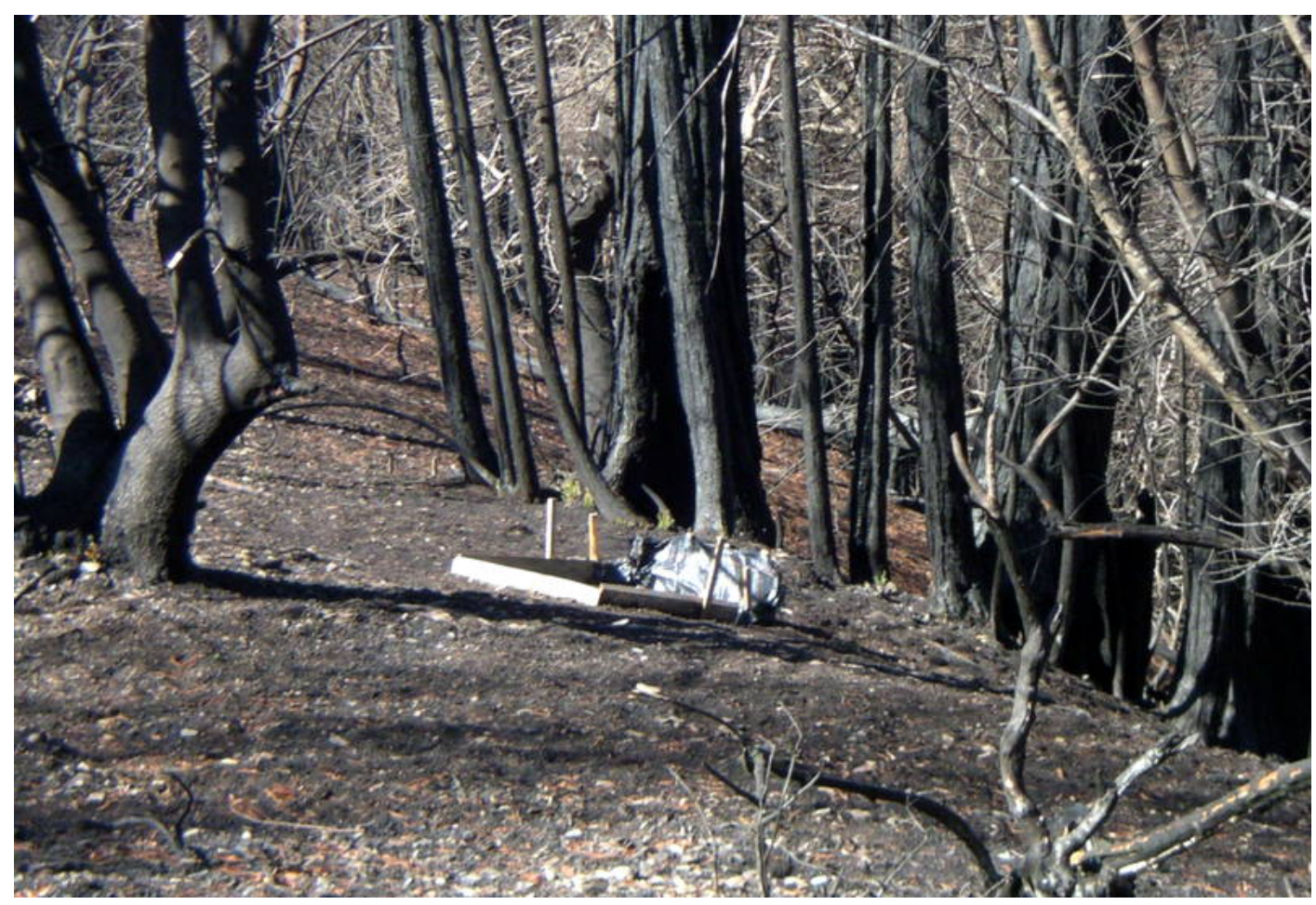

Figure 4-10. Hillslope erosion plot site at Lions Flat. 
At the time of installation, there was no live ground vegetation present within the plot boundaries. Rock fragments and leaf litter were present, but were not measured when the plots were installed. Throughout the storm season leaf litter increased due to wind and rain removing dead foliage from overstory trees. Live vegetation also began to grow with moist soils during the fall and winter period and with warmer spring temperatures. Percent ground cover consisting of rock fragments greater than $1.3 \mathrm{~cm}(0.5$ in), live vegetation and/or leaf litter, and bare soil were measured using a grid for each site following the last significant storm event of the first over-wintering period on March 11, 2010.

Hillslope erosion rates were also documented by installing sediment fences at various sites in Little Creek Watershed using techniques and methodology identified by Robichaud and Brown (2002). Three sediment fences were installed in small swales at forested sites with varying slopes and moderate burn severity. The two other sites were located near hillslope erosion plots for comparison of erosion rates. These sediment fences were installed in December 2009. Two sediment fences were installed in February 2010 in swales downslope from an area with a large network of rill erosion. Sediment fences were inspected following storm events to identify if any sediment accumulation occurred. The sediment accumulations were cleaned out at the end of the storm season, and dried and weighed in the lab.

\section{Soil Infiltration Tests}

Hydrophobicity tests were performed at 23 sites within the Little Creek watershed representing different vegetation types, soils, geology, soil burn severity, slope, and aspect (Figure 4-11). Tests were accomplished using Mini-Disc Infiltrometers (MDI) and 
Water Drop Penetration Time (WDPT) tests following a slight variation of procedures described by Robichaud et al. (2008). This procedure involved laying out a 30.5 m (100 $\mathrm{ft}$ ) transect along the slope contour and conducting a test every $6.1 \mathrm{~m}(20 \mathrm{ft})$ at approximately 1 and $3 \mathrm{~cm}$ depths. These tests were useful in determining if soils exhibited hydrophobic characteristics from the fire, which influences the amount of overland flow produced during a storm event. One site (site \#14) was a control (unburned) site on the lower slope of MS.

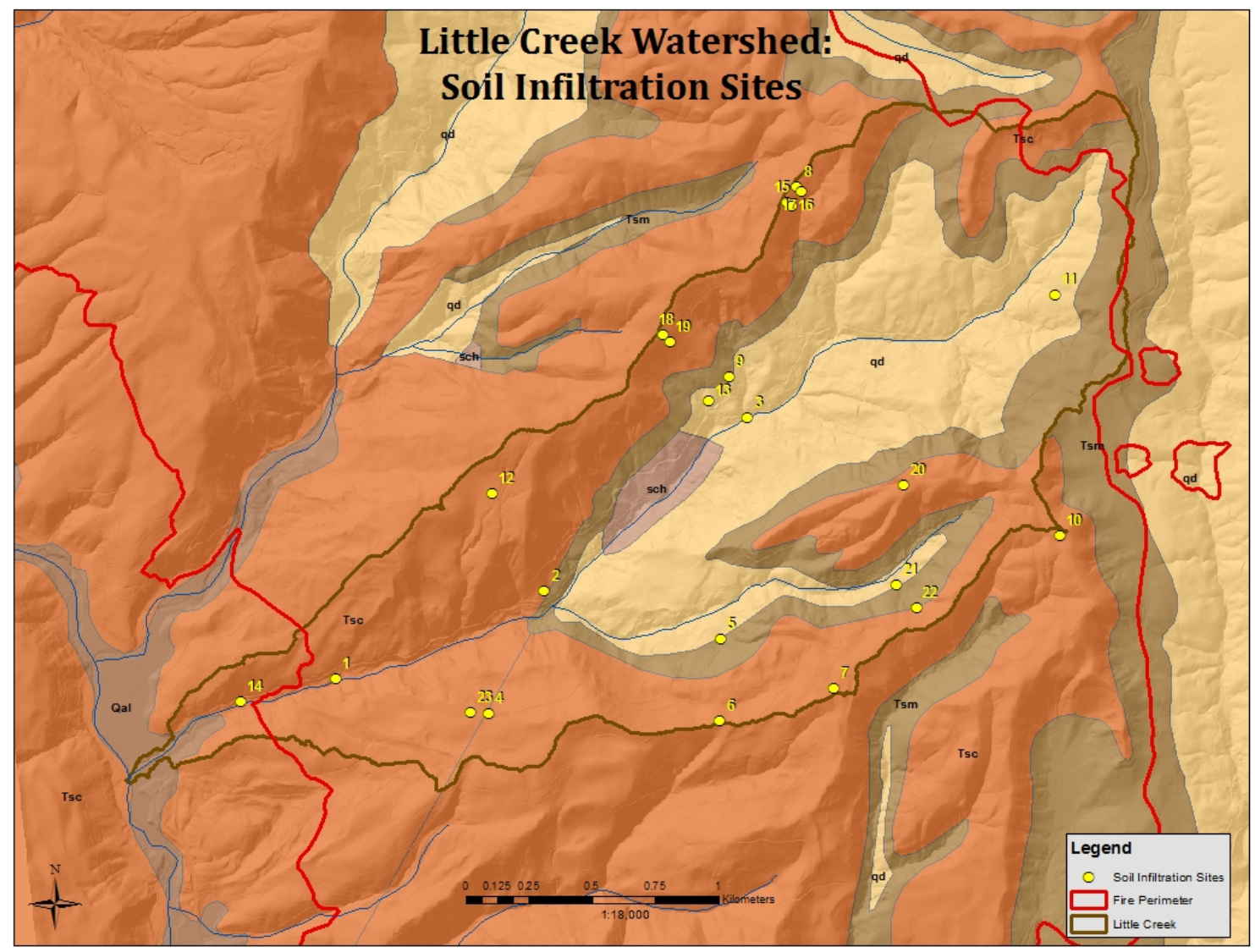

Figure 4-11. Soil Infiltration sites in Little Creek watershed.

Relatively flat benches were dug to the desired depth for each test in order to achieve accurate readings. Tests were not performed on the ground surface due to high infiltration rates when ash was present. Three measurements were taken at each depth for 
the MDI tests by placing the instrument on the soil for 30 seconds and reading the beginning and end volume of water in the instrument. WDPT tests were conducted similarly with benches dug to desired depth. One test was performed at each depth by placing a water drop on the soil and recording the time it took for the drop to infiltrate into the soil. Time was not recorded after 300 seconds (5 minutes) and " $300+$ " seconds was noted if no infiltration occurred. 


\section{CHAPTER 5}

\section{Data Analysis and Results}

\section{Data Analysis}

In order to understand the influence of wildfire on the Little Creek watershed, suspended sediment data, stage and flow data, and rainfall data were used to determine a change in event sediment load, suspended sediment concentration, and flow characteristics before and after the fire. Data analysis was conducted in two phases in order to fully understand the data set and results. The preliminary data analysis used a variety of statistical methods using Minitab® 16.0. Due to limitations in statistical software, an additional analysis was contracted to Mr. Jack Lewis, USFS Pacific Southwest Research Station Mathematical Statistician (retired), who performed statistical analyses using $\mathbf{R}$ language, an environment for statistical computing and graphics (R Development Core Team, 2010).

\section{$\underline{\text { Suspended Sediment Concentration }}$}

The first step in comparing SSC to flow was to review the data set to remove false readings caused by sampling errors and inaccurate stage readings. This analysis used instantaneous flow data; hourly sediment samples from three monitoring stations were used to derive SSC values, which were then paired with corresponding flow data. To further simplify or reduce the amount of data to optimize comparison, pre-fire data was only analyzed within same range of flow as post-fire data. This resulted in using data for flows less than or equal to $0.37 \mathrm{cms}(13 \mathrm{cfs})$ at the North Fork station, less than or equal to $0.65 \mathrm{cms}$ (23 cfs) at Upper North Fork, and less than or equal to $0.20 \mathrm{cms}(7.2 \mathrm{cfs})$ at 
the South Fork. Regression analyses were conducted on this data using Minitab ${ }^{\circledR} 16.0$ in the preliminary analysis. Fire was used as a dummy variable to determine if the SSC and flow relationship changed after the wildfire. Logarithmic transformations were conducted on both SSC and flow in order to normalize data.

Initial results from regression analysis indicated that the fire had a statistically significant effect on SSC/flow relationship for the NF and SF monitoring stations, while no significant difference at the UNF station (Table 5-1). The NF monitoring station found fire to have a negative overall effect $(p=0.001)$, meaning that SSC values were lower in relationship with flow after the fire. The SF station had a positive overall effect $(p=0.000)$, demonstrating that SSC was higher in relationship with flow after the fire. Though these results differ between monitoring stations, the overall results are inconclusive due to statistics indicating unexplained variance and autocorrelation.

Table 5-1. Regression analysis summary for SSC vs. flow with fire as dummy variable.

\begin{tabular}{|c|c|c|c|c|}
\hline Station & Regression equation & R-Sq(adj) & P-value (fire) & Durbin-Watson \\
\hline NF & $\begin{aligned} \log \mathrm{SSC}= & 1.70+0.433 \log \text { Flow }- \\
& 0.122 \text { Fire }\end{aligned}$ & $7.6 \%$ & 0.001 & 0.596 \\
\hline SF & $\begin{aligned} \log \mathrm{SSC}= & 1.30+0.665 \log \text { Flow }+ \\
& 0.173 \text { Fire }\end{aligned}$ & $17.8 \%$ & 0.000 & 0.418 \\
\hline UNF & $\begin{aligned} \log \text { SSC }= & 1.60+0.703 \text { log Flow }- \\
& 0.0385 \text { Fire }\end{aligned}$ & $20.9 \%$ & 0.466 & 0.637 \\
\hline
\end{tabular}

Severe positive serial autocorrelation in the residuals was present for all stations in this analysis, indicated by the Durbin-Watson statistic, ranging from 0.42 to 0.64 (Table 5-1). Several methods were used to address autocorrelation including separating rising and falling limbs, differencing (calculating the difference between pairs of 
observations at a time lag), comparing peak SSC versus peakflow, but low adjusted Rsquared values indicated that linear regression has unexplained variance. Since these results were unexpected based on similar past studies, recommendations were made to analyze the data using more powerful statistical programs, and this provided justification for adding the additional statistical analyses performed by Mr. Lewis.

Mann-Whitney non-parametric tests were utilized as an alternative method of identifying the difference between SSC before and after the wildfire, using different flow classes for each monitoring station. The results are summarized below:

- $\mathbf{N F}$ - Overall, fire has a negative effect on the SSC/flow relationship ( $\mathrm{p}=0.000$ ), while fire had negative effect below $0.20 \mathrm{cms}(7 \mathrm{cfs})(\mathrm{p}=0.000)$ and positive effect above $0.20 \mathrm{cms}(7 \mathrm{cfs})(\mathrm{p}=0.02)$.

- $\mathbf{S F}$ - Overall, fire has positive influence on SSC/flow relationship ( $\mathrm{p}=0.001$ ), with a strong effect at $0.08 \mathrm{cms}(3 \mathrm{cfs})$ and less $(\mathrm{p}=0.0001)$ and minimal significance at flows greater than $0.08 \mathrm{cms}(3 \mathrm{cfs})(\mathrm{p}=0.042)$.

- $\mathbf{U N F}$ - Fire has no influence on SSC/flow relationship ( $\mathrm{p}>0.05$ ) at all flow classes.

These results were not considered as the mean of points cannot be compared using the Mann-Whitney test because, like parametric tests, independent data are still required.

The secondary statistical analysis used a least squares regression model to test the relationship between SSC to instantaneous flow and antecedent rainfall. Treatment effects (fire, logging, salvage logging) were used as dummy variables for this model to 
determine their effect on the model. SSC and flow were transformed using natural logarithms. Initial regressions resulted in a large amount of unexplained variance.

Antecedent precipitation indices (APIs) were used to explain some of the unexplained variance. API is a number derived from precipitation data which can be used to estimate soil moisture levels. For this application, API was calculated using precipitation data that were summarized to hourly totals $\mathrm{P}_{i}$. The API with decay coefficient k was iteratively computed for hour $i$ as:

$$
\mathrm{API}_{k, i}=k \mathrm{API}_{k, i-1}+\mathrm{P}_{i}
$$

Models demonstrated significant positive autocorrelation in residuals at all monitoring stations. This causes underestimation in regression variance and can result in larger error rates. The autoregressive (AR) models in R's nlme package were used to describe serial autocorrelation in residuals. The continuous autocorrelation (CAR1) model, which is more flexible as it represents time by a continuous unequally spaced covariate, fits the SSC data best because the data contained many gaps between storm events.

\section{North Fork SSC}

The variance in $\log (\mathrm{SSC})$ without a treatment variable was best explained using $\log$ (flow) and the square root of the hourly API, with a decay coefficient of 0.85 (half-life $4.25 \mathrm{hr})$ :

$$
\log \left(S S C_{n f}\right)=2.153+1.023 \log \left(\text { flow }_{n f}\right)+1.202 \operatorname{sqrt}\left(\mathrm{API}_{0.85}\right)
$$


Results of the diagnostic plots revealed that the residuals were displaying severe serial autocorrelation and that an AR model of the order 1 could possibly describe the autocorrelation. The CAR1 error model was selected to address autocorrelation and resulted in the following generalized least squares model:

$$
\begin{gathered}
\log \left(S S C_{n f}\right) \sim 1.357+1.199 \log \left(\text { flow } w_{n f}\right)+1.173 \operatorname{sqrt}\left(\mathrm{API}_{0.85}\right)+0.153 \text { logging }-1.086 \text { fire } \\
-0.591 \text { logging } \mathrm{x} \operatorname{sqrt}\left(\mathrm{API}_{0.85}\right)+0.591 \text { fire } \mathrm{x} \operatorname{sqrt}\left(\mathrm{API}_{0.85}\right)
\end{gathered}
$$

The coefficients for this model are highly significant $(\mathrm{p}<0.0001)$ except in fire $\mathrm{x}$ $\operatorname{sqrt}\left(\mathrm{API}_{0.85}\right)(\mathrm{p}=0.075)$. The results of the model found that fire effects on NF SSC were significant and negative (SSC was lower in relationship to variables after the fire).

\section{Upper North Fork SSC}

The variance in $\log (\mathrm{SSC})$ without treatment variable was best explained using $\log ($ flow) and the square root of the hourly API, with a decay coefficient of 0.802 (halflife $5.5 \mathrm{hr})$ :

$$
\log \left(S S C_{\text {unf }}\right)=1.8506+0.7502 \log (\text { flow } \text { unf })+1.5454 \operatorname{sqrt}\left(\mathrm{API}_{0.802}\right)
$$

Additional terms involving treatment period were added to the model to test the effect of fire and the interaction between fire and sqrt(flow $\left.\mathrm{unf}_{\mathrm{f}}\right)$. The terms resulted in normallydistributed residuals and homogeneous variance, but significant serial autocorrelation in the residuals was present. The AR(4) (order 4) model was sufficient in describing the autocorrelation and resulting in the least squares model for $\mathrm{SSC}_{\mathrm{unf}}$ :

$$
\begin{aligned}
\log \left(S S C_{\text {unf }}\right) & \sim 1.555+0.801 \operatorname{sqrt}\left(\text { flow }_{\text {unf }}\right)+1.795 \operatorname{sqrt}\left(\mathrm{API}_{0.802}\right) \\
& -1.707 \text { fire }+0.741 \text { fire } \operatorname{xqrt}\left(\text { flow }_{\text {unf }}\right)
\end{aligned}
$$


With all coefficients of the model being highly significant $(\mathrm{p}<0.0001)$, the fire appeared to be associated with lower SSC, especially at lower flow and low API.

\section{South Fork SSC}

Similar to the NF and UNF stations, the variability in $\log (\mathrm{SSC})$ is best explained by sqrt(flow) and square root hourly API with a decay coefficient of 0.909 (half-life 7.3 $\mathrm{hr}$ ). The least squares model for SF SSC prior to accounting for fire is:

$$
\log \left(\mathrm{SSC}_{\mathrm{sf}}\right)=-0.420+1.512 \operatorname{sqrt}\left(\text { flow }_{\mathrm{sf}}\right)+2.109 \operatorname{sqrt}\left(\mathrm{API}_{0.909}\right)
$$

Although the plot of observed vs. fitted values (Figure 5-1) did not suggest change due to fire, the term fire $\mathrm{x}$ sqrt( flow $\left._{\mathrm{sf}}\right)$ was added to the model to test the effects of fire. The addition of this term resulted in homogeneous variance and significant autocorrelation in the residuals. The AR model to the order 3 eliminated autocorrelation at lags of 1 and 2, but does not fully describe the dependencies. The generalized least squares model chosen to represent SSC for the SF was:

$$
\begin{aligned}
\log \left(\mathrm{SSC}_{\mathrm{sf}}\right) \sim-0.661= & 1.551 \operatorname{sqrt}\left(\text { flow }_{\mathrm{sf}}\right)+2.279 \operatorname{sqrt}\left(\mathrm{API}_{0.909}\right)+0.354 \text { fire } \\
& +0.062 \text { fire } \mathrm{x} \text { sqrt }\left(\text { flow }_{\mathrm{sf}}\right)
\end{aligned}
$$

This model resulted in neither fire $(\mathrm{p}=0.31)$ nor the combined interaction with flow $(\mathrm{p}=$ 0.73) being statistically significant. 


\section{South Fork}

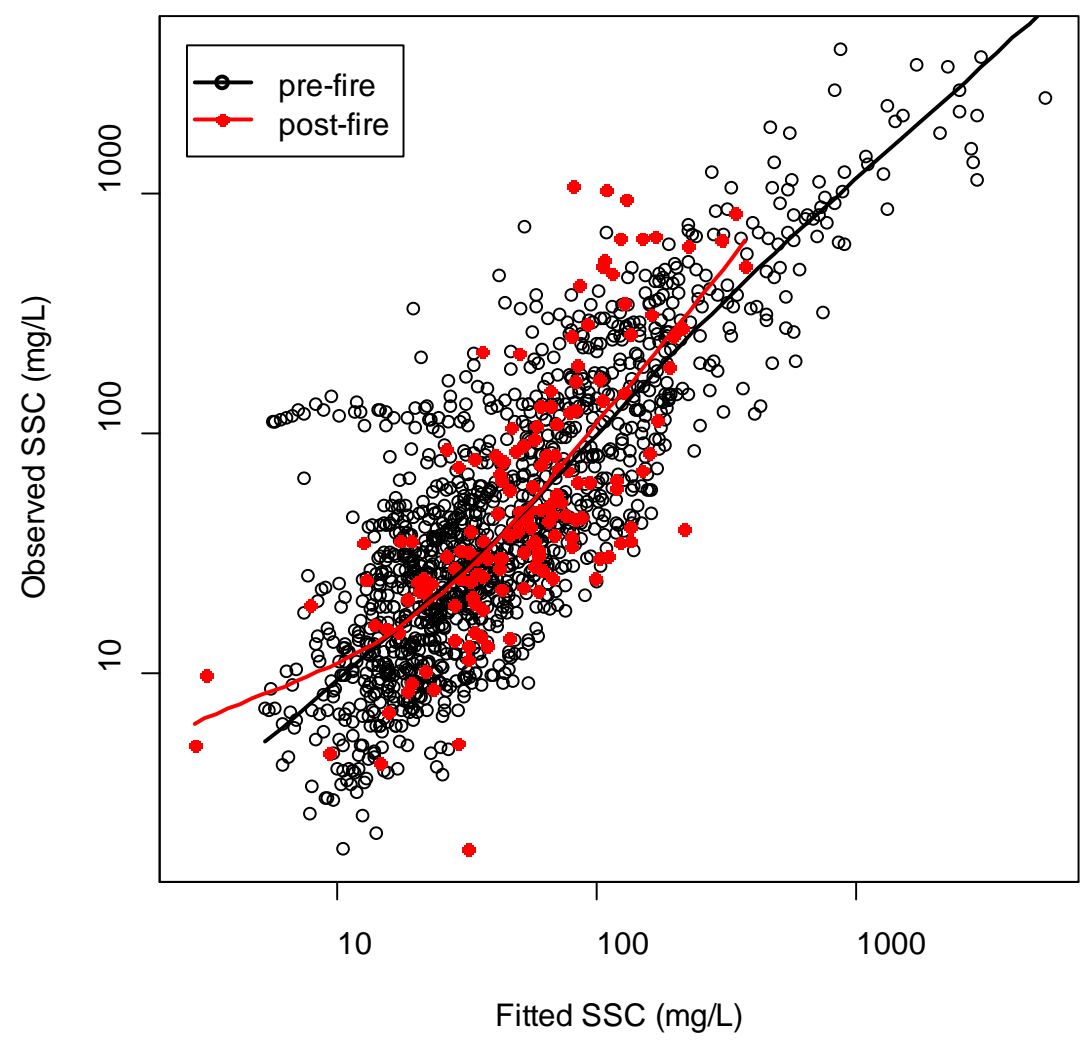

Figure 5-1. Fitted versus observed SSC values for South Fork.

\section{$\underline{\text { Event Sediment Load }}$}

Sediment mobilization and transportation during a given storm event is heavily influenced by rainfall characteristics (Spigel and Robichaud, 2007; Ryan et al, 2011; Benavides-Solorio and MacDonald, 2005). With the suspended sediment data and flow data from each station, the sediment load was calculated for each storm event for the seven years pre-fire and first year post-fire. Rainfall data from tipping bucket rain gages were processed using a program called RainRate written in Visual Basic for Applications in Microsoft Excel, created by Perkins (2007). This program calculates the following 
parameters for each storm: duration; end time; time since last storm; total precipitation; total storm energy; maximum intensity and time recorded for 15, 30, 60, 120, and 360 minute intervals; erosivity (EI) values for the 15, 30, 60, 120, and 360 minute intervals; and precipitation in previous 1, 3, 7, 10, 14, 28 day periods (Perkins, 2007).

Storm events are defined when less than 0.05 inches of precipitation occurs in a 6hour period. Once a storm event has ended as defined above, rainfall parameters are calculated for that storm event. Only storms with a minimum of 0.50 inches of precipitation are numbered and analyzed in this study.

The total storm energy (E) multiplied by the maximum rainfall intensity (I) at different time intervals make up what is called the R factor in the (Revised) Universal Soil Loss Equation, RUSLE. The R factor is a numerical value that quantifies the impact of a raindrop as well as the amount and rate of runoff likely to be associated with rain. The EI value was considered in this study because this value indicates how particle detachment is combined with transport capacity, and thus is an important factor in considering the relationship between sediment transport and precipitation on a watershed scale (Renard et al., 1997).

In order to analyze the effects of fire on the event sediment load and rainfall characteristics relationship, stepwise regression was conducted to determine which predictor variables were most influential to sediment load. After running multiple stepwise regressions for all three stations, the variables that were most consistently significant were EI30 (erosivity for 30-minute rainfall interval) and 28-day previous rainfall (measure of antecedent moisture conditions). A dummy variable for fire (1=post- 
fire, $0=$ fire) was used in order to see the influence of fire on event sediment load.

Logarithmic transformations for event sediment load were conducted to normalize the data (Table 5-2).

Table 5-2. Regression analysis summary for event sediment load vs. EI30, 28-day precipitation with fire as dummy variable.

\begin{tabular}{|c|c|c|c|c|}
\hline Station & Regression equation & R-Sq(adj) & $\begin{array}{c}\text { P-value } \\
\text { (fire) }\end{array}$ & $\begin{array}{l}\text { Durbin- } \\
\text { Watson }\end{array}$ \\
\hline NF & $\begin{array}{c}\text { Log NF event Load }=1.97+ \\
\odot .0643 \text { EI30 }+0.11528 \text {-day } \\
\text { Rain }-\odot .680 \text { Fire }\end{array}$ & $45.5 \%$ & 0.001 & 1.773 \\
\hline UNF & $\begin{array}{c}\text { Log UNF event Load }=1.30+ \\
0.0563 \text { EI30 }+0.11628 \text {-day } \\
\text { Rain }-0.178 \text { Fire }\end{array}$ & $28.1 \%$ & 0.485 & 1.819 \\
\hline SF & $\begin{array}{l}\text { Log SF event Load }=1.96+ \\
0.0592 \text { EI30 }+0.12528 \text {-day } \\
\text { Rain }-1.16 \text { Fire }\end{array}$ & $40.3 \%$ & 0.000 & 2.145 \\
\hline
\end{tabular}

NF and SF event sediment loads were significantly influenced by erosivity and 28-day previous rainfall amount. Fire also had a significant influence on sediment loads in relation to erosivity and previous rainfall, but in a negative manner, meaning that the influence of fire reduced sediment loads. As for UNF results, the p-value was well above 0.05 for fire, meaning that fire did not have a statistically significant influence on sediment production in relation to erosivity and 28-day previous rainfall.

Secondary statistical analysis used different methods to evaluate the influence of precipitation to storm event sediment load before and after treatment. The logarithms of stormflow volume and peakflow were used as predictors that resulted in higher R-squared values for all monitoring stations. The 28-day previous rainfall (amt28day) was a highly significant variable at NF ( $p=0.00004)$ and SF $(p=0.0004)$, while the logarithm of EI30 
was significant at UNF ( $p=0.008)$. These predictor variables accounted for 89 to $94 \%$ of the variance in storm event sediment load. The models used for evaluating fire effects and the results are provided below.

\section{North Fork}

In the following model all variables at NF were significant $(\mathrm{p}<0.0001)$ and linearly contributed to the model:

$$
\log \left(\operatorname{load}_{n f}\right)=-1.680+0.694 \log \left(\text { flow }_{n f}\right)+1.568 \log \left(\text { peak }_{n f}\right)-0.092 \text { amt28day }
$$

Diagnostics suggest that residuals were well-distributed except one outlier and faintly significant autocorrelation. The observed versus fitted values plot (Figure 5-2) show that pre- and post-fire observations were relatively similar. A Predictive Chow Test and the ANCOVA Chow Test are significant tests to determine whether or not two groups of data conform to the same regression model, or in this case whether post-fire data conforms with pre-fire data. The Predictive Chow Test showed a slightly significant fire effect $(\mathrm{p}=$ 0.048) and the ANCOVA Chow Test showed a significant fire effect $(\mathrm{p}=0.005)$.

Although these tests prove to be significant, when the outlier (Event \# 52) was removed neither test was significant (Predictive $\mathrm{p}=0.30$, ANCOVA $\mathrm{p}=0.069$ ). 
NF event loads

NF event loads (om
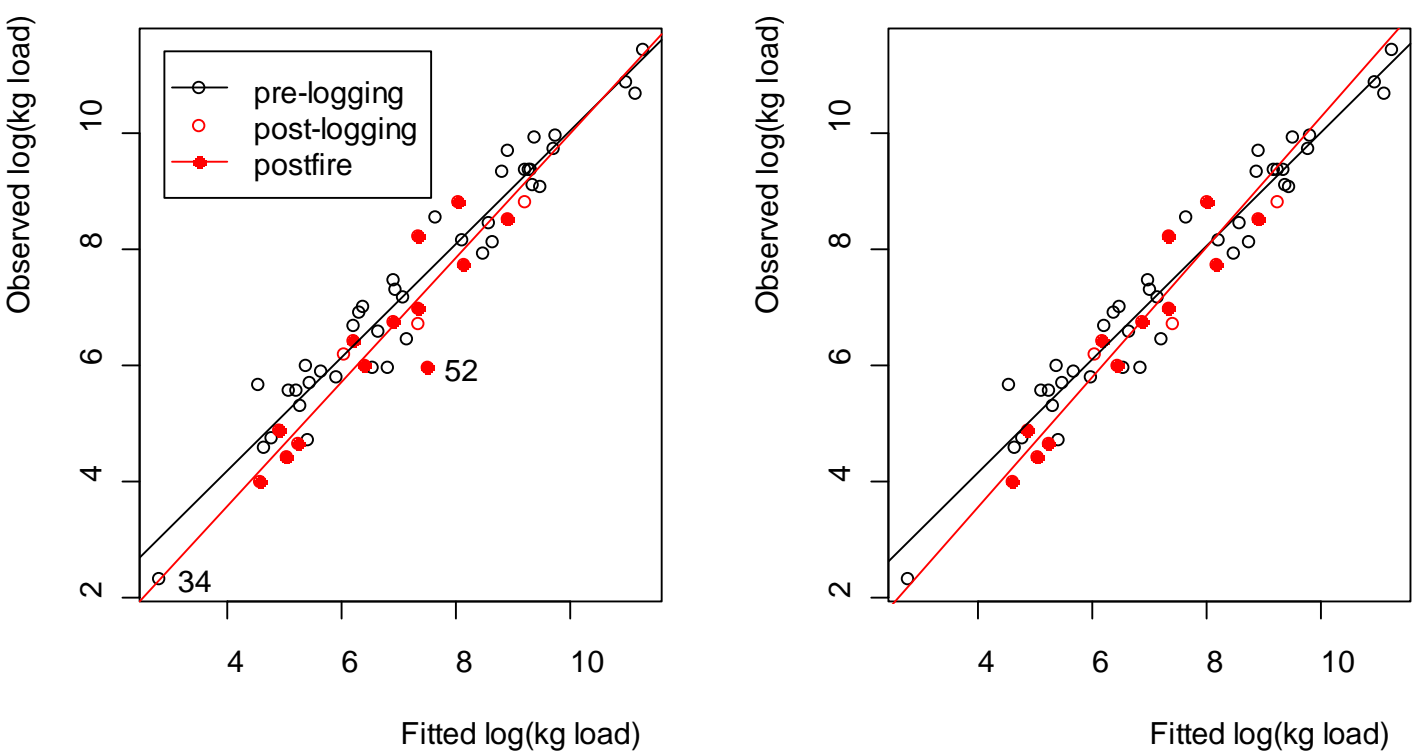

Figure 5-2. Observed versus fitted values for NF response to model. (Lewis, 2011).

\section{Upper North Fork}

All model variables were statistically significant $(\mathrm{p}<0.008)$ for the following model at UNF:

$$
\log \left(\operatorname{load}_{\text {unf }}\right)=-3.405+0.943 \log \left(\text { flow }_{\text {unf }}\right)+0.719 \log \left(\text { peak }_{\text {unf }}\right)-0.348 \log (\text { EI30 })
$$

Logarithmic transformations were effective in linearizing each variable's contribution to the model. Diagnostic plots show that residuals were well distributed, although some autocorrelation exists in lags 1 and 2. There was a slight difference between pre- and post-fire data, as displayed in the observed vs. fitted values plot (Figure 5-3). Both the Predictive Chow Test $(\mathrm{p}=0.59)$ and the ANCOVA Chow Test $(\mathrm{p}=0.61)$ do not suggest an effect of fire on event sediment loads. 


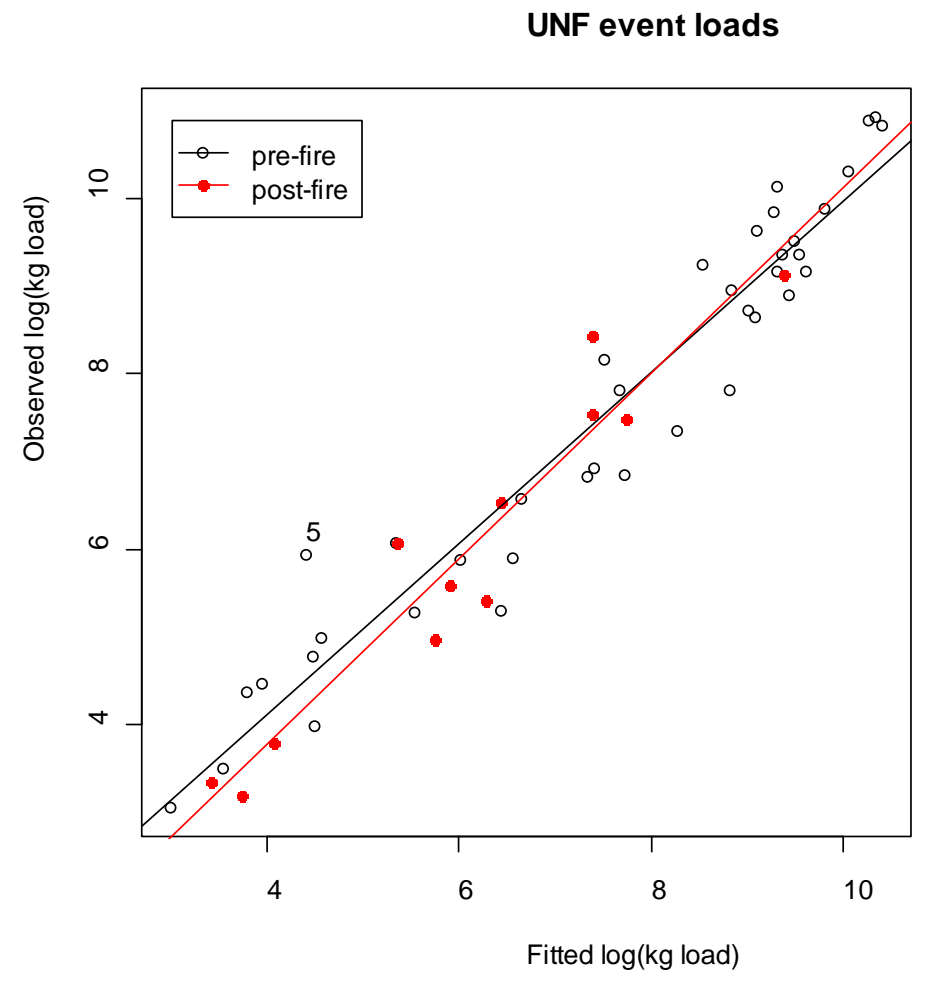

Figure 5-3. Scatter plot of observed versus fitted values for UNF response to model with regression lines displaying pre- and post-fire relationships (Lewis, 2011).

\section{South Fork}

The following model for sediment load at the South Fork showed all model variables to be statistically significant $(\mathrm{p}<0.0006)$ :

$$
\log \left(\operatorname{load}_{s f}\right)=0.017+0.519 \log \left(\text { flow }_{s f}\right)+1.980 \log \left(\text { peak }_{s f}\right)-0.118 \text { amt28day }^{\prime}
$$

While model variables had linear contributions to the model, diagnostic plots showed that the residuals were well-distributed and with no significant autocorrelation. There was a slight difference between pre- and post-fire observations, as presented in observed versus fitted values plot (Figure 5-4). The Predictive Chow Test $(\mathrm{p}=0.16)$ and ANCOVA Chow Test $(p=0.068)$ indicatde no significant fire effects respectively. Event 57 was the 
only post-fire event outside of pre-fire scatter as demonstrated in Figure 5-4. When this event was omitted both Chow test p-values were greater than 0.30 . With these results the conclusion is that there was no significant effect from fire.
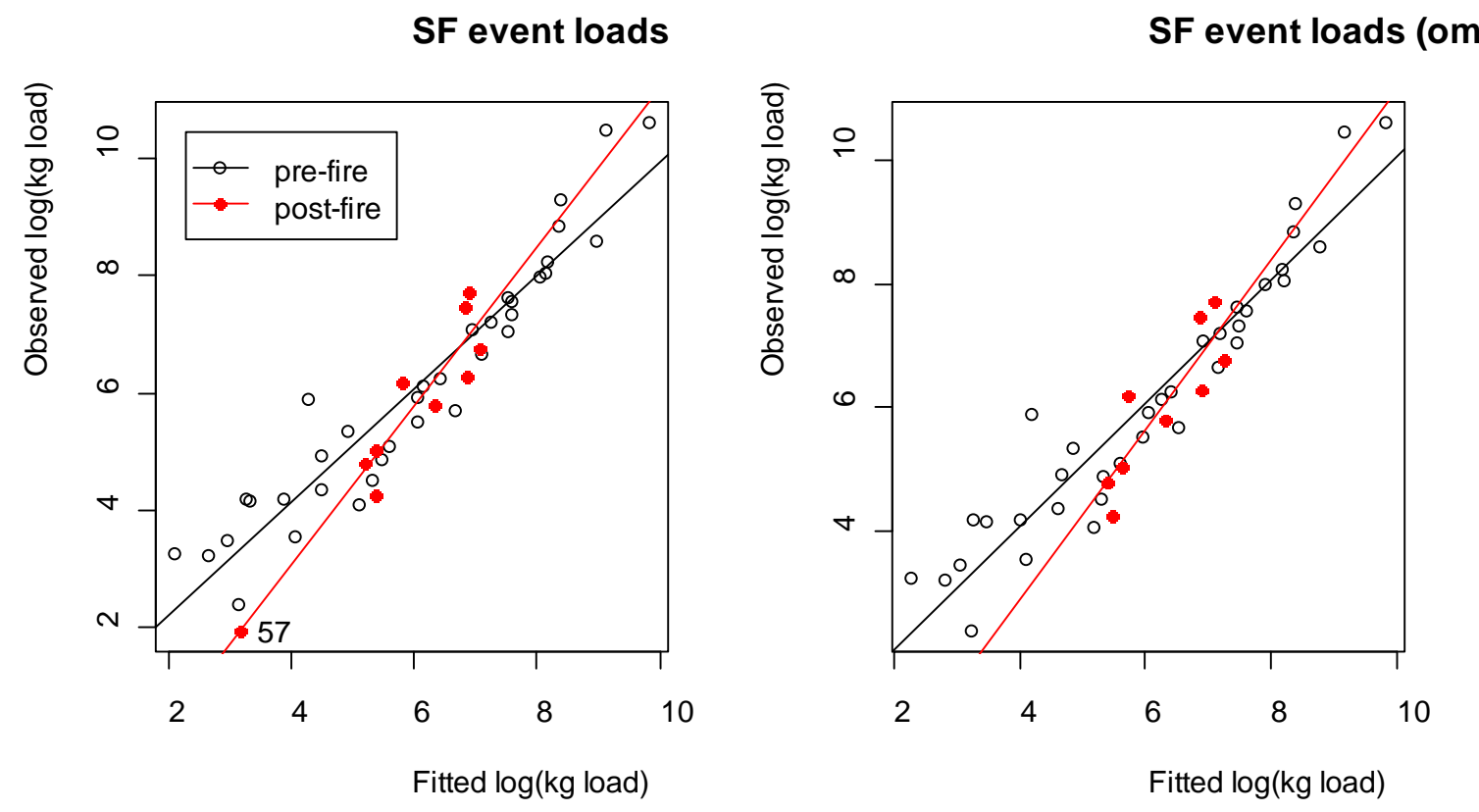

Figure 5-4. Scatter plot of observed versus fitted values for SF response to model with regression lines displaying pre- and post-fire relationships (Lewis, 2011).

\section{$\underline{\text { Stormflow Volume }}$}

An additional method to determine the influence of fire on the Little Creek watershed was to analyze stormflow volume. Stormflow volume was calculated for each event at each monitoring station. Event stormflow volume was used as response variable and event basin precipitation volume, 28-day previous rain (measure of antecedent soil moisture at beginning of storm), and fire were used as predictor variables. Logarithmic transformations were applied to both stormflow volume and basin precipitation to help with linearity and normality of residuals. 
NF and UNF results show that 28-day previous rain and basin precipitation volume had a significant influence on stormflow volume and fire had a significant negative influence to this relationship. SF also showed that 28-day previous rain and basin precipitation volume had significant influence on stormflow volume, but fire was not significant (Table 5-3).

Table 5-3. Regression analysis summary for stormflow volume vs. basin precipitation volume, 28-day precipitation with fire as dummy variable.

\begin{tabular}{|c|c|c|c|c|}
\hline Station & Regression equation & $\begin{array}{c}\text { R- } \\
\text { Sq(adj) }\end{array}$ & P-value (fire) & Durbin-Watson \\
\hline NF & $\begin{array}{l}\text { Log NF event stormflow }= \\
4.35+0.000003 \text { NF Basin } \\
\text { Precip }+0.093428 \text {-day } \\
\text { Rain }-0.312 \text { Fire }\end{array}$ & $51.7 \%$ & 0.026 & 1.676 \\
\hline UNF & $\begin{array}{l}\text { Log UNF event stormflow } \\
=-3.36+1.67 \text { Log UNF } \\
\text { Basin Precip }+0.0874 \\
28 \text {-day Rain }-0.463 \text { Fire }\end{array}$ & $55.6 \%$ & 0.003 & 1.424 \\
\hline SF & $\begin{array}{l}\text { Log SF event stormflow }= \\
-1.46+1.26 \text { Log SF } \\
\text { Basin Precip }+0.11128- \\
\text { day Rain }-0.211 \text { Fire }\end{array}$ & $48.8 \%$ & 0.197 & 1.861 \\
\hline
\end{tabular}

Stormflow volume was analyzed using the logarithm of precipitation depth and API as predictor variables in a secondary analysis. Precipitation depth is proportional to precipitation volume, therefore they can be used interchangeably. Using API rather than 28-day previous rainfall increased the R-squared value by 0.05 to 0.10 , therefore explaining more of the variability in the models.

\section{North Fork}

The following model was selected to evaluate the effects of fire on event stormflow volume: 


$$
\log \left(\text { flow }_{\mathrm{nf}}\right)=6.165+0.363 \mathrm{API}_{950 \mathrm{~d}}+1.794 \log (\mathrm{ppt})
$$

This model resulted in all variables being highly significant $(\mathrm{p}<0.0001)$ and that the predictors had strong linear contributions to the model. Residuals were well-distributed, except for one outlier and autocorrelation was minimally significant. The observed versus fitted values plot (Figure 5-5) shows that there is very little difference between pre-fire and post-fire observations. Both the Predictive Chow Test $(\mathrm{p}=0.65)$ and the ANCOVA Chow Test $(\mathrm{p}=0.22)$ indicate that the effect of fire was not significant.

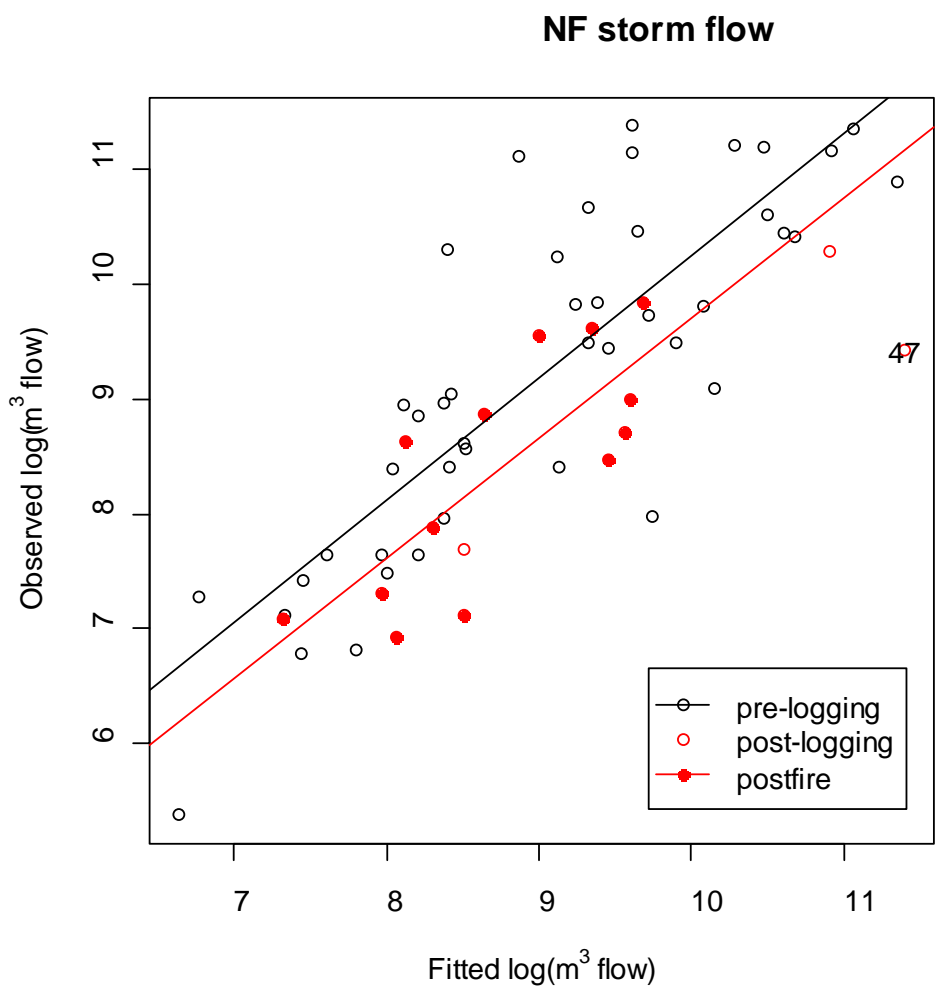

Figure 5-5. Observed versus fitted values scatterplot of the NF response to model for stormflow. 


\section{Upper North Fork}

The following model best represents the effect of fire on stormflow volume at UNF and had highly significant variables and strong linear contributions:

$$
\log \left(\text { flow }_{\text {unf }}\right)=6.117+0.386 \mathrm{API}_{935 \mathrm{~d}}+1.928 \log (\mathrm{ppt})
$$

Autocorrelation was present in several lags and the Durbin-Watson statistic (1.26) indicates autocorrelation was significant $(\mathrm{p}=0.002)$. The predictive Chow Test and the ANCOVA test differed on the significance of the effects of fire, with the Predictive Chow test indicated non-significance $(\mathrm{p}=0.45)$ and the ANCOVA was marginally significant $(\mathrm{p}=0.03)$. The observed versus fitted values plot showed slightly smaller postfire flow volumes than pre-fire volumes (Figure 5-6). An ARMA(1,2) error model was fitted after a dummy variable for fire was added to the model. This resulted in eliminating autocorrelation up to lag 9. This resulted in the fire coefficient being not significant $(p=0.68)$. 


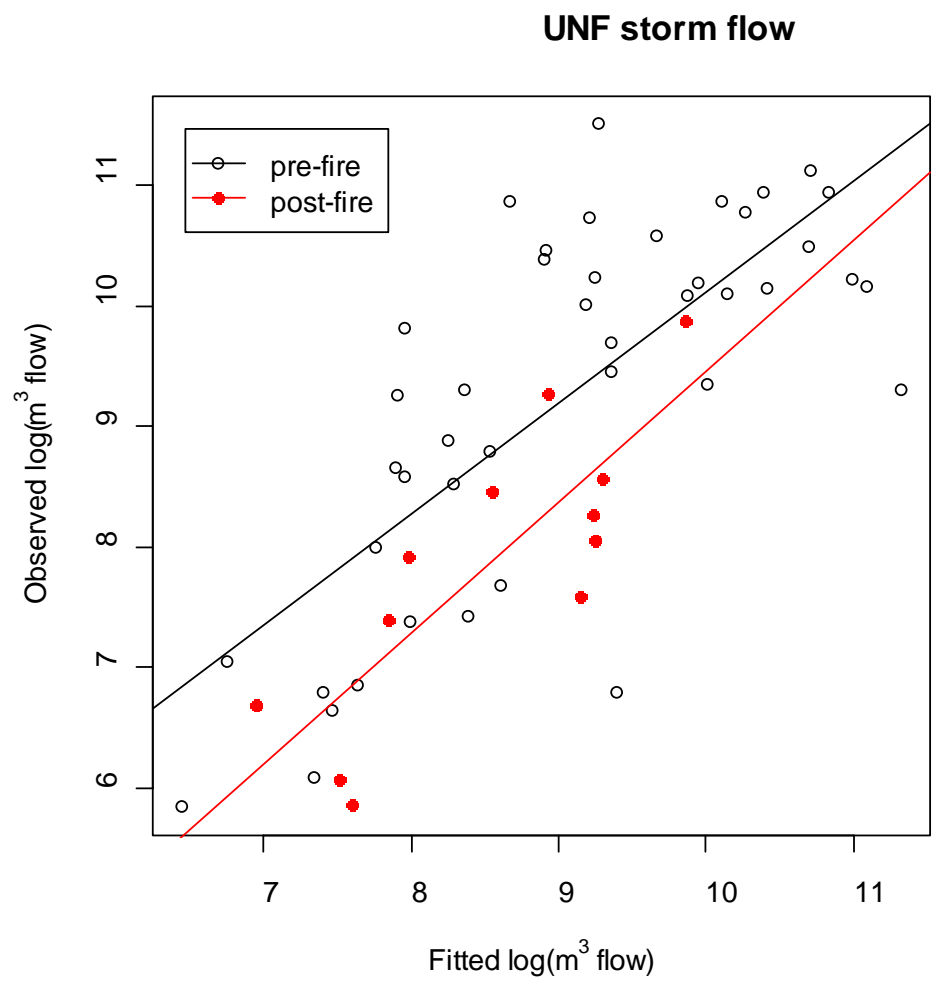

Figure 5-6. Observed versus fitted values scatterplot of the UNF response to model for stormflow.

\section{South Fork}

The South Fork model had highly significant variables $(\mathrm{p}<0.0001)$ and strong linear contributions from both predictors:

$$
\log \left(\text { flow }_{\mathrm{sf}}\right)=4.940+0.343 \mathrm{API}_{970 \mathrm{~d}}+1.565 \log (\mathrm{ppt})
$$

A few outliers were present in the diagnostic plots but there was no significant autocorrelation. The Predictive Chow Test $(\mathrm{p}=0.16)$ and ANCOVA test $(\mathrm{p}=0.17)$ indicated no significance to the effects of fire. The observed versus fitted values plot indicates that there was no effect of fire beyond outlier event 57 (Figure 5-7). When this 
outlier was removed, the p-values (Predictive Chow Test and ANCOVA test) changed to 0.71 and 0.37 , resulting in no fire effect on SF flow volumes.

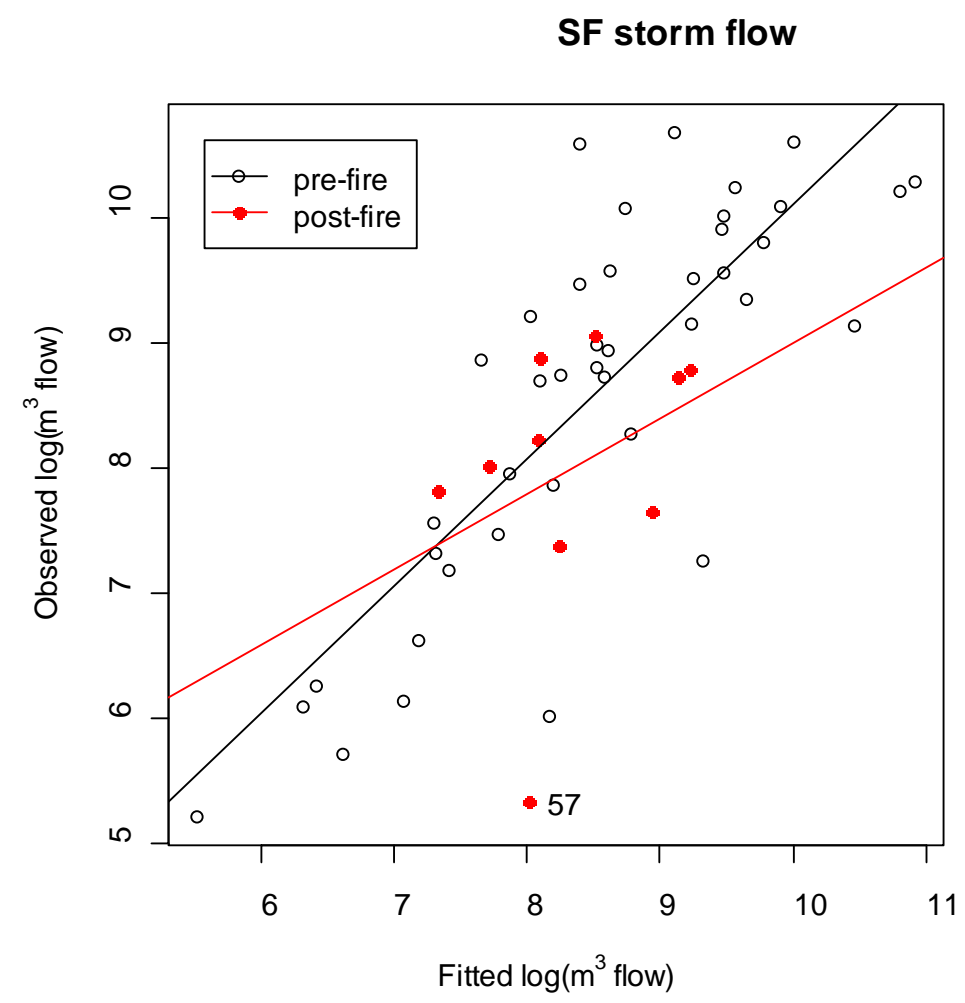

Figure 5-7. Observed versus fitted values scatterplot of the SF response to model for stormflow.

\section{Sediment Source Survey}

The first near-stream sediment source survey in Little Creek was conducted in September 2002. The Main Stem, North Fork, and South Fork were surveyed up to the Swanton Pacific Ranch property line. The South Fork sediment survey was only performed in 2002 and therefore was not considered in this thesis. 
A vast number of features were identified in the 2002 survey, as would be expected in the inaugural survey, and identified 54 and 53 sediment sources over $0.76 \mathrm{~m}^{3}$ $\left(1 \mathrm{yd}^{3}\right)$ on the Main Stem reach and North Fork reaches, respectively (Table 5-4). This survey resulted in the most features and the total calculated volume was more than a magnitude higher than recorded in the surveys that followed (Figure 5-8). The majority of the features identified were bank erosion from fluvial activity.

Table 5-4. Summary of near-stream sediment surveys for each year and reach. EB= eroding bank, LS = landslide.

\begin{tabular}{|c|c|c|c|c|c|}
\hline \multicolumn{7}{|c|}{ Total Calculated Volume } \\
\hline \multirow{3}{*}{ Year } & Stream & \# of features & EB/LS & m$^{\mathbf{3}}$ & yd $^{\mathbf{3}}$ \\
\hline 2002 & MS & 54 & $45 / 9$ & 5982.1 & 7824.3 \\
\cline { 2 - 6 } & NF & 53 & $35 / 18$ & 6719.3 & 8788.6 \\
\hline 2006 & MS & 20 & $18 / 2$ & 181.5 & 237.5 \\
\cline { 2 - 6 } & NF & 29 & $19 / 0$ & 201.2 & 263.1 \\
\hline 2009 & MS & 16 & $9 / 5^{*}$ & 78.7 & 103.0 \\
\cline { 2 - 6 } & NF & 3 & $3 / 0$ & 9.9 & 13.0 \\
\hline 2010 & MS & 11 & $7 / 2^{*}$ & 38.2 & 50.0 \\
\cline { 2 - 6 } & NF & 8 & $7 / 1$ & 11.7 & 15.2 \\
\hline
\end{tabular}

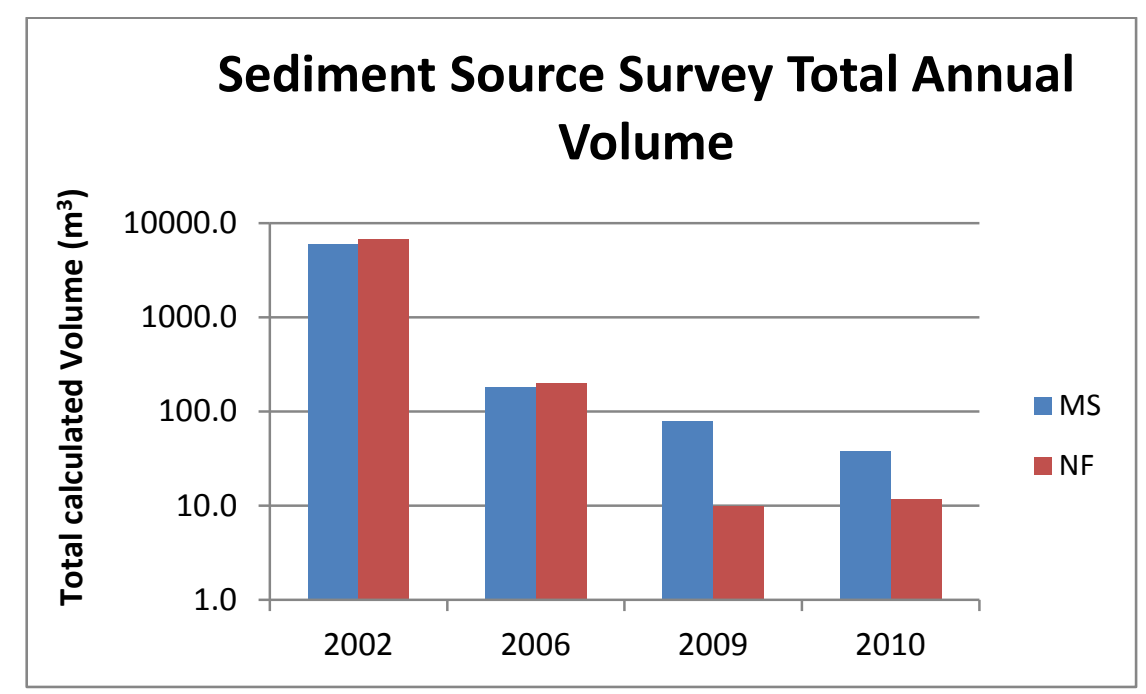

Figure 5-8. Annual total calculated volume for each near-stream sediment survey. 
The sediment survey completed in 2006 identified a lower number of new contributing sources. MS had 20 new contributing features; two were landslides and the remainder were classified as eroding bank features. NF had 29 new contributing features, all of which were from bank erosion.

Two surveys were performed in 2009, one during a break between storms midwinter and the other at the end of the storm season. The results from the 2009 survey noted that many of the sediment sources from previous sediment source surveys (2002, 2006) were still active and contributing sediment to the channel. The majority of new sediment sources were relatively small (less than $306 \mathrm{~m}^{3}$ or $400 \mathrm{ft}^{3}$ ). Eroded banks were most commonly observed in the watershed and landslides were less frequently noted. The contributing factors for sediment sources were mainly fluvial and upslope disturbances. The upslope disturbances resulted from numerous factors, generally downed trees related to windthrow and human and/or animal activity (debris cleared from roads, trails, etc.).

In 2010 two surveys were conducted, one mid-winter and one in June after all significant storm events had occurred. The 2010 sediment survey was the first survey following the wildfire, new sediment sources were identified that were induced by the fire such as upslope dry ravel, and landslides from fallen trees. Eleven new sources were identified on MS and eight features on NF, with eroding banks being the dominate feature. Total calculated volume was half as much as was recorded in the 2009 survey on MS and only slightly more than 2009 survey on NF. 


\section{$\underline{\text { Post-Fire Data }}$}

In an attempt to understand the effects of fire on a watershed scale, many efforts were made to collect data including hillslope erosion, rainfall simulations, and soil infiltration tests. These studies along with field observations were analyzed as supporting information in documenting on how a coastal forested watershed responds to wildfire.

\section{Rainfall Simulator}

Rainfall simulations were performed at nine sites in 2009 throughout the Scotts Creek watershed a few months following the fire. The initial site, located in an area with high soil burn severity near the Lions Flat hillslope erosion study site, was a trial run with the rainfall simulator. Runoff data had a large margin of error and was not analyzed. Of the remaining eight sites, half were in the Little Creek watershed, including a control site on an unburned hillside. The other half of the sites were located in the Upper Scotts Creek, Big Creek, and Mill Creek basins (Figure 3-1), with one burn site and a corresponding unburned control site.

In order to obtain the runoff rate, the recorded bucket depth at each interval was converted to volume using following formula:

$$
\begin{aligned}
& \text { Runoff Volume }(\mathrm{L})=0.009712 * \mathrm{BD}^{2}+(1.377 * \mathrm{BD}) \\
& \text { where: } \mathrm{BD}=\text { bucket depth in centimeters. }
\end{aligned}
$$

Runoff volume and simulated rainfall were plotted with time and a regression line was added to the runoff volume to display changes in runoff rates (Figure 5-9; Appendix D). Infiltration rate was calculated for each site by subtracting the runoff rate from the 
rainfall rate. Hydrologic response or the runoff to rainfall ratio was calculated by dividing the total runoff by total rainfall (Table 5-5).

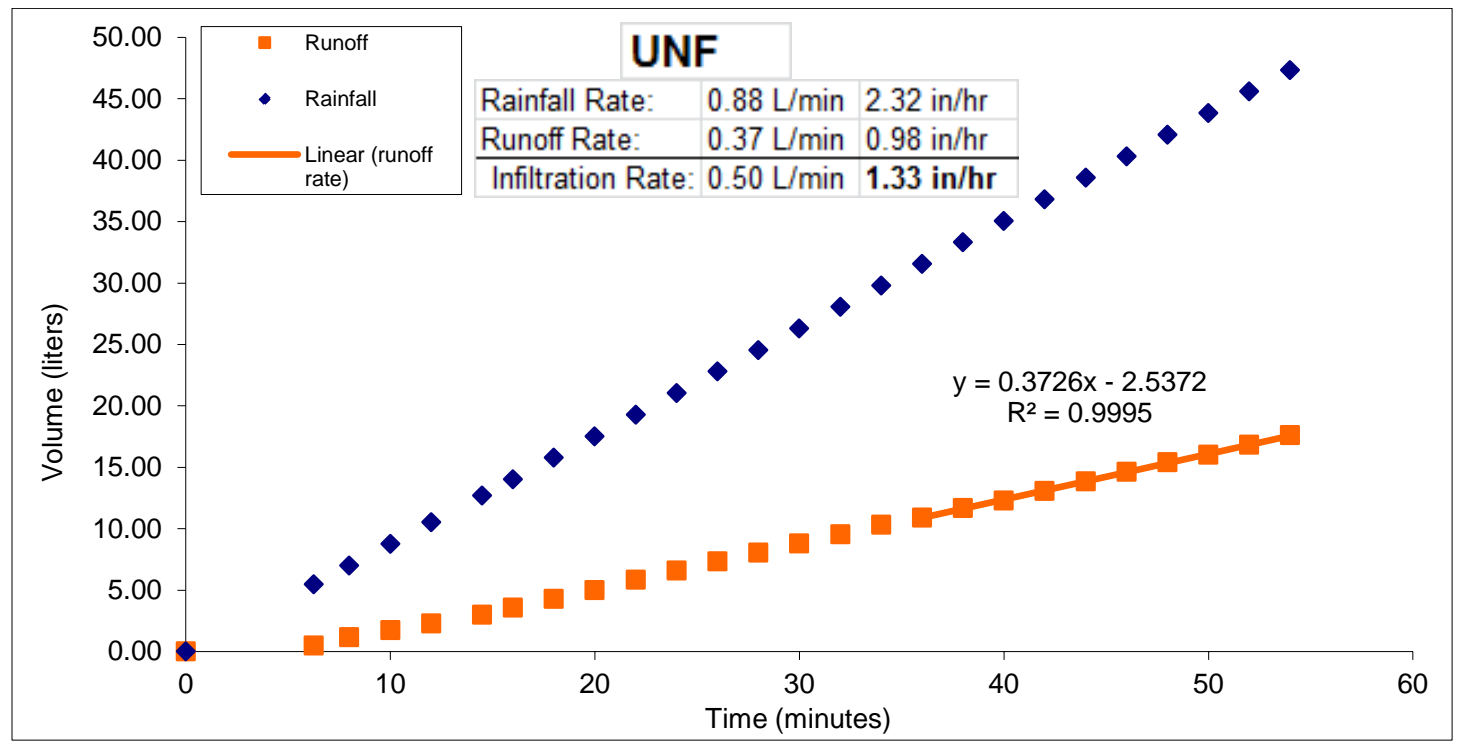

Figure 5-9. Rainfall and runoff plot for rainfall simulation at the Upper North Fork site.

Table 5-5. Infiltration rate and hydrologic response for rainfall simulator sites.

\begin{tabular}{|l|r|r|r|}
\hline \multicolumn{1}{|c|}{ Site } & $\begin{array}{c}\text { Infiltration } \\
\text { Rate (mm/hr) }\end{array}$ & $\begin{array}{c}\text { Infiltration } \\
\text { Rate (in/hr) }\end{array}$ & $\begin{array}{c}\text { Hydrologic } \\
\text { Response }\end{array}$ \\
\hline $\begin{array}{l}\text { Lower Little Creek } \\
\text { Unburned }\end{array}$ & 59.69 & 2.35 & 0.11 \\
\hline Mill Creek Ridge Unburned & 53.59 & 2.11 & 0.11 \\
\hline Penstock unburned & 4.83 & 0.19 & 0.83 \\
\hline Little Creek Cabins & 7.62 & 0.30 & 0.34 \\
\hline $\begin{array}{l}\text { Upper North Fork Little } \\
\text { Creek }\end{array}$ & 33.78 & 1.33 & 0.37 \\
\hline South Fork Little Creek & 75.95 & 2.99 & 0.14 \\
\hline Penstock Burned & $-1.27 *$ & $-0.05^{*}$ & 0.82 \\
\hline Boyer Creek Ridge & 8.13 & 0.32 & 0.70 \\
\hline
\end{tabular}

*Negative infiltration rate due to high runoff rate at end of test.

Sites on the ridges with shallow soils and mudstone parent material had the lowest infiltration rates and highest hydrologic response. The Penstock burned site was one of 
the ridge sites, and despite the negative infiltration rate, the hydrologic response was substantial. The negative infiltration rate recorded was due to the high runoff rate during final 15 minutes of the simulation. ${ }^{4}$ Sites in Little Creek had moderate infiltration rates and relatively low hydrologic response. Since the ridges with mudstone parent material in the Little Creek watershed were much less accessible with equipment, simulations were not performed at these locations.

Observations showed that soils, parent material, and vegetation played a significant role in hydrologic response. It was not evident that slope had an influence on hydrologic response. Soil burn severity was closely related to soil/parent material and vegetation with the highest soil burn severity was associated with mudstone parent material and manzanita and knobcone pine vegetation. At sites with higher hydrologic response, it was observed that rainfall was not infiltrating more than 4-6 cm into the soil. The sites with lower hydrologic response, including all Little Creek sites, demonstrated that the majority of rainfall did not infiltrate more than 4-8 cm into the soil, but macropores located in the plots allowed for much deeper infiltration. In most cases macropores were the sole reason for lower hydrologic response at several of the burned sites.

\section{Hillslope Erosion Study}

The hillslope erosion plots installed on the steepest slope class had the highest average erosion rate. The plots located on the lowest slope class had the second highest average erosion rate (Table 5-6). Percent bare soil correlated to erosion rate, with the

\footnotetext{
${ }^{4}$ If the infiltration rate was calculated from manually measured runoff at minute 44 (79 L/min), it would be $0.74 \mathrm{~mm} / \mathrm{hr}(0.29 \mathrm{in} / \mathrm{hr})$.
} 
highest percent bare soil plots having the highest erosion rates. Similarly, plots with the lowest erosion rates had the highest percent vegetation (Table 5-7; Figure 5-10). Rock fragments did not have clear influence on erosion rate, although it was suspected they offered some level of protection for initial moderate intensity storms.

Table 5-6. Annual erosion rates and percent ground cover for Lion's Flat hillslope erosion study plots. *Plots 1-9 were installed Oct 12, 2009 and plots 10-12 were installed December 16, 2009. Ground cover was measured March 11, 2010.

\begin{tabular}{|c|c|c|c|c|c|c|}
\hline & $\%$ slope & $\begin{array}{c}\text { Annual } \\
\text { Erosion } \\
\text { Rate } \\
\text { (metric } \\
\text { tons/ha) }\end{array}$ & $\begin{array}{c}\text { Annual } \\
\text { Erosion Rate } \\
\text { (tons/acre) }\end{array}$ & $\%$ bare & $\begin{array}{c}\% \\
\text { vegetation } \\
\text { (live or } \\
\text { duff) }\end{array}$ & $\begin{array}{c}\text { \%rock } \\
\left(>1 / 2^{\prime \prime}\right)\end{array}$ \\
\hline Plot \#1 & 102 & 15.7 & 7.00 & 85 & 14 & 1 \\
\hline Plot \#2 & 75 & 15.6 & 6.97 & 78 & 13 & 9 \\
\hline Plot \#3 & 78 & 3.03 & 1.35 & 37 & 58 & 5 \\
\hline Plot \#4 & 48 & 5.94 & 2.65 & 26 & 38 & 36 \\
\hline Plot \#5 & 40 & 5.90 & 2.63 & 65 & 10 & 25 \\
\hline Plot \#6 & 72 & 3.65 & 1.63 & 50 & 30 & 20 \\
\hline Plot \#7 & 88 & 6.32 & 2.82 & 60 & 35 & 5 \\
\hline Plot \#8 & 67 & 5.11 & 2.28 & 45 & 17 & 38 \\
\hline Plot \#9 & 70 & 0.78 & 0.35 & 11 & 81 & 8 \\
\hline Plot \#10 & 52 & $1.61^{*}$ & $0.72 *$ & 25 & 74 & 1 \\
\hline Plot \#11 & 66 & $7.91^{*}$ & $3.53^{*}$ & 58 & 39 & 3 \\
\hline Plot \#12 & 39 & $0.56^{*}$ & $0.25^{*}$ & 40 & 59 & 1 \\
\hline
\end{tabular}


Table 5-7. Hillslope erosion plots average erosion rate for slope classes.

Plots 1-9 (Oct. to March) Jan. to March (all plots)

\begin{tabular}{|c|c|c|c|c|}
\hline Slope Class (\%) & $\begin{array}{c}\text { Average } \\
\text { erosion rate } \\
\left(\mathrm{g} / \mathbf{m}^{\mathbf{2}}\right)\end{array}$ & $\begin{array}{c}\text { Average } \\
\text { erosion } \\
\text { rate } \\
\text { (tons/acre) }\end{array}$ & $\begin{array}{c}\text { Average } \\
\text { erosion rate } \\
\left(\mathrm{g} / \mathbf{m}^{\mathbf{2}}\right)\end{array}$ & $\begin{array}{c}\text { Average } \\
\text { erosion rate } \\
\text { (tons/acre) }\end{array}$ \\
\hline $\mathbf{0 - 5 4}$ & 590.9 & 2.64 & 194.9 & 0.87 \\
$\mathbf{5 5 - 7 4}$ & 318.9 & 1.42 & 310.8 & 1.39 \\
$\mathbf{7 5 +}$ & 1016.7 & 4.54 & 515.9 & 2.30 \\
\hline Bare soil (\%) & \multicolumn{5}{|l}{} \\
\hline $\mathbf{0 - 3 9}$ & 284.2 & 1.27 & 101.2 & 0.45 \\
$\mathbf{4 0 - 5 9}$ & 431.1 & 1.92 & 318.8 & 1.42 \\
$\mathbf{6 0 +}$ & 1088.0 & 4.85 & 564.6 & 2.52 \\
\hline
\end{tabular}

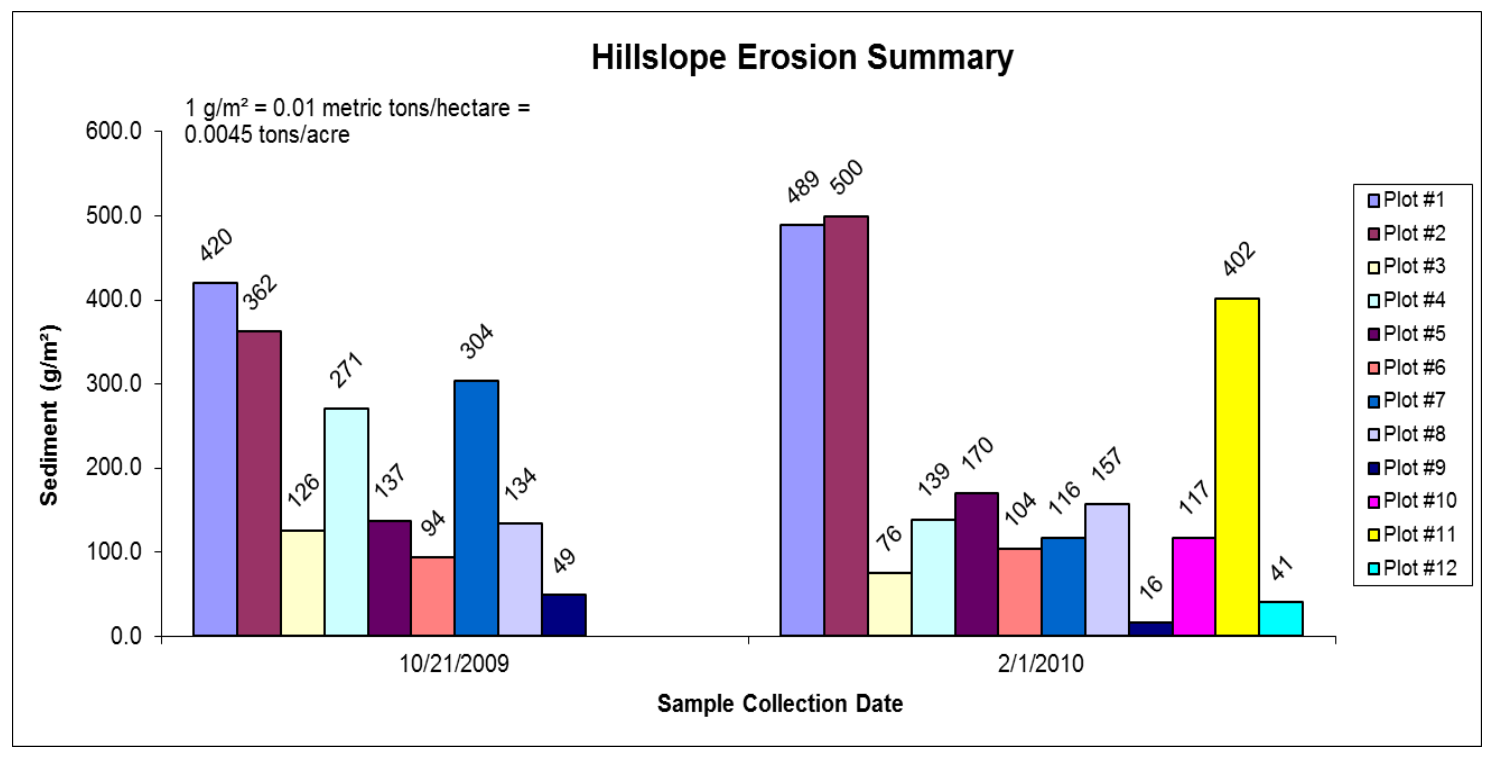

Figure 5-10. Hillslope erosion plot collection totals for October and January storm events.

Data from two hillslope plots located near the UNF rain gage were not analyzed due to errors in data collection. It was observed that these plots had minimal sediment accumulation after storm events. Leaf litter quickly accumulated in plots, and even 
though the slopes were moderate to steep, sediment production from areas with moderate soil burn severity in the redwood/Douglas-fir mixed forest type was minor.

Data from the five sediment fences installed in forested portions of the watershed was not analyzed due to data collection errors. Two of the silt fences were installed downslope of a rill site and although the data quality was very poor, it was observed that sediment continued to be supplied from upslope rill network for multiple storm events with lower rainfall intensities $(3.1 \mathrm{~cm} / \mathrm{hr}$ or 1.2 ”/hr. 15-minute rainfall intensity) after rill initiation from high intensity January 18 storm. Silt fences in swales on moderate slopes (30-40\% slope) in redwood dominated forest observed minimal amounts of sediment accumulation during the first storm season after the fire.

\section{Soil Infiltration Study}

Mini-Disc Infiltrometer tests (MDI) revealed that at the $1 \mathrm{~cm}$ depth, 19 sites (including the control site) displayed strong hydrophobicity, three sites displayed weak hydrophobicity, and one site did not display soil hydrophobicity. Data from the $3 \mathrm{~cm}$ depth showed that 17 sites (including the control site) displayed strong hydrophobicity, five sites displayed weak hydrophobicity, and one site did not display hydrophobic soil properties. WDPT results were not analyzed due to data input error.

When looking at slope position, 78\% of the lower slopes MDI tests indicated strong hydrophobicity at a depth of $1 \mathrm{~cm}$. At a depth of $3 \mathrm{~cm}, 67 \%$ of the lower slope MDI tests indicated strong hydrophobicity. Upper slopes indicated strong hydrophobicity at $82 \%$ of tests at $1 \mathrm{~cm}$ and $3 \mathrm{~cm}$ depths (Figure 5-11). 


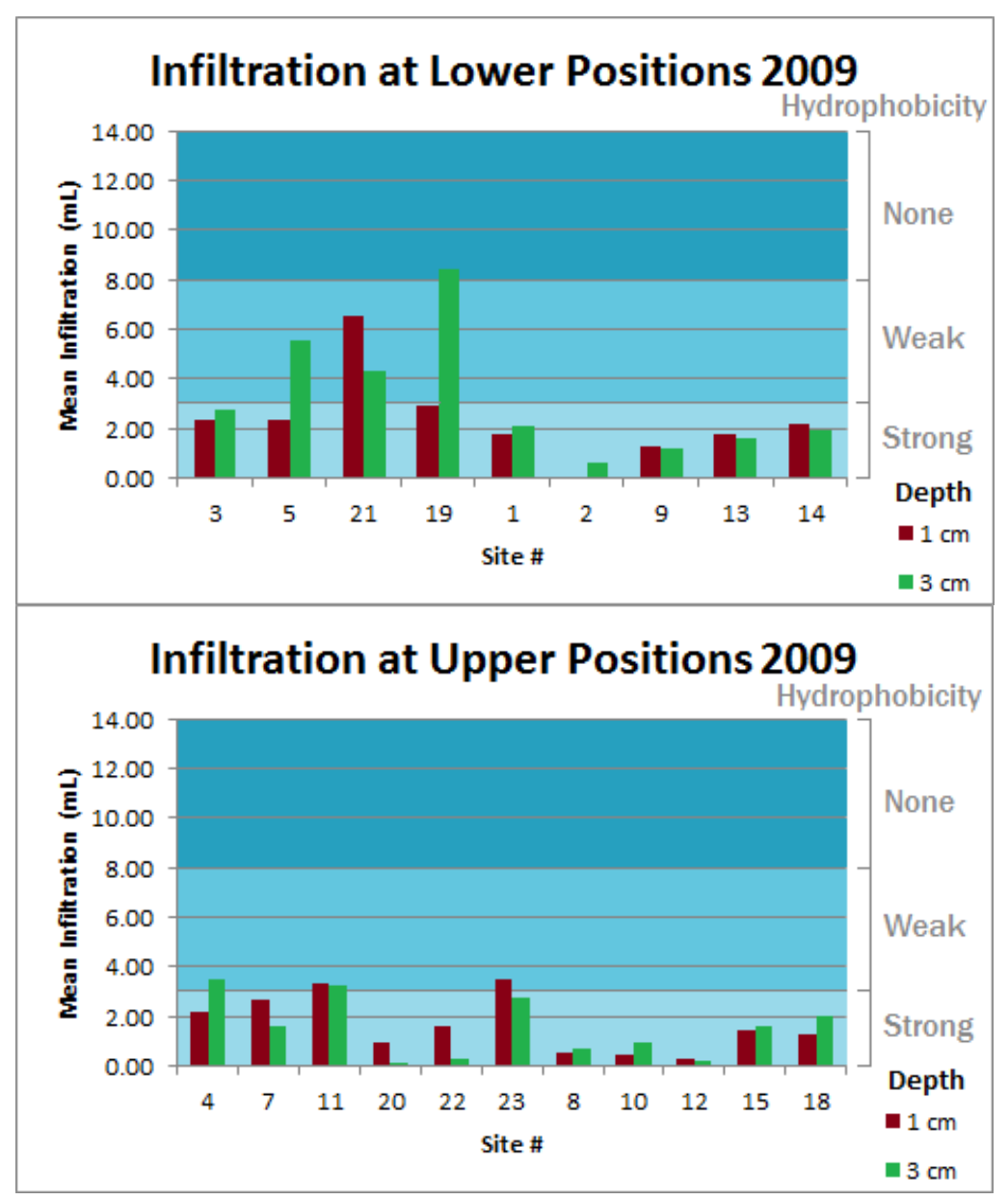

Figure 5-11. MDI summary for upper and lower slope positions (Lau, 2011).

In areas of high soil burn severity, 90\% of MDI tests at a depth of $1 \mathrm{~cm}$ displayed strong hydrophobicity and $70 \%$ of tests at $3 \mathrm{~cm}$ depth displayed strong hydrophobicity. Moderate soil burn severity sites indicated strong hydrophobicity at $70 \%$ of test sites at 1 cm and $3 \mathrm{~cm}$ depths (Figure 5-12). 


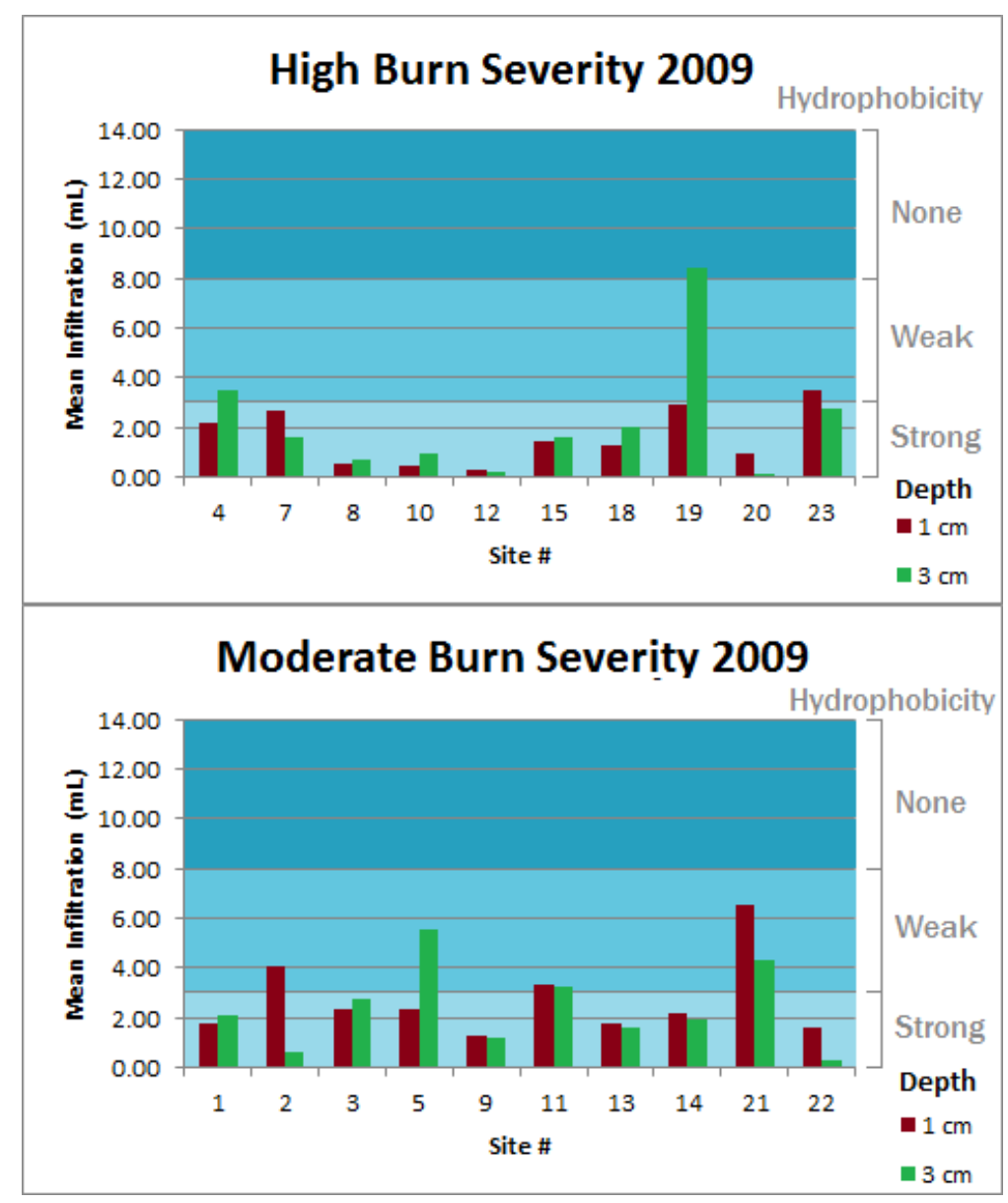

Figure 5-12. MDI summary for high and moderate soil burn severity (Lau, 2011).

Ninety-one percent of the MDI tests indicated strong hydrophobicity at $1 \mathrm{~cm}$ and $3 \mathrm{~cm}$ depths on south-facing slopes. Results were more variable on north-facing slopes, with $67 \%$ of the tests displaying strong hydrophobicity at $1 \mathrm{~cm}$ and $56 \%$ at $3 \mathrm{~cm}$ depth (Figure 5-13) ${ }^{5}$.

${ }^{5}$ Of the 23 sites tested in 2009, only 20 sites were tested in 2010. Sample sites \#16 and \#17 were omitted because of the close proximity and inferred similarity to sample sites \#15 and \#8. Sample site \#6 was omitted because the flagging tape for the transect could not be found. 


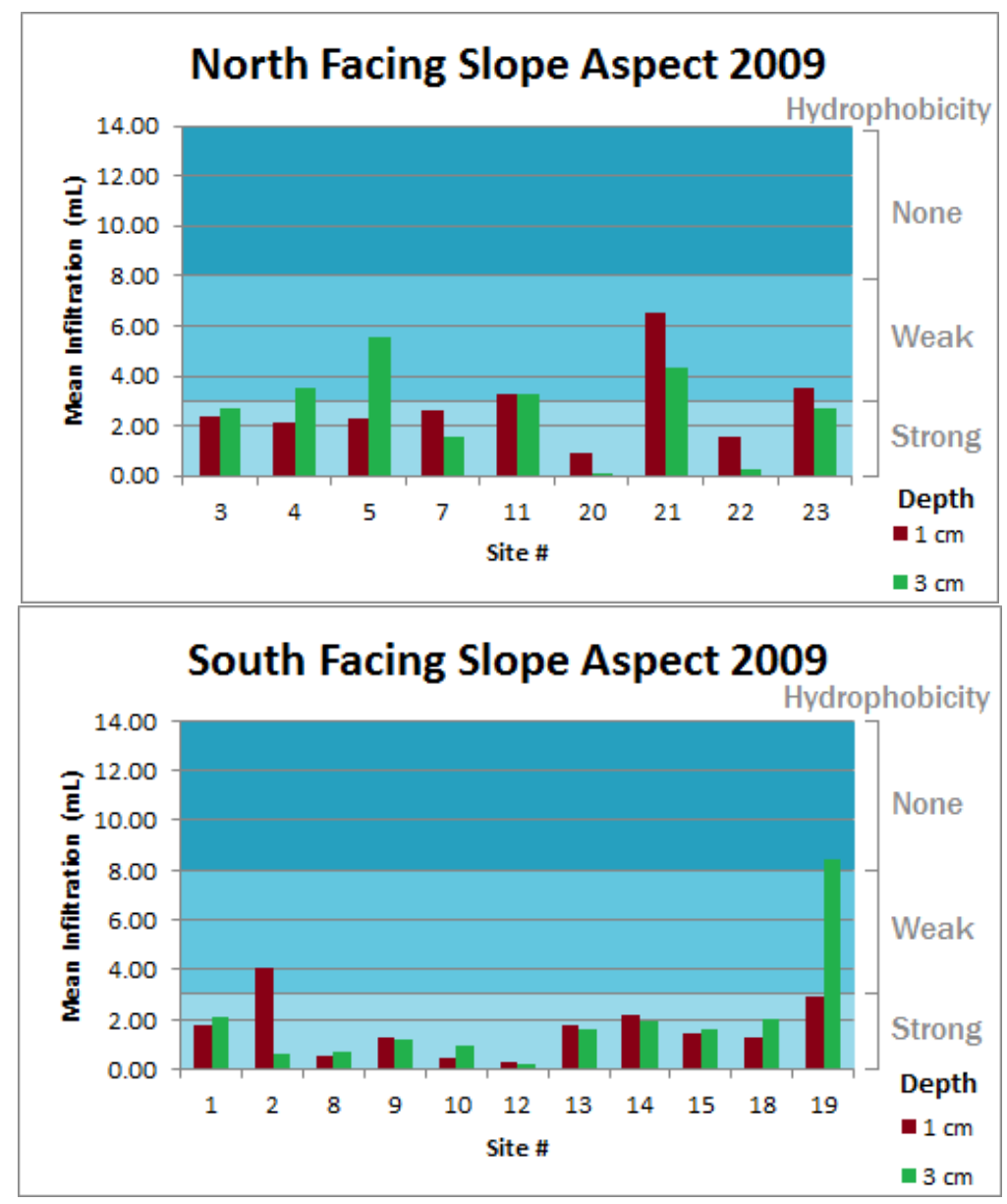

Figure 5-13. MDI summary for North and South facing slope aspect (Lau, 2011). 


\section{CHAPTER 6}

\section{Discussion}

\section{First Year Observations of Watershed Response to Post-Fire Storm Events}

The first over-wintering period after the Lockheed Fire produced 13 storm events with defined hydrographs and complete suspended sediment sample records. Peakflows did not exceed bankfull (1.5 year recurrence interval) during the first year post-fire. Although watershed experienced event precipitation totals (172 $\mathrm{mm})$ and rainfall intensities (10-minute intensity of $87 \mathrm{~mm} / \mathrm{hr}$ ) that were highest of study period, flow response resulted in below average stormflow totals and peakflows (Figure 6-1). Of these 13 storm events, three events demonstrate how a recently burned watershed responds as a function of the characteristics of the precipitation events. The first storm event of the water year occurred on October 13, 2009 and resulted in the highest 24-hour precipitation total for the entire study period (water years 2002-2010). The second event occurred on January 18, 2010 and had the highest 15-minute rainfall intensity of the study, along with significant mass sediment mobilization from hillslope and tributary channel sources. The

third event took place on February 6, 2010 and had lower 15-minute intensity, but higher peakflows resulting in a substantial sediment response. 


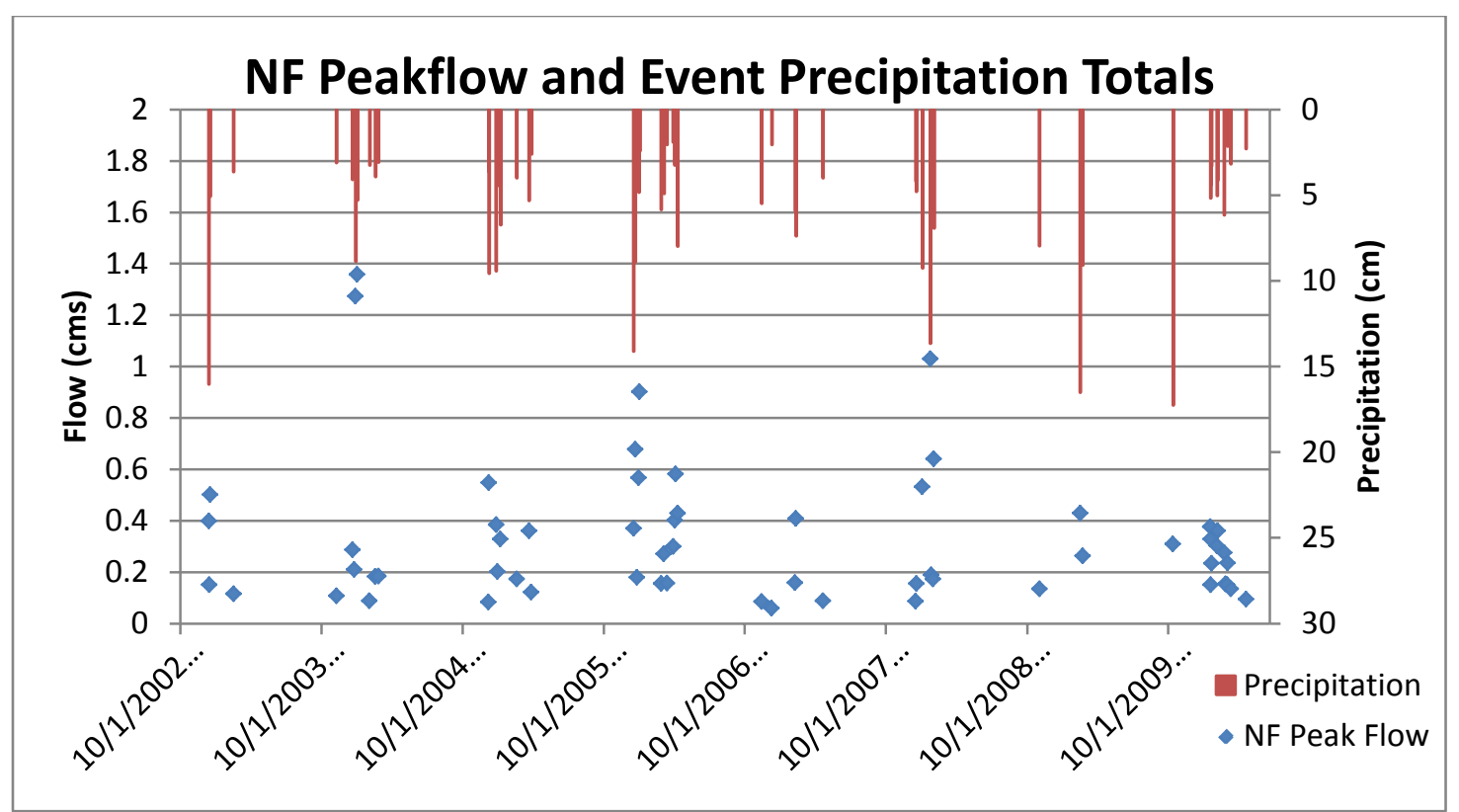

Figure 6-1. North Fork peakflow plot for entire study period (water years 2003-2010).

\section{October 13, 2009 Storm Event}

The first precipitation event after the fire occurred on September $13^{\text {th }}$ with 0.91 inches of rain over a five hour period. The stream flow response was relatively low for this event and there was minimal sediment response. Nearly a month later, the first major defined storm event after the fire occurred October $13^{\text {th }}$, with $17.25 \mathrm{~cm}$ (6.79 in) of rain measured at the UNF rain gage (this figure represents average precipitation over the watershed) over approximately 18 hours. Precipitation amounts ranged from $10.4 \mathrm{~cm}$ (4.1 in) at lower elevations to $20.0 \mathrm{~cm}$ (7.8 in) in the upper watershed. On the ridges of the greater Scotts Creek watershed, precipitation amounts were recorded up to nearly $30.5 \mathrm{~cm}$ (12 in) for a 24 hour period (Lermen et al., 2009).

Monitoring stations differed slightly in response to the storm event, but overall there was a substantial flow and sediment response (Appendix E). UNF recorded the 
winter's highest peakflow ( $0.39 \mathrm{cms}$ or $19.3 \mathrm{cfs})$ and had second highest turbidity and SSC values (693 NTUs, $2401 \mathrm{mg} / \mathrm{L}$ ) recorded for this monitoring station. Flow response at NF was below the peakflow average for the study period and slightly above average turbidity and SSC values (not the highest of the post-fire period). SF was also below the peakflow average, but had the highest peak turbidity and second highest instantaneous peak SSC of the post-fire period.

Areas of mass sediment movement were not observed after this storm event except at the R8 tributary just downstream of the NF and SF confluence. This tributary transported debris large enough to plug a culvert and transport sediment over the road. Total sediment accumulation is estimated to be less than $3.8 \mathrm{~m}^{3}\left(5 \mathrm{yd}^{3}\right)$ and the sediment source is thought to be from a combination of hillslope erosion, dry ravel accumulations, and channel scour from the tributary. This event produced the highest storm precipitation amount of the entire study and had 15-minute rainfall intensities up to $31 \mathrm{~mm} / \mathrm{hr}(1.22$ in/hr). Dry antecedent moisture conditions with well-established ash cover can temporarily prevent soil sealing and decrease post-fire runoff and sediment production, which is likely what happened in this storm event (Larsen et al., 2009). It is also suspected that rainfall intensities were not high enough to trigger overland flow on high soil burn severity areas. High peakflows and peak SSC readings at UNF were potentially related to higher precipitation amounts recorded at higher elevations.

\section{January 18-21, 2010 Storm Events}

The second major precipitation event of the year was a series of storm fronts that hit the Central Coast from January 18-21, 2010. This event was separated into three 
discrete storm events, since each had well defined hydrographs and there was 6-hour or longer rain-free periods between precipitation events. The first of these storm events produced extremely high rainfall intensity and there were many areas of mass sediment production from surface erosion leading to concentrated debris and mud flows, and channel-derived debris flows. A 10 -minute rainfall intensity $(87 \mathrm{~mm} / \mathrm{hr}$ or $3.44 \mathrm{in} / \mathrm{hr})$ triggered overland flow and sediment production from the upper slopes of the watershed resulting in the highest peak turbidity and SSC values at NF and UNF for the study period (2002-2010). The SF response to this storm was substantial, but turbidity and SSC values did not reach the highest levels for the study period, as occurred at the other monitoring stations.

The highest instantaneous SSC value recorded at the NF monitoring station was $5012 \mathrm{mg} / \mathrm{L}$, with an associated turbidity value of $2032 \mathrm{NTU}$, both at a relatively moderate flow of $0.27 \mathrm{cms}$ (9.54 cfs). SSC values went from $199 \mathrm{mg} / \mathrm{L}$ at 10:00 a.m. to $5012 \mathrm{mg} / \mathrm{L}$ at 11:00 a.m. and back down to $1245 \mathrm{mg} / \mathrm{L}$ at 12:00, where it continued to rapidly fall (Table 6-1). Stream flow spiked at 11:30 a.m. at $0.38 \mathrm{csm}$ (13.3 cfs), which occurred between hourly sediment samples. Since SSC is often related to flow, it is possible that SSC spiked with flow and was higher than the recorded value. On the other hand, SSC may have peaked on the rising limb of hydrograph, displaying clockwise hysteresis with flow (Figure 6-2). Clockwise hysteresis is common and is often associated with a flush of available sediment from early season storms (Williams, 1989). The San Lorenzo River watershed neighboring Scotts Creek to the east was not affected by the Lockheed fire and displayed reverse hysteresis for the same storm event, which is likely due to slower release of sediment from large erosion features such as landslides and eroded 
banks (Conaway et al., 2012; Williams, 1989; Bogen, 1980). The SF monitoring station also observed an early spike in SSC, but UNF SSC was closely associated with flow and does not appear to display a hysteresis effect.

Table 6-1. Peakflow and associated maximum SSC for the NF, UNF, and SF monitoring stations during the January 18, 2010 storm event.

\begin{tabular}{|l|l|c|c|c|}
\hline & Date \& Time & SSC (mg/L) & Flow (cms) & Flow (cfs) \\
\hline NF & $1 / 18 / 201010: 00$ & 199 & 0.11 & 3.78 \\
& $1 / 18 / 201011: 00$ & 5012 & 0.27 & 9.54 \\
& $1 / 18 / 201012: 00$ & 1244 & 0.33 & 11.54 \\
\hline & $1 / 18 / 201013: 00$ & 497 & 0.21 & 7.42 \\
\hline UNF & $1 / 18 / 201010: 00$ & 110 & 0.11 & 3.93 \\
& $1 / 18 / 201011: 00$ & 2940 & 0.31 & 11.09 \\
& $1 / 18 / 201012: 00$ & 659 & 0.28 & 9.98 \\
& $1 / 18 / 201013: 00$ & 259 & 0.22 & 7.62 \\
\hline SF & $1 / 18 / 201010: 00$ & 95 & 0.03 & 1.18 \\
& $1 / 18 / 201011: 00$ & 1037 & 0.07 & 2.55 \\
& $1 / 18 / 201012: 00$ & 641 & 0.16 & 5.57 \\
& $1 / 18 / 201013: 00$ & 256 & 0.13 & 4.63 \\
\hline
\end{tabular}

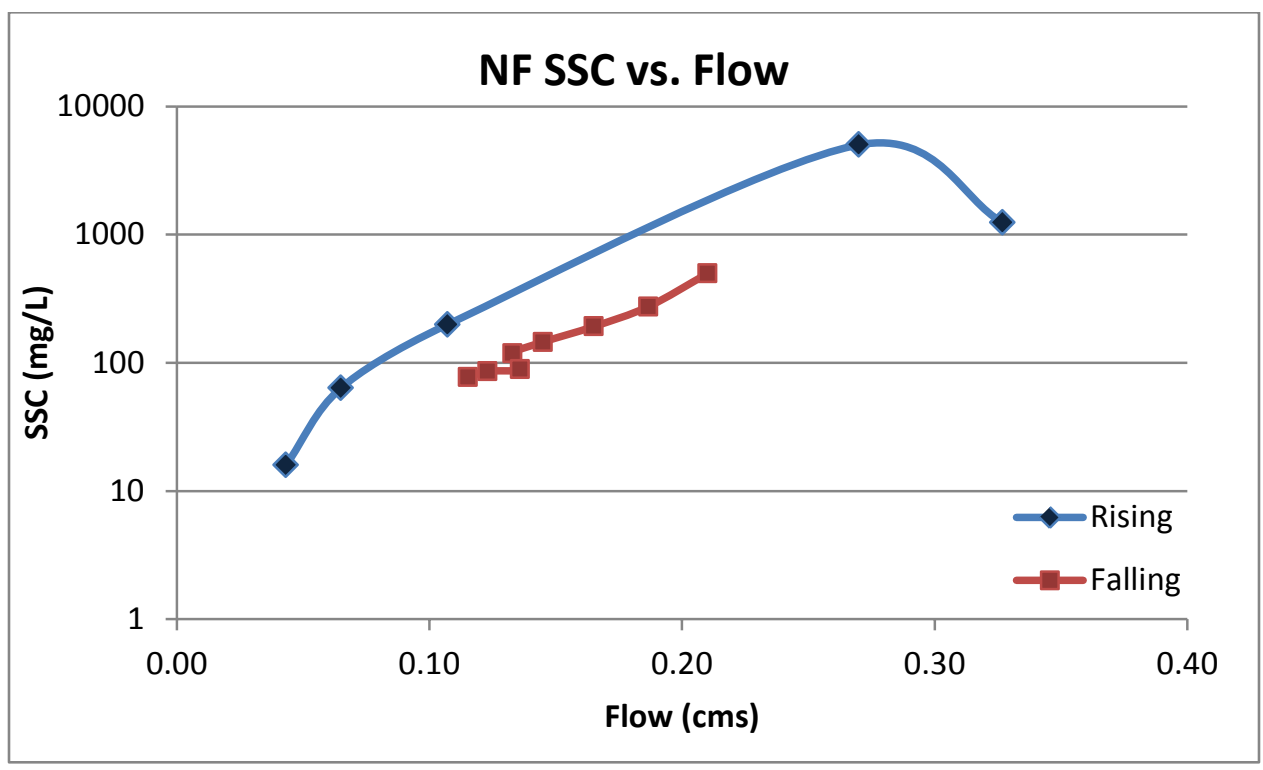

Figure 6-2. North Fork SSC versus flow displaying clockwise hysteresis.

The pronounced sediment response during the January $18^{\text {th }}$ storm event can be attributed to high intensity rainfall initiating surface erosion and small debris flows in 
multiple areas. The watershed was thoroughly explored to identify areas of mass sediment movement and the majority of these sites originated from the upper watershed on the south facing slopes. The predominate vegetation type in these areas were chaparral and knobcone pine that were almost entirely consumed by the fire. Debris flows deposits were found on roads or other low gradient depressions and originated from small tributaries. One tributary (R8) had debris torrent evidence with larger rock fragments and woody debris (Figure 6-3). Two areas were identified as having an intricate rill network that delivered fine sediment to active stream channel. Of all the sediment deposition sites identified in the Little Creek watershed, only the R8 debris flow and the two areas of rilling were hydrologically connected and likely had a significant sediment contribution to Little Creek (Figure 6-4). There were no depositional areas found in UNF and only two small sediment depositions found in SF, both of which deposited the majority of the sediment on the road prism. Since identified sediment sources occurred on the upper slopes of the watershed, it is likely that vast amounts of sediment originated in the headwaters and was transported downstream by small tributaries. 


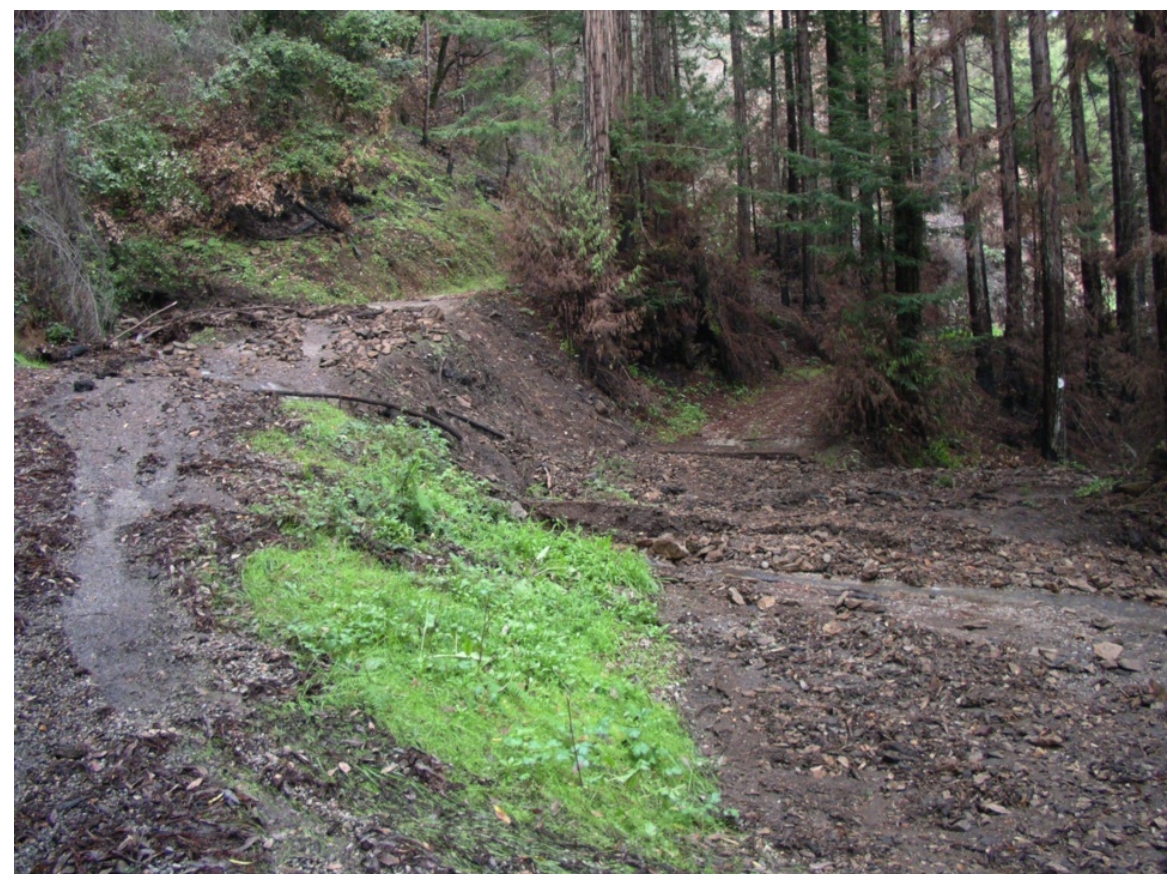

Figure 6-3. Debris flow deposits on Little Creek Road from the R8 tributary. 


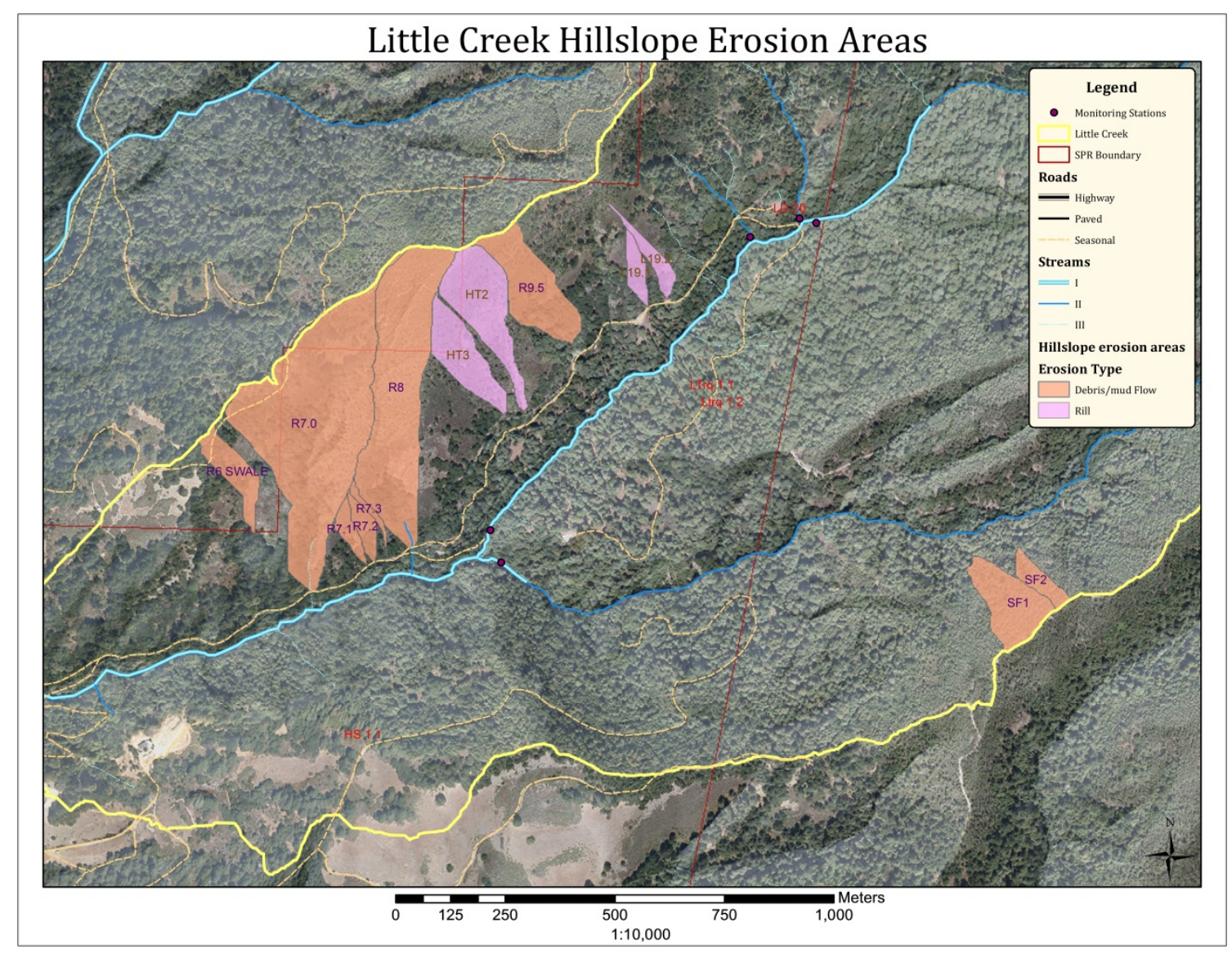

Figure 6-4. Map of hillslope-derived sediment sources in Little Creek Watershed. Subwatersheds were created from depositional points using $1 \mathrm{~m} \mathrm{LiDAR}$ derived DEM on ArcGIS.

One hillside with an extensive rilling network was broken up into three $10 \mathrm{~m}^{2}$ plots and rill depth and width were measured with $1 \mathrm{~m}$ transects using a ruler and cloth tape (Figure 6-5). The X/Y database was imported into ArcGIS to get cross-sectional areas and then calculated eroded area. Although the precision of this method is recognized to be low, the amount of sediment eroded from the hillslope was substantial and supported by the estimate of $3.68 \times 10^{5} \mathrm{~kg} / \mathrm{ha}$ (164 tons/acre). In addition to the extremely high short duration rainfall intensity experienced during this storm, additional 
factors contributing to rilling on these hillslopes were high clay content, greater slope length, and lower infiltration rates (Niebrugge, 2012) (Figure 6-6).

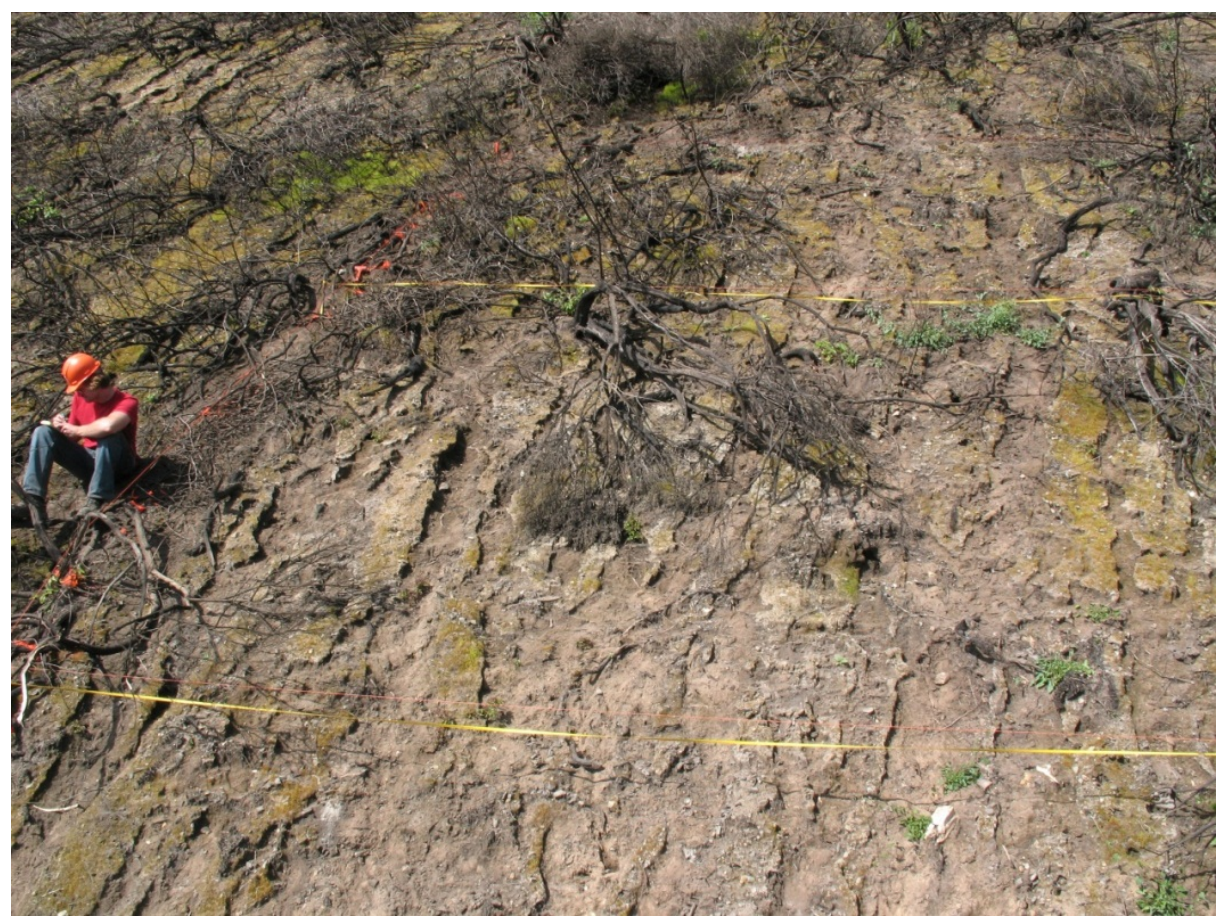

Figure 6-5. Rill erosion plot on south-facing slope between the NF and UNF monitoring stations. 


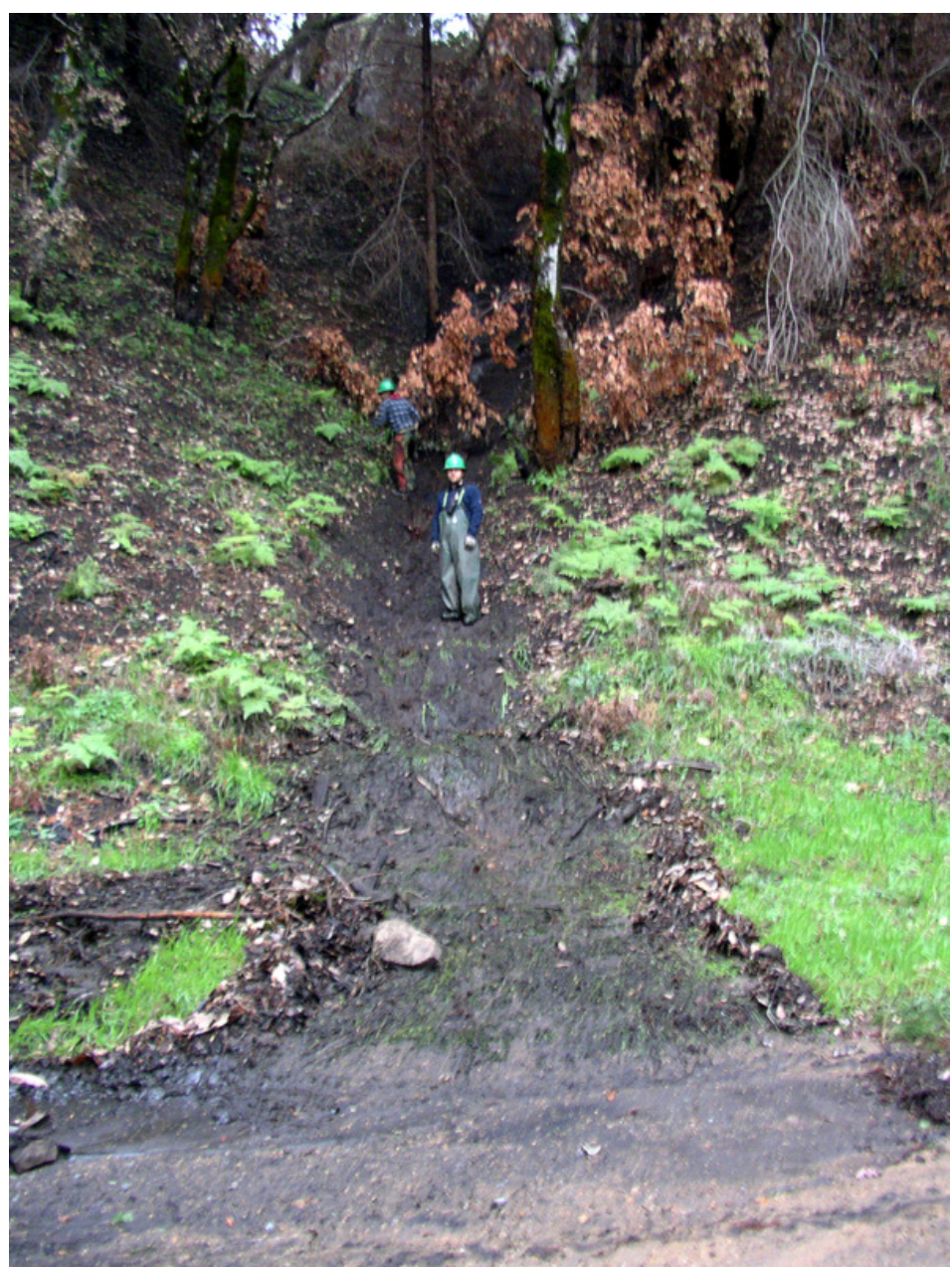

Figure 6-6. Channel scour in a swale downslope from extensive rilling caused by a debris flow after the January 18, 2010 storm event.

\section{February 6, 2010 Storm Event}

The February $6^{\text {th }}$ storm event also initiated a substantial stormflow and sediment response due to high intensity rainfall (15-minute rainfall intensity of $30 \mathrm{~mm} / \mathrm{hr}$ or 1.17 in/hr). The antecedent soil moisture condition for this event was moderately wet, with approximately $330 \mathrm{~mm}$ (13 in) of precipitation occurring in the previous 28 days. The NF and SF monitoring stations had the highest peakflows for the first year post-fire and UNF had second to highest peakflow. It is likely that sediment was remobilized and 
transported further down the watershed in this storm event. It was observed that the rill sites continued to produce sediment during this storm event, but no new areas of mass wasting were observed. Rilling likely continued due to preferential surface pathways in the rill network created in the January storm event. Surface flow concentrations continued to erode and transport fine sediment in the colluvium soil type.

Subsequent storm events continued to have large streamflow and sediment response, but lower than the previously described storm events. Debris flows were only observed after the October $13^{\text {th }}$ and January $18^{\text {th }}$ storms, while rilling appeared to continue with multiple storm events after the January $18^{\text {th }}$ storm. The two sediment deposits found in the upper South Fork were not identified until near the end of the storm season; therefore it is unknown which storm event created these small debris torrents. There was also little evidence that these debris torrents contributed sediment to the South Fork, since the road prism appeared to capture the majority of sediment.

\section{Relationship Between Wildfire and Sediment, Flow, and Precipitation}

The 1997-98 storm season was a record year with flows reaching flood stage. The combination of high flows and saturated soil conditions caused numerous areas of bank erosion and shallow near-stream landslides. Storms of this magnitude produce watershed conditions that require many years for recovery. Since these storm events caused a major increase of sediment delivery to the stream which led to major geomorphologic change, this study used water quality data beginning in the 2002-03 winter in order to minimize the influence of 1997-98 storm season. 


\section{Suspended Sediment Concentration}

Statistical analyses differed in determining the influence of fire on the relationship between SSC and flow for each monitoring station except at the NF station. Both analyses resulted in fire having a significant, but negative influence on the SSC and flow relationship at NF, meaning that SSC was lower after the fire in comparison to values at similar flows prior to the fire. The results between the two analyses differed for SF and UNF. The preliminary statistical analysis unsuccessfully addresses the issue of severe positive autocorrelation, so it is preferable to refer to the second analysis results. Autocorrelation is common in time series data and fails to meet the assumption of uncorrelated or independent error terms (Neter et al., 1996).

With the second statistical analysis, SF was not statistically significant and both NF and UNF were statistically significant with fire having a negative effect on SSC, especially at lower flows, low SSC, and low API. The negative effect on SSC with flow may be part of a long-term trend at NF seen throughout the study. UNF results were similar to 2005 results in the calibration period and are possibly associated with normal annual variability.

Sediment production after the fire was highly correlated with high intensity rainfall. When rainfall intensity reached rates high enough to trigger sediment production, it usually was short lived and resulted in relatively quick flushes of sediment in the stream system, as seen in the January $18^{\text {th }}$ storm event. There was also no major flow events (event peakflows did not reach bankfull stage) the first storm season after the fire. There are many factors that may be contributing to fire having a negative effect on 
SSC including the fact that there was not any large flow events, lack of near-stream sediment sources and increase in hillslope-derived sediment sources possibly allow transported sediment to deposit out prior to entering stream, and sharp spikes in sediment response were influential to event SSC.

\section{Event Sediment Load}

Preliminary analysis resulted in a statistically significant lower suspended sediment load for NF and SF versus EI30 and 28-day previous rainfall. Less than 50\% of the variability of SSC was explained in these models, leaving more than half of the variation due to unexplained factors. UNF was determined to not be statistically significantly related to these factors, with a p-value greater than 0.05 . Secondary analysis used different models to explain fire influence on event suspended sediment load, but models were not statistically significant. The NF model was slightly significant, with fire having a negative effect; however, when the outlier was removed, the model was no longer significant.

Sediment response appeared largely related to high intensity rainfall for short durations in post-fire events, and the event loads did not reflect large increases associated with the fire. Pre-fire storm events were twice as long in duration on average and had higher average peakflows resulting in larger event loads. Average peak turbidity and SSC were higher in the pre-fire period compared to post-fire at SF and UNF. NF peak turbidity and SSC post-fire had higher averages than pre-fire and this may be attributed largely to the direct sediment contribution from the rill sites on the upper south facing slopes of the watershed between the NF and UNF monitoring stations. 


\section{Stormflow Volume}

Peakflows are typically higher following a wildfire in a forested watershed (Moody and Martin, 2001; Helvey, 1980). This is often due to fire-induced hydrophobic layers in soil that decrease infiltration and increase runoff and sediment yield (Ice, 2003; Robichaud et al., 2008; Pierson et al., 2003; Doerr et al., 2010). While fire can increase peakflows, it is not directly related to an increase in stormflow volume or annual water yield (Campbell and Morris, 1988). Preliminary statistical analysis resulted in a significant but negative response of fire on stormflow volume in relation with event basin precipitation volume and 28-day previous rainfall at NF and UNF. In other words, event stormflow volumes were lower in relation to basin precipitation volume and 28-day previous rainfall after the fire. Fire was not a statistically-significant predictor for SF stormflow volume. Statistically-significant unexplained variability in stormflow volume remained with this model. Secondary analysis using different models did not find a statistically-significant influence from fire on stormflow volume for all monitoring stations.

It is noteworthy that a forested watershed that was almost entirely consumed by fire did not have evidence of elevated stormflow volume the first year post-fire. Lower burn severity occurred in the redwood forest type, which resulted in less soil water repellency in the well-drained soils, and the presence of macropores were identified as a factor that allowed for increased infiltration. These factors help explain the finding that stormflow volume did not increase the first winter after fire in a coastal redwood forest. 


\section{Near-Stream Sediment Source Survey}

The first survey conducted in 2002 accounted for all near-stream sediment sources dating back to the 1997-98 storm season. Due to the fact that 1997-98 had annual rainfall totals well above average and flows above flood stage, Little Creek experienced many areas of large landslides and eroded banks. These features resulted in a large number of sediment sources, many with substantial volumes (Figure 6-7). The subsequent sediment surveys found decreasing numbers of contributing features with smaller volumes. Many of the previously recorded features were noted as still contributing, but it was difficult to obtain high levels of accuracy when quantifying the change in volume of these features. It would have been beneficial to have erosion pins or other methods to record and quantify continuously eroding features.

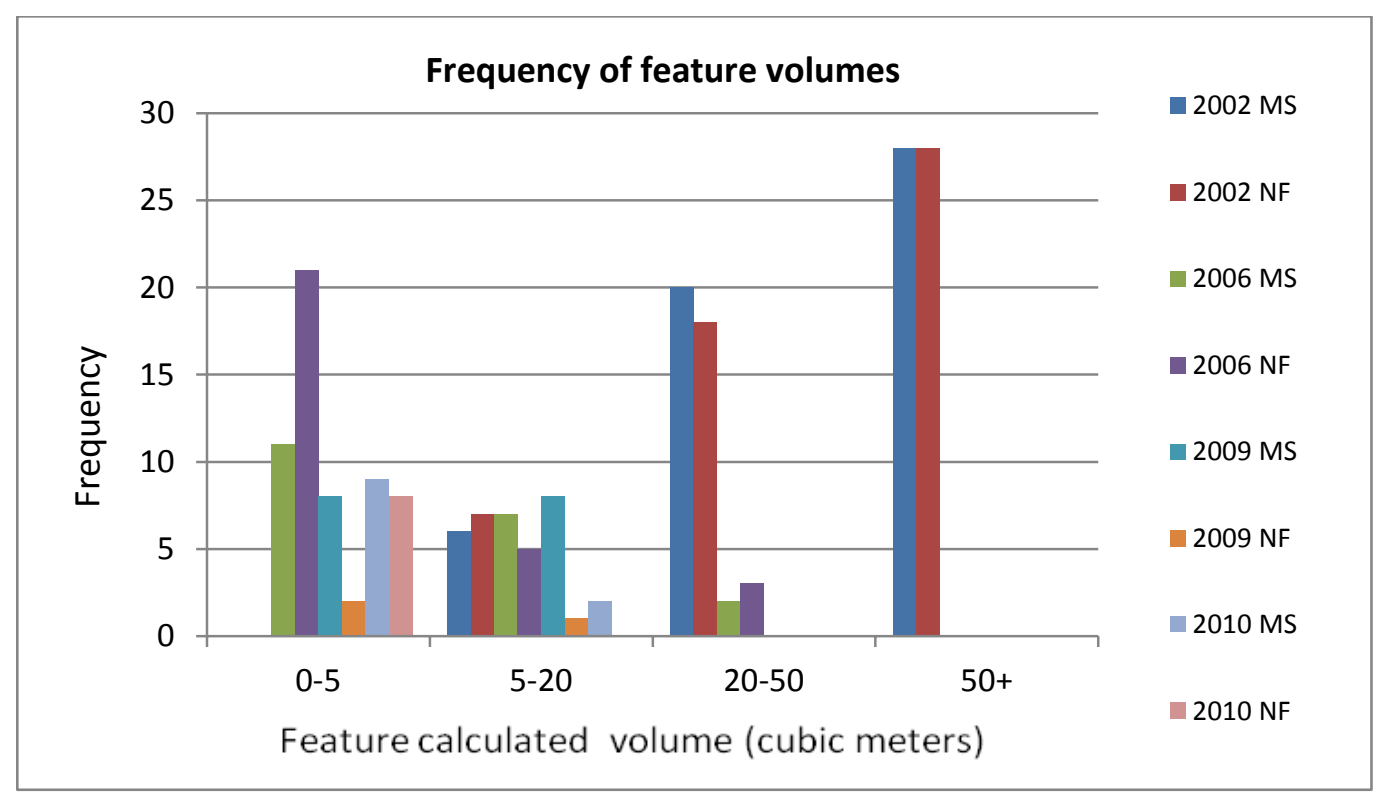

Figure 6-7. Plot of frequency of feature volumes for each reach and year. 
The number of near-stream sediment sources continued the decreasing trend after the fire. The amount and volume of sediment sources decreased at MS compared to 2009 survey, although NF had more features and slightly higher volume than recorded in the 2009 survey. Eroded banks were the most common feature recorded. Fire-induced dry ravel accumulations, especially in inner gorge sections of the stream channel, and tree fall from fire contributed sediment to stream channel at relatively low volumes. It is important to recognize that even though the majority of the watershed experienced a wildfire that resulted in reduced vegetation and ground cover, the amount and volume of near-stream sediment sources remained relatively low. These results help explain the findings that SSC and sediment load did not increase after the fire, since near-stream sediment sources did not significantly contribute to sediment in the channel.

\section{$\underline{\text { Rainfall Simulator }}$}

Rainfall simulations were conducted to determine if the hydrological processes changed after the wildfire. These simulations help to explain precipitation and runoff relationships, which are directly related to erosion. Unfortunately, much of the area in Little Creek where high soil burn severity, shallow soils, mudstone parent material, and surface erosion occurred was inaccessible with the equipment needed to run simulations. This factor led the research crew to identify sites in the greater Scotts Creek watershed that has similar site characteristics.

Rainfall simulations in Little Creek were conducted in forested areas with different soil types and soil burn severities. Simulations on burned sites had relatively low hydrologic response and it was observed that macropores in the soil were an avenue for water to infiltrate deeper in the soil. It is probable that since these sites were in 
forested areas there was a greater amount of macropores from burnt or decayed roots and insect activity. Doerr et al. (2010) identifies the spatial variability of water repellent soils and the influence of macropores reducing surface runoff. More ground cover from leaf litter, which dissipates the impact of rainfall, was also observed in forested areas.

The Boyer Creek rainfall simulation occurred on a ridge in chaparral/knobcone pine vegetation with high soil burn severity. The infiltration rate at this site was very low (0.11 L/min). Dry soil was present at 2.5 to $5.1 \mathrm{~cm}(1-2 \mathrm{in})$ depth in the plot after the rainfall simulation was complete, indicating strong soil water repellency. Other factors that possibly could be contributing to low infiltration rates is soil sealing creating strong soil repellency or the high percentage of the soil surface being covered with rock fragments.

The Penstock rainfall simulation site, located on the Upper Scotts Creek and Mill Creek ridgeline where one side of the ridge burned and other side unburned, also displayed extremely low infiltration rates. Soils at this site were very shallow and dominated with mudstone rock fragments. Hydrologic response was high at the unburned site as well, which infers that natural soil hydrophobicity occurs at this site. In this case, the presence of vegetation in the unburned site will play a greater role in rain drop interception, minimize rain splash erosion, and will likely have less significant sediment response after a storm event. The observation of soil pedestals on the burned site, but not in control site, supports this contention. 


\section{Hillslope Erosion Study}

The hillslope erosion study plots were established to document erosional processes associated with slope in a redwood forest that experienced high soil burn severity. As anticipated, the plots with the steepest slope recorded the highest amount of sediment per plot, with the average annual erosion rate of $10,087 \mathrm{~kg} / \mathrm{ha}(4.5 \mathrm{t} / \mathrm{ac})$ in plots with slopes greater than 75\% (Table 5-7). Ground cover was recorded at end of the storm season, making it difficult to determine how ground cover changed through the winter and how it influenced surface erosion. There was correlation between percent bare soil and amount of erosion, inferring that vegetation (live or duff) and rock fragments reduced the amount of erosion in the plots. Plots with $60 \%$ or greater bare soil had an average annual erosion rate of 10,984 kg/ha (4.9 t/ac). Soil pedestaling was observed in some plots where rock fragment protected soil from erosion. Pedestaling was similarly observed throughout the watershed, included forested areas, after the first storm season post-fire (Figure 6-8).

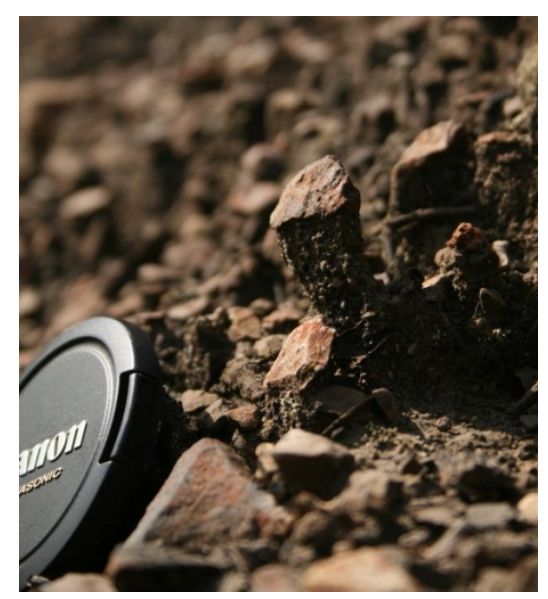

Figure 6-8. Soil pedestals observed after a storm event in the Little Creek watershed (photo provided by D. Perkins). 
The annual erosion rates were high when extrapolated to $\mathrm{kg} / \mathrm{ha}$ (as high as 15,692 $\mathrm{kg} / \mathrm{ha}$ or $7 \mathrm{t} / \mathrm{ac}$ in plot \#1 with $102 \%$ slope and $85 \%$ bare soil). Knowing that there was a significant amount of sediment mobilized, some important questions are left unanswered: What percentage of sediment that was recorded would likely be delivered to the steam channel? What percentage is trapped in depositional areas (roads, trails, etc.)? How long does it take for sediment to reach a channelized waterway? These questions are difficult to answer, but should be considered in future similar studies. It will also be interesting to see what the following year's data results reveal with increasing vegetative growth over time.

\section{$\underline{\text { Soil Infiltration }}$}

Soil infiltration tests indicated that the majority of the soils tested in Little Creek watershed had some degree of hydrophobicity. Strong water repellency was displayed at $82 \%$ of sites at $1 \mathrm{~cm}$ depth and $73 \%$ of the sites at $3 \mathrm{~cm}$ depth. In high soil burn severity areas $90 \%$ of sites at $1 \mathrm{~cm}$ depth displayed strong water repellency compared to $70 \%$ at 3 cm depth.

The single control (unburned) site that was tested displayed strong hydrophobicity at 1 and $3 \mathrm{~cm}$ depths, suggesting that some degree of natural hydrophobicity may be present in the soil. Since there was only one control site test for hydrophobicity, the degree of natural hydrophobicity that exists without recent fire is unknown. Infiltrometer tests also lead to the conclusion that fire induced soil hydrophobicity occurred in the watershed and likely played a role in increased runoff and sediment production. 


\section{Limitations of Data and Recommendations}

Suspended sediment sampling requires a significant amount of effort in order to collect continuous samples throughout a storm event. Malfunctions in sampling and monitoring equipment were common, with issues including battery failure, programming errors, clogged stilling well intakes, etc. Errors would occasionally occur due to the sampler intake boom position being too low, resulting in sampling of bedload, and the intake getting transported out of the water column by debris. These problems were addressed through frequent visits to monitoring stations, except during storm events accompanied by high winds, when conditions were unsafe for field crews.

Samplers were programmed to take samples hourly, which can lead to missing peak SSC. One option is to conduct turbidity threshold sampling (TTS) which will allow for samples to be taken based on turbidity rather than at a fixed time (Lewis and Eads 2009). Turbidity probes were installed at monitoring stations, but probes did not provide accurate data due to many uncontrollable factors.

The occurrence of UNF flows being higher than NF creates some question regarding the accuracy of flow data and the rating curves established for these stations. One issue that was observed at UNF was that without a flume, the tail of pool was the control and debris and coarse sand often altered the height of the pool tail-out. This caused inconsistency in stage height and therefore caused flow to fluctuate. The rating curve is also not well defined at higher flows and may be over-predicting flow. Continued streamflow and suspended sediment monitoring is recommended to evaluate 
the continuing effects of fire. It is also recommended that a flume be installed at UNF and that flumes at other monitoring stations be repaired to minimize leakage.

The mini-disc infiltrometer is a relatively new method for measuring infiltration. Water drop penetration time tests were compared with MDI tests to observe variability of results, but WDPT data was lost during transfer of data. While performing MDI tests, it was observed that when ash was present on the soil surface, even in small amounts, it influenced the test with its water adsorbing properties. This occurred more often on the 1 cm depth tests and an attempt was made to redo tests when this occurred. It is possible that some of the tests still had the presence of ash influencing the results, showing less hydrophobicity than what occurred. It is recommended to conduct periodic soil infiltration tests to determine how long hydrophobic layers persist. Also, additional tests conducted in unburned control sites with different soil types and vegetation would be beneficial in determining the spatial variability of natural hydrophobicity. All new hydrophobicity tests should have corresponding WDPT tests to compare accuracy and variability of results.

The main challenge with rainfall simulations was to avoid disturbing the site while setting up the equipment. It was also difficult to find sites with the right combination of characteristics and open space to set up the equipment. Continued rainfall simulations will provide a range to data for further analysis. It would be desirable to also collect sediment samples as well as runoff volume from rainfall simulations to determine the amount of sediment production associated with different rainfall rates. 
Continuous monitoring of sediment production, SSC, flow parameters, and event sediment load for the second and third year post-fire will be allow researchers to determine how the watershed recovers after fire. Elements of this monitoring will be difficult to evaluate, as salvage logging occurred using ground based, cable and helicopter harvesting methods.

The hillslope erosion plots located in Lions Flat did not represent the entire watershed. Without a valid sampling regime it made it difficult to make inferences from the results. It is recommended that hillslope erosion plots be installed in various sites throughout the watershed representing different site characteristics to get a better understanding of hillslope erosion. 


\section{CHAPTER 7}

\section{Conclusion}

The watershed response the first year after the Lockheed Fire revealed minimal effects on suspended sediment transport. Regression analyses determined slight effect of fire on SSC, event sediment loads, and stormflow volumes compared to eight years of pre-fire data. SSC values decreased in relation to flow after the fire at NF and UNF monitoring stations and were insignificant at SF. The fire effect on stormflow and sediment load at all stations was not statistically significant in the first year after fire.

Post-fire peakflows did not reach bankfull levels (expected to occur every 1.5-2 years) and event stormflow volumes were relatively small compared to pre-fire events. Fire-induced soil water repellency was apparent throughout the watershed, although rainfall simulations observed macropores to be avenues of accelerated infiltration, especially in forested areas.

Few near-stream sediment sources were identified the first year after the Lockheed Fire. Total annual volume $\left(50 \mathrm{~m}^{3}\right)$ of sediment from mainly eroded streambanks in the MS and NF reaches were lower than previous near-stream sediment source survey volumes. Although new sources of sediment from upslope features (dry ravel, tree fall) were influenced by the fire, the volume from these features was minor.

While the amount and volume of near-stream sediment sources were minimal, new hillslope sediment sources were numerous, particularly in the January 18, 2010 storm event. High-intensity rainfall rates, as high as $87 \mathrm{~mm} / \mathrm{hr}$ (3.44 in/hr) for a 10- 
minute interval, triggered mass sediment production in the form of debris torrents and debris flows. The majority of sediment mobilized by this high intensity rainfall event on January 18, 2010 was observed to be captured by roads, landings, and natural depressions in the landscape. Out of the twelve locations where hillslope-derived erosion was observed, three sites were identified having direct sediment contribution to stream channel. Two of these sites consisted of debris torrents in steep tributaries (slopes greater than 55\%) on the south facing slope where evidence of channel scour was observed. The third site was a debris flow originating from the extensive rill network, also on the south facing slope, that produced fine sediment that was transported during ephemeral flows. SSC values went from $199 \mathrm{mg} / \mathrm{L}$, peaking to 5,012 mg/L (highest value of study period), and back down to $497 \mathrm{mg} / \mathrm{L}$ in a 4-hour period at the NF monitoring station after this storm event.

Various methods of research concluded that hillslope sediment production was influenced by strong soil hydrophobicity, steep slopes, reduced ground cover, and high soil burn severity. MDI tests taken throughout the watershed determined $90 \%$ of sites exhibiting high soil burn severity displayed strong water repellency at $1 \mathrm{~cm}$ depth. Rainfall simulations indicated the lowest infiltration rates (as low as $0.11 \mathrm{~L} / \mathrm{min}$.) in the chaparral/knobcone pine vegetation type and considerably higher infiltration in forested areas (as high as $0.71 \mathrm{~L} / \mathrm{min}$ ). Data collected from hillslope erosion plots revealed that steep slopes ( $75 \%$ or greater) and ground cover (60\% or greater bare soil) had the highest erosion rates $\left(1.1 \times 10^{4} \mathrm{~kg} / \mathrm{ha}\right.$ or 4.9 t/ac annually).

The Little Creek watershed response to wildfire was greatest on the ridges and south facing slopes comprised of chaparral and knobcone pine, while fire effects on the 
forested portion of the watershed were much lower. This study only addressed the watershed response for the first year post-fire and the effects of fire will likely continue for several years. Subsequent research in the watershed will address the continued recovery from fire under varying winter storm inputs. 


\section{Bibliography}

Asselman, N. E. M. (1999). Suspended sediment dynamics in a large drainage basin: the River Rhine. Hydrologic Processes, 13: 1437-1450.

ASTM International, (2003). D1889-00 Standard test method for turbidity of water. In: ASTM International, Annual Book of ASTM Standards, Water and Environmental Technology, 2003, v. 11.01, West Conshohocken, Pennsylvania, 6 Pp.

Benavides-Solorio, J. D. D., \& MacDonald, L. H. (2005). Measurement and prediction of post-fire erosion at the hillslope scale, Colorado Front Range. International Journal of Wildland Fire, 14(4), 457.

Benavides-solorio, J. D. E. D. (2003). Post-fire Runoff and Erosion at the Plot and Hillslope Scale, Colorado Front Range. Dissertation. Colorado State University.

Benda, L. (2003). Effects of post-wildfire erosion on channel environments, Boise River, Idaho. Forest Ecology and Management, 178(1-2), 105-119.

Berndt, H. W. (1971). Early Effects of Forest Fire on Streamflow Characteristics. Notes. Retrieved from http://treesearch.fs.fed.us/pubs/26375

Bogen, J. (1980). The hysteresis effect of sediment transport systems. Norwegian Journal of Geography, Vol. 34, Issue 1

Brabb, E.E. (1997). Geologic Map of Santa Cruz County, California: a digital database: U.S. Geological Survey, Open-File Report OF-97-489, scale 1:62500.

Brown, E. G., Laird, J., Pimlott, K. (2013). CALIFORNIA FOREST PRACTICE RULES 2013. fire.ca.gov. Retrieved from http://www.fire.ca.gov/resourcemanagement/pdf/FPR200401.pdf

Cal Fire (2009). Lockheed Fire Post Fire Risk Assessment. San Mateo-Santa Cruz Unit. California Department of Forestry and Fire Protection

Campbell, W. G., \& Morris, S. E. (1988). Hydrologic response of the Pack River, Idaho, to the Sundance Fire. Northwest Science, 62(4), 165-170. Retrieved from http://www.csa.com/partners/viewrecord.php?requester=gs\&amp;collection=ENV\& amp;recid=2370695

Conaway, C. H., Draut, A. E., Echols, K. R., Storlazzi, C. D. and Ritchie, A. (2012). Episodic Suspended Sediment Transport and Elevated Polycyclic Aromatic Hydrocarbon Concentrations in a Small, Mountainous River in Coastal California. River Research and Applications. www.wileyonlinelibrary.com 
DeBano, L. F., (2000). The role of fire and soil heating on water repellency in wildland environments: a review. Journal of Hydrology, Volumes 231-232, Pages 195-206. http://www.sciencedirect.com/science/article/pii/S0022169400001943

Doerr, S. H., Shakesby, R. A., \& MacDonald, L. H. (2010). Soil water repellency: A key factor in post-fire erosion. Fire effects on soils and restoration strategies, 2(1). Retrieved from http://ralph.swansea.ac.uk/hydrophobicity/papers/FireBook_Doerr_etal_preprint.pdf

Fiori, R. A. (2005). In-Stream and Riparian Dynamics Following Wildfire in an Alluvial Old- Growth Redwood Forest Canoe Creek , Humboldt Redwoods State Park InStream and Riparian Dynamics Following Wildfire in an Alluvial Old- Growth Redwood Forest - Canoe Creek, Humboldt, CA

Gaedeke, M. C. (2006). Preharvest Calibration of the Little Creek Watershed: A Paired and Nested Watershed Analysis. Master's Thesis. California Polytechnic State University, San Luis Obispo, CA.

Greenlee, J. M., \& Langenheim, J. H. (1990). Historic Fire Regimes and Their Relation to Vegetation Patterns in the Monterey Bay Area of California. American Midland Naturalist, 124(2), 239.

Helvey, J. D. (1980). Effects of a North Central Washington Wildfire on Runoff and Sediment Production. Journal of the American Water Resources Association, 16(4), 627-634.

Hewlett, J.D. and Hibbert, A.R. (1967). Factors affecting the response of small watersheds to precipitation in humid areas. Forest Hydrology, W.E. Sopper and H.W. Lull (Editors), Pergamon Press, Oxford, England: 275-290.

Hubbert, K., \& Wohlgemuth, P. (2008). Pre-and Postfire Distribution of Soil Water Repellency in a Steep Chaparral Watershed. USDA Forest Service Gen. Tech. Retrieved from http://www.fs.fed.us/psw/publications/documents/psw_gtr189/psw_gtr189a.pdf\#pag $\mathrm{e}=109$

Hudak, A., Robichaud, P., Evans, J., \& Clark, J. (2004). Field validation of Burned Area Reflectance Classification (BARC) products for post fire assessment. Retrieved from http://digitalcommons.unl.edu/usdafsfacpub/220/

Huffman, L., Forest, A. N., \& Collins, F. (2001). Strength hydrophobicity and persistence Front of fire-induced and lodgepole soil under Colorado ponderosa. Hydrological Processes, 2892(April), 2877-2892. 
Ice, G. G., Neary, D. G., \& Adams, P. W. (2004). Effects of wildfire on soils and watershed processes. Journal of Forestry, 102(6), 16-20. Retrieved from http://www.ingentaconnect.com/content/saf/jof/2004/00000102/00000006/art00004

Keller, E. a., Valentine, D. W., \& Gibbs, D. R. (1997). Hydrological Response of Small Watersheds Following the Southern California Painted Cave Fire of June 1990. Hydrological Processes, 11(4), 401-414.

Kunze, M. D., \& Stednick, J. D. (2006). Streamflow and suspended sediment yield following the 2000 Bobcat fire, Colorado. Hydrological Processes, 20(8), 16611681.

Larsen, I. J., MacDonald, L. H., Brown, E., Rough, D., Welsh, M. J., Pietraszek, J. H., Libohova, Z., et al. (2009). Causes of Post-Fire Runoff and Erosion: Water Repellency, Cover, or Soil Sealing? Soil Science Society of America Journal, 73(4), 1393.

Lau, N. (2011). Soil Hydrophobicity Testing in Little Creek Watershed. California Polytechnic State University, San Luis Obispo, CA. Unpublished.

Lerman,K. Ekern, M., Kozlowski, D. (2009). Early-Season Heavy Precipitation Event Northern/Central California and Western Nevada October 13 - 14, 2009. http://www.cnrfc.noaa.gov/storm_summaries/oct2009storm.php

Lewis, J., (1996). Turbidity-controlled suspended sediment sampling for runoff-event load estimation. Water Resources Research, 32(7); 2299-2310.

Lewis, J., Eads, R. E., (2009) Implementation guide for turbidity threshold sampling: principles, procedures, and analysis. Gen. Tech. Rep. PSW-GTR-212. Albany, CA: U.S. Department of Agriculture, Forest Service, Pacific Southwest Research Station. $87 \mathrm{p}$.

Lewis, J., Mori, S.R., Keppeler, E.T., and R.R. Ziemer, (2001). Impact of logging on storm peak flows, flow volumes, and suspended sediment loads in Caspar Creek, California. In Land use and Watersheds: Human influence on hydrology and geomorphology in urban and forest areas, M.S. Wigmosta and S.J. Burgoa, American Geophysical Union, Washington, D.C.: 85-126.

Lewis, J., (2011) Statistical analysis of changes in sediment and streamflow associated with logging and fire in the Little Creek watershed, Swanton-Pacific Ranch. Unpublished.

Montgomery, D. R., \& Buffington, J. M. (1997). Channel-reach morphology in mountain drainage basins. Geological Society Of America Bulletin, 109, 596- 611. 
Moody, J. A., \& Martin, D. A. (2001a). Initial hydrologic and geomorphic response following a wildfire in the Colorado Front Range. Earth Surface Processes and Landforms, 26(10), 1049-1070. doi:10.1002/esp.253

Moody, J. A., \& Martin, D. A. (2001b). Post-fire , rainfall intensity - peak discharge relations for three mountainous watersheds in the western USA. Hydrological Processes, 2993(July), 2981- 2993.

Neter, J., Kutner, M. H., Nachtsheim, C. J., Wasserman, W. (1996). Applied Linear Statistical Models. McGraw-Hill Companies, Inc. $4^{\text {th }}$ edition.

Niebrugge L. (2012). Assessment of site and soil characteristics of rill erosion following the Lockheed Fire in the Little Creek Watershed, Swanton Pacific Ranch. Master's thesis, California Polytechnic State University, San Luis Obispo, CA.

NRCS, USDA. Soil Web Survey. Accessed on November 5, 2012. http://websoilsurvey.nrcs.usda.gov/app/WebSoilSurvey.aspx

Parsons, A., \& Robichaud, P. (2003). Soil Burn Severity Definitions and Mapping Guidelines Soil Burn Severity Definitions and Mapping Guidelines. International Journal Of Wildland Fire, 1-12.

Perkins, D. (2007) Rainfall Intensity and Erosivity Calculation and Comparison with Suspended Sediment Load in the North Fork of Little Creek. California Polytechnic State University, San Luis Obispo, Ca. Unpublished.

Perkins, D. A. (2012) EVALUATING GEOMORPHIC CHANGE IN LITTLE CREEK USING REPEATED CROSS-SECTIONAL AND LONGITUDINAL PROFILE SURVEYS. Master's thesis, California Polytechnic State University, San Luis Obispo, CA

Pierson, F. B., Robichaud, P. R., Spaeth, K. E., Moffet, C. A. (2003). Impacts of fire on hydrology and erosion in steep mountain big sagebrush communities. First interagency conference on research in the watersheds: October 27-30, 2003. [Washington, D.C.]: U.S. Dept. of Agriculture, Agricultural Research Service: 625630.

R Development Core Team, 2010. R: A Language and Environment for Statistical Computing. Vienna: R Foundation for Statistical Computing. http://www.Rproject.org.

Renard, K. G., G. R. Foster, G. A. Weesies, D. K. McCool, and D. C. Yoder, coordinators. (1997). Predicting Soil Erosion by Water: A guide to Conservation Planning With the Revised Universal Soil Loss Equation (RUSLE). U.S. Department of Agriculture, Agriculture Handbook No. 703, 404 pp. 
Reneau, S. L., Katzman, D., Kuyumijan, G. A., Lavine, A., \& Malmon, D. V. (2007). Sediment delivery after a wildfire. Geology, 35(2), 151. doi: 10.1130/G23288A.1

Robichaud, Peter R.; Brown, Robert E. (2002). Silt fences: an economical technique for measuring hillslope soil erosion. Gen. Tech. Rep. RMRS-GTR-94. Fort Collins, CO: U.S. Department of Agriculture, Forest Service, Rocky Mountain Research Station. $24 \mathrm{p}$.

Robichaud, P., Lewis, S., \& Ashmun, L. (2008). New Procedure for Sampling Infiltration to Assess Post-fire Soil Water Repellency. USDA Forest Service Research Note $R M R S-R N-33$. Retrieved from http://forest.moscowfsl.wsu.edu/engr/library/Robichaud/Robichaud2008a/2008a.pdf

Robichaud, P. R. (2000). Forest fire effects on hillslope erosion: what we know. Watershed Management Council Networker, 9(1), 9-13. Retrieved from http://scholar.google.com/scholar?hl=en\&btnG=Search\&q=intitle:Forest+Fire+Effe cts+on+Hillslope+Erosion+:+What+We+Know\#0

Ryan, S. E., Dwire, K. A., \& Dixon, M. K. (2011). Impacts of wildfire on runoff and sediment loads at Little Granite Creek, western Wyoming. Geomorphology, 129(12), 113-130.

Scotts Creek Watershed Council. Scotts Creek Watershed Assessment. (2005). ftp://ftpdpla.water.ca.gov/users/prop50/10045_SantaCruz/Work\%20Plan\%20CD\%2 013/reference\%20plans\%20and\%20background\%20information/Scotts\%20Creek\% 20Watershed\%20Enhancement\%20Plan/SCWEP\%20Vol.1.pdf

Smith, H. G., Sheridan, G. J., Lane, P. N. J., Noske, P. J., \& Heijnis, H. (2011). Changes to sediment sources following wildfire in a forested upland catchment, southeastern Australia. Hydrological Processes.

Spigel, K. M., \& Robichaud, P. R. (2007). First-year post-fire erosion rates in Bitterroot National Forest, Montana. Hydrological processes, 21(8), 998-1005.

Spittler, T. (1995). Fire and the debris flow potential of winter storms. Brushfires in California: Ecology and Resource. Retrieved from http://www.werc.usgs.gov/seki/pdfs/Splittler_Fire-and_Debris_Flow_Winter.pdf

Stephens, S. L., \& Fry, D. L. (2005). Fire History in Coast Redwood Stands in the Northeastern Santa Cruz Mountains, California. Fire Ecology, 1(1), 2-19.

Stoof, C. R., Vervoort, R. W., Iwema, J., van den Elsen, E., Ferreira, a. J. D., \& Ritsema, C. J. (2012). Hydrological response of a small catchment burned by experimental fire. Hydrology and Earth System Sciences, 16(2), 267-285. 
Swanton Pacific Ranch (2004). General Management Plan (2004). http://www.spranch.org/forest_management.ldml

Turnipseed, D.P., and Sauer, V.B., 2010, Discharge measurements at gaging stations: U.S. Geological Survey Techniques and Methods, book 3, chap. A8, 87 p. (Also available at http://pubs.usgs.gov/tm/tm3-a8/.)

Wentworth, C., Knifong, D., Graymer, R., \& Blissenbach, J. (n.d.). DEPARTMENT OF THE INTERIOR GEOLOGIC MAP OF SANTA CRUZ COUNTY , CALIFORNIA. Mines and Geology Bulletin, 489-489.

White, R. A. (2010). Accuracy of Forest Road and Stream Channel Characteristics Derived From LiDAR in Forested Mountain Conditions. Master's thesis, California Polytechnic University, San Luis Obispo, CA.

Williams, G. P., 1989. Sediment concentration versus water discharge during single hydrologic events in rivers. Journal of Hydrology, vol. 111: 89-106. 


\section{APPENDICES}




\section{Appendix A. Soil Burn Severity Descriptive Classes As Described By Parsons and Robichaud (2003):}

Soil Burn Severity: Soil burn severity is a term that qualitatively describes classes of fire-caused changes to soil hydrologic function, as evidenced by soil characteristics and surface fuel and duff consumption. Large diameter down, woody fuels and organic soil horizons are consumed during long-term, smoldering and glowing combustion. The amount of duff or organic layer reduction is also called depth of burn, or ground char (Ryan and Noste 1985, as cited by the Fire Effects Guide). The amount and duration of subsurface heating determine the degree of soil burn severity, and can be inferred from fire effects on ground fuels (plants other organic matter) and soils.

\section{Descriptive classes}

An example of a set of soil burn severity classes is given below, in narrative as well as tabular format [See back of this paper]. Users must recognize that these are guidelines to visual indicators only, and the boundaries between the classes often become "blurred" in real world situations.

(a) Unburned to very low soil burn severity. Fire has not entered the area, or has very lightly charred only the litter and fine fuels on the ground; soil organic matter, structure, and infiltration unchanged.

(b) Low soil burn severity. Low soil heating or light ground char occurs; mineral soil is not changed; leaf litter may be charred or partially consumed, and the surface of the duff may be lightly charred; original forms of surface materials, such as needle litter or lichens may be visible; very little to no change in runoff response. Indicators include very small 
diameter ( $<1 / 4$ inch) foliage and twigs are consumed, some small twigs may remain; generally, foliage may be yellow; the surface is mostly black in a grassland or shrubland ecosystem, but some gray ash may be present; above-ground portions of vegetation may be consumed, but root masses are intact. Change in runoff response is usually slight.

(c) Moderate soil burn severity. Moderate soil heating with moderate ground char; soil structure is usually not altered; decreased infiltration due to fire-induced water repellency4 may be observed; litter and duff are deeply charred or consumed; shallow light colored ash layer and burned roots and rhizomes are usually present. Indicators include understory foliage, twigs ( $1 \frac{1}{4}$ to $3 / 4$ inch) are consumed; rotten wood and larger diameter woody debris are deeply charred or partially consumed; on shrubland sites, gray or white ash is present and char can be visible in the upper $1 \mathrm{~cm}$ of mineral soil, but the soil is not altered; in forested ecosystems, brown needles or leaves may remain (but not always) on overstory trees—-these are important as mulch, and should play a role when identifying treatment candidate sites; increase in runoff response may be moderate to high, depending on degree of fire-caused changes to the pre-fire vegetation community, density of pre-fire vegetation, and presence or absence of mulch potential, sprouting vegetation, etc.

(d) High soil burn severity. High soil heating, or deep ground char occurs; duff is completely consumed; soil structure is often destroyed due to consumption of organic matter; decreased infiltration due to fire-induced water repellency is often observed over a significant portion of the area; top layer of mineral soil may be changed in color (but not always) and consistence and the layer below may be blackened from charring of organic matter in the soil; deep, fine ash layer is present, often gray or white; all or most 
organic matter is removed; essentially all plant parts in the duff layer are consumed; increase in runoff response is usually high. Other indicators include large fuels $>3 / 4$ inch including major stems and trunks are consumed or heavily charred. On a shrub site, shrub stems and root crowns are often consumed. In forested ecosystems, generally no leaves or needles remain on standing trees; high soil burn severity areas are primary treatment candidate sites if there are downstream values at risk; 


\section{Appendix B. Little Creek Soil Map and Soil Descriptions}

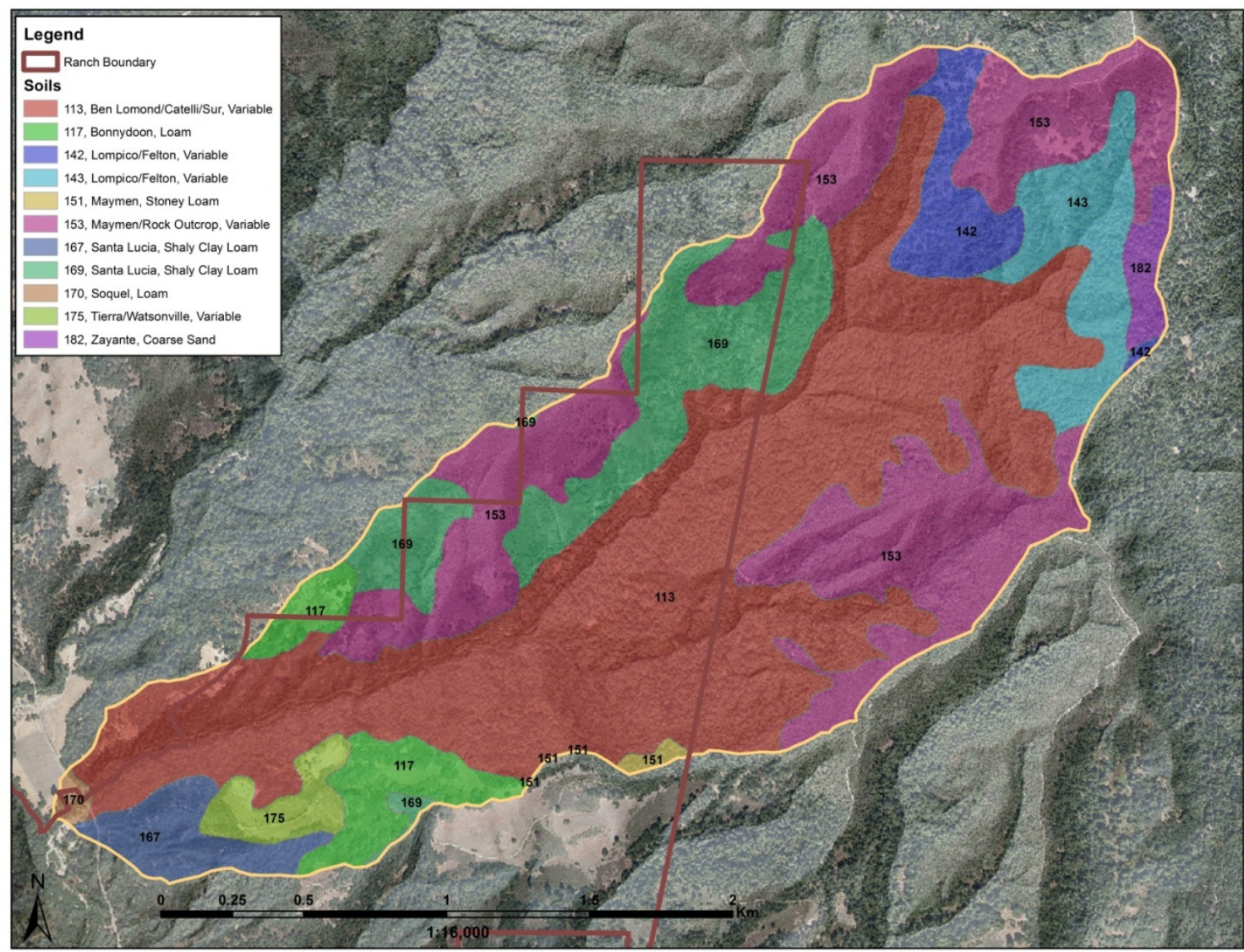


Appendix C. Little Creek Monitoring Station Rating Curves 


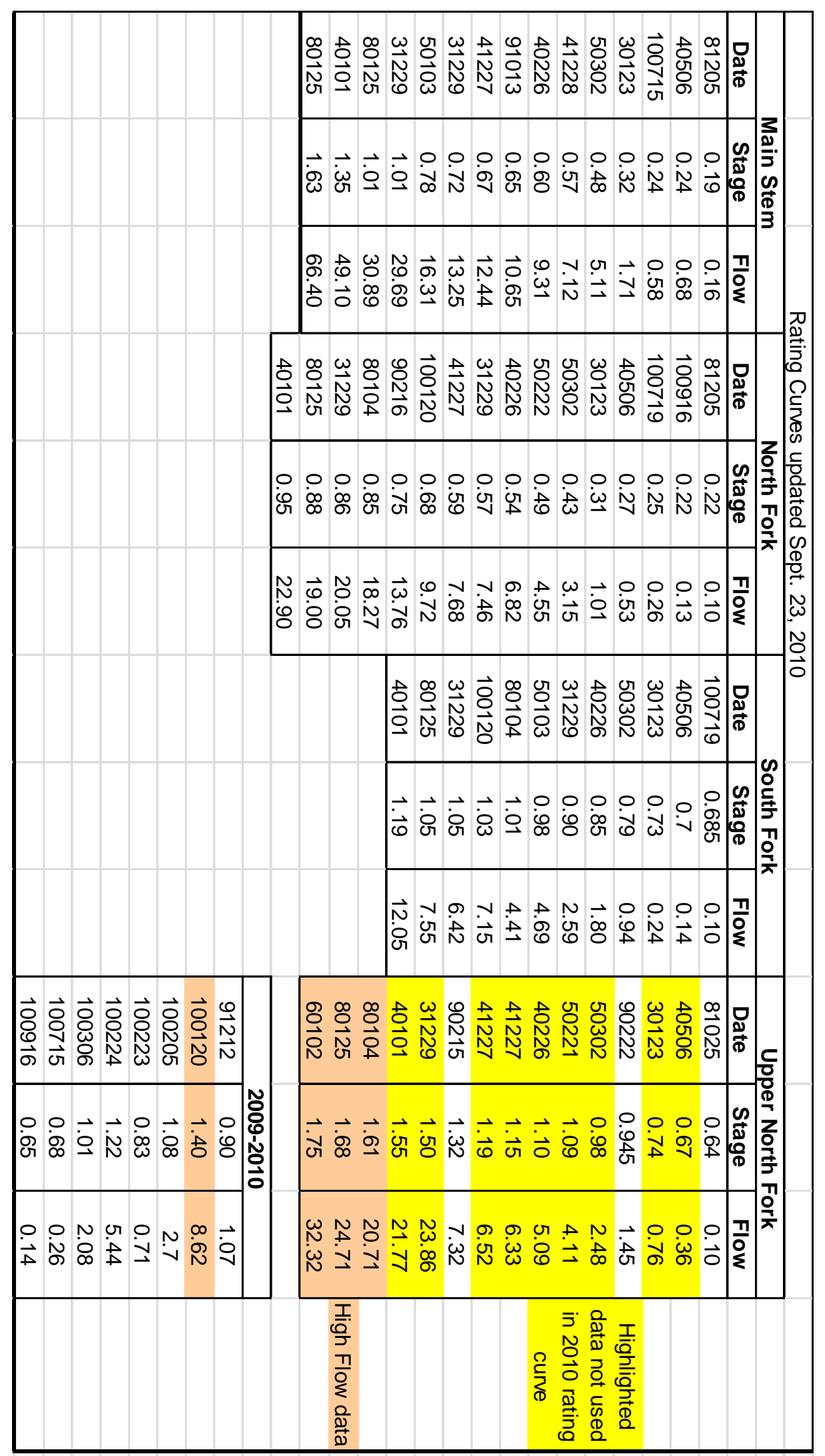



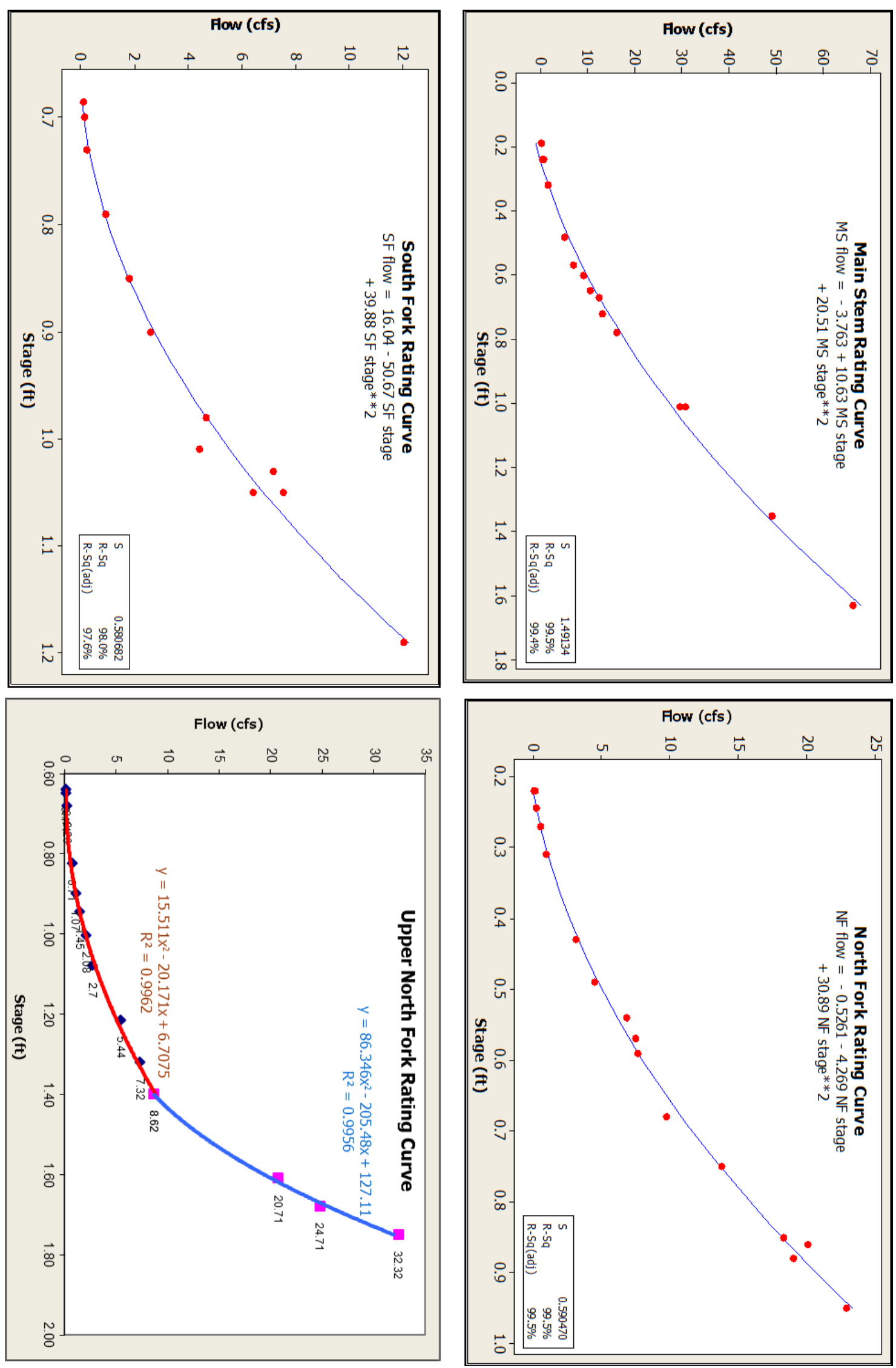


\section{Appendix D. Rainfall Simulator Data/Graphs}

\section{Site 4 - Little Creek Control}

Location:

Date:

Time:

Slope:

Area: $0.819 \mathrm{~m}^{2}$

$10 / 28 / 2009$

$14: 45$
Vegetation:

Soils:

understory.

Approximately 600' downstream of 4WD road along Little Creek Road. 30' downslope from road edge below RW clump. Approximately 70' from Little Creek. Unburned

70 percent

4" thick duff layer. Soil mudstone based and has many gravel to small cobble sized rocks. Many roots.

Calibration:

\begin{tabular}{|c|c|c|c|c|c|}
\hline Time on & 0.5 & 0.9 & & & \\
\hline Time off & 0.5 & 0.1 & & & \\
\hline Volume 1 & $310 \mathrm{~mL} / 30 \mathrm{~s}$ & $470 \mathrm{~mL} / 30 \mathrm{~s}$ & & & \\
\hline Volume 2 & $308 \mathrm{~mL} / 30 \mathrm{~s}$ & $467 \mathrm{~mL} / 30 \mathrm{~s}$ & & \multicolumn{2}{|r|}{ Slope Corrected Rainfall Rate: } \\
\hline Volume 3 & $315 \mathrm{~mL} / 30 \mathrm{~s}$ & $485 \mathrm{~mL} / 30 \mathrm{~s}$ & & $1.79 \mathrm{in} / \mathrm{hr}$ & $2.75 \mathrm{in} / \mathrm{hr}$ \\
\hline \multirow[t]{16}{*}{ Volume 4} & & $488 \mathrm{~mL} / 30 \mathrm{~s}$ & & $0.62 \mathrm{~L} / \mathrm{min}$ & $0.96 \mathrm{~L} / \mathrm{min}$ \\
\hline & time (min) & $\begin{array}{c}\text { Bucket } \\
\text { Water Depth } \\
\text { (in) }\end{array}$ & $\begin{array}{c}\text { Rainf } \\
\text { all } \\
\text { Volu } \\
\text { me } \\
\text { (L) }\end{array}$ & $\begin{array}{c}\text { Runoff } \\
\text { Volume (L) }\end{array}$ & Notes \\
\hline & 0 & -0.23 & 0.00 & 0.03 & $2.75 \mathrm{in} / \mathrm{hr}$ \\
\hline & 8 & -0.07 & 7.64 & 0.25 & \\
\hline & 10 & 0.08 & 9.55 & 0.46 & \\
\hline & 12 & 0.24 & 11.46 & 0.68 & leveled bucket \\
\hline & 14 & 0.48 & 13.37 & 1.01 & \\
\hline & 16 & 0.60 & 15.28 & 1.17 & $62 \mathrm{~mL} / 30 \mathrm{~s}$ \\
\hline & 18 & 0.75 & 17.19 & 1.39 & \\
\hline & 20 & 0.99 & 19.10 & 1.72 & \\
\hline & 23 & 1.27 & 21.97 & 2.11 & \\
\hline & 25 & 1.54 & 23.88 & 2.49 & \\
\hline & 26 & & 24.83 & & $65 \mathrm{~mL} / 30 \mathrm{~s}$ \\
\hline & 28 & 1.74 & 26.74 & 2.77 & \\
\hline & 29 & & 27.70 & & Stop Rain \\
\hline & 36 & 1.94 & & 3.05 & \\
\hline
\end{tabular}




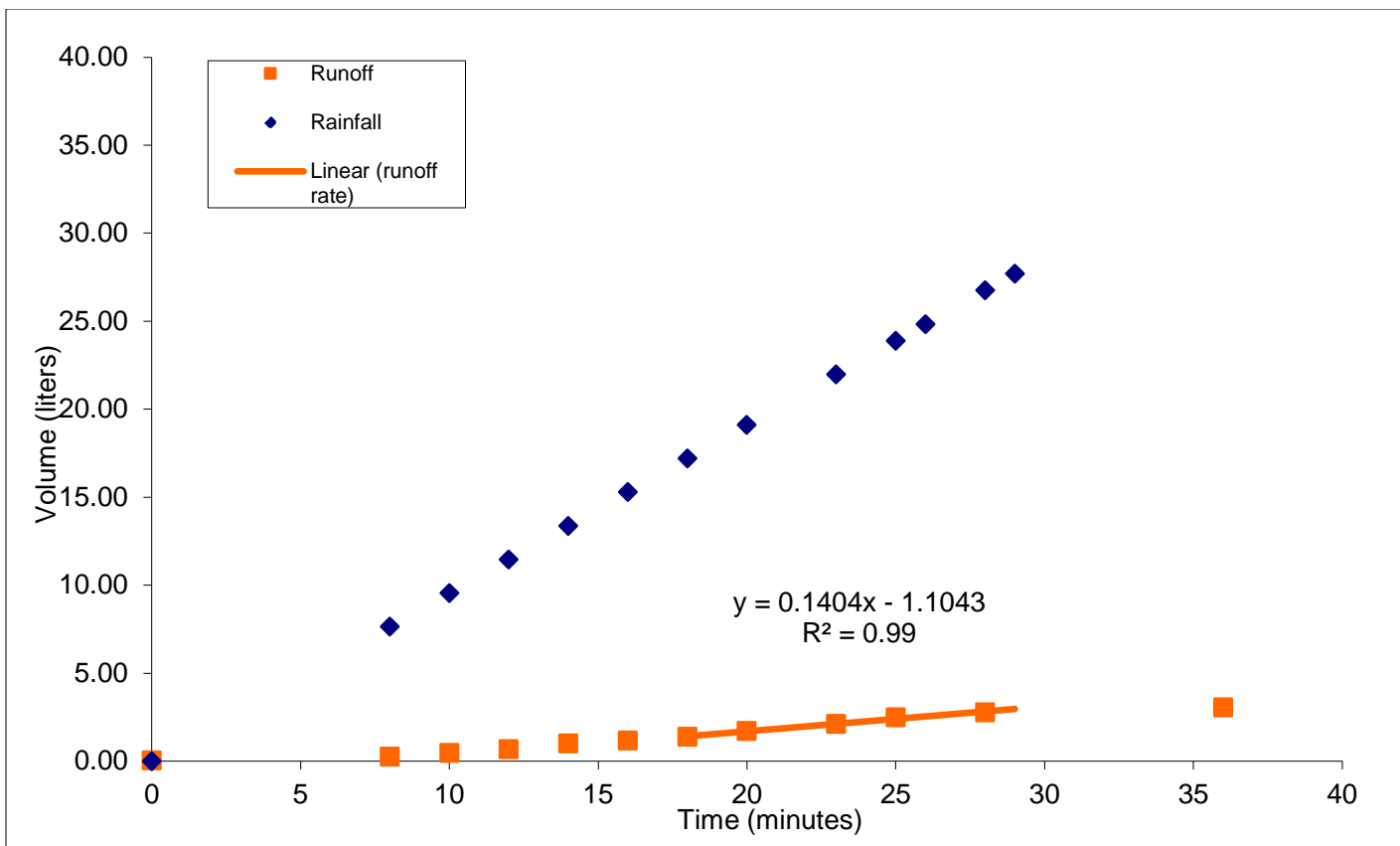

\begin{tabular}{|c|c|c|c|c|c|}
\hline Total Rain: & $27.70 \mathrm{~L}$ & & Rainfall Rate: & $\begin{array}{c}0.62 \\
\mathrm{~L} / \mathrm{min} \\
0.14\end{array}$ & $2.75 \mathrm{in} / \mathrm{hr}$ \\
\hline Total Runoff: & $3.05 \mathrm{~L}$ & 1.33 in & Runoff Rate: & $\mathrm{L} / \mathrm{min}$ & $0.40 \mathrm{in} / \mathrm{hr}$ \\
\hline Runoff Ratio: & 0.11 & 0.15 in & Infiltration $\mathrm{Ra}$ & $\begin{array}{c}0.48 \\
\mathrm{~L} / \mathrm{min}\end{array}$ & $2.35 \mathrm{in} / \mathrm{hr}$ \\
\hline
\end{tabular}

Results: 26 minutes @ 2.75 in/hr: runoff after 6 minutes of rain; most runoff from duff layer, minimal evidence of runoff in soil; soil moist in middle of plot after simulator indicating good infiltration. 
Site 5 - Cabins

Location: 400' up road from crossing R8 on Little Creek Road. 20' upslope from edge of road cut. Near intersection of trail/old road and haul road.

Date:

Time:

Slope:

Area:

\begin{tabular}{|l|}
\hline $10 / 29 / 2009$ \\
\hline $11: 55$ \\
\hline $0.854 \mathrm{~m}^{2}$
\end{tabular}

Vegetation:

Douglas-fir, bay, oak; south aspect; low to medium burn

Soils: Sandstone parent material with some mudstone colluvium. $50 \%$ coverage by DF/bay/oak leaf litter. $10 \%$ rock fragments at surface. Common soil pedestals.

Calibration:

\begin{tabular}{|c|c|c|}
\hline Time on & 0.6 & 0.1 \\
\hline Time off & 0.4 & 0.9 \\
\hline Volume 1 & $365 \mathrm{~mL} / 30 \mathrm{~s}$ & $118 \mathrm{~mL} / 30 \mathrm{~s}$ \\
\hline Volume 2 & $370 \mathrm{~mL} / 30 \mathrm{~s}$ & $120 \mathrm{~mL} / 30 \mathrm{~s}$ \\
\hline Volume 3 & $370 \mathrm{~mL} / 30 \mathrm{~s}$ & $115 \mathrm{~mL} / 30 \mathrm{~s}$ \\
\hline
\end{tabular}

\begin{tabular}{cc} 
& $\begin{array}{l}\text { Slope Corrected } \\
\text { Rainfall Rate: }\end{array}$ \\
\hline $\mathbf{2 . 0 4} \mathrm{in} / \mathrm{hr}$ & $\mathbf{0 . 6 5} \mathrm{in} / \mathrm{hr}$ \\
$0.74 \mathrm{~L} / \mathrm{min}$ & $0.24 \mathrm{~L} / \mathrm{min}$
\end{tabular}

\begin{tabular}{ccccl} 
time (min) & $\begin{array}{c}\text { Bucket } \\
\text { Water } \\
\text { Depth (in) }\end{array}$ & $\begin{array}{c}\text { Rainfall } \\
\text { Volume } \\
(\mathbf{L})\end{array}$ & $\begin{array}{c}\text { Runoff } \\
\text { Volume } \\
(\mathbf{L})\end{array}$ & Notes \\
\hline 0 & 0 & 0.00 & 0.35 & rain $2.04 \mathrm{in} / \mathrm{hr}$ \\
2 & 0 & 1.47 & 0.35 & \\
6 & 0 & 4.42 & 0.35 & \\
14 & 0 & 10.31 & 0.35 & start runoff - runoff only from top 1" of \\
16 & 0 & 11.79 & 0.35 & soil, below 1" dry. \\
18 & 0.4 & 13.26 & 0.90 & \\
20 & 0.8 & 14.73 & 1.46 & \\
23 & 1.6 & 16.94 & 2.58 & \\
24 & 1.9 & 17.68 & 3.00 & runoff rate $0.94 \mathrm{in} / \mathrm{hr}$ \\
26 & 2.3 & 19.15 & 3.57 & \\
28 & 2.8 & 20.63 & 4.28 & \\
30 & 3.4 & 22.10 & 5.14 & soil pedestals forming \\
32 & 4 & 23.57 & 6.01 & \\
34 & 4.4 & 25.05 & 6.59 & runoff rate $1.03 \mathrm{in} / \mathrm{hr}$ \\
36 & 4.9 & 26.52 & 7.33 & \\
38 & 5.4 & 27.99 & 8.07 & \\
40 & 5.9 & 29.47 & 8.81 & \\
41 & 6.3 & 29.70 & 9.41 & rain $0.65 \mathrm{in} / \mathrm{hr}$ \\
43 & 6.5 & 30.17 & 9.71 & \\
45 & 6.7 & 30.64 & 10.01 & \\
47 & 6.9 & 31.11 & 10.31 & \\
49 & 7.05 & 31.58 & 10.54 & \\
51 & 7.2 & 32.06 & 10.77 & \\
53 & 7.35 & 32.53 & 10.99 & \\
55 & 7.5 & 33.00 & 11.22 & \\
56 & 7.6 & 33.23 & 11.37 & \\
\hline & & & & \\
& & & & \\
& & & & \\
& & & &
\end{tabular}




\begin{tabular}{|c|c|c|}
\hline $\begin{array}{r}\text { Total Rain: } \\
\text { Total } \\
\text { Runoff: }\end{array}$ & $33.23 \mathrm{~L}$ & $1.53 \mathrm{in}$ \\
\hline Runoff: & $11.37 \mathrm{~L}$ & 0.52 in \\
\hline
\end{tabular}

\begin{tabular}{|c|c|c|}
\hline Rainfall Rate: & $0.74 \mathrm{~L} / \mathrm{min}$ & $2.04 \mathrm{in} / \mathrm{hr}$ \\
\hline Runoff Rate: & $0.37 \mathrm{~L} / \mathrm{min}$ & $1.03 \mathrm{in} / \mathrm{hr}$ \\
\hline $\begin{array}{r}\text { Infiltration } \\
\text { Rate: }\end{array}$ & $0.36 \mathrm{~L} / \mathrm{min}$ & $1.00 \mathrm{in} / \mathrm{hr}$ \\
\hline
\end{tabular}

(2)

\begin{tabular}{rrr} 
Rainfall Rate: & $0.24 \mathrm{~L} / \mathrm{min}$ & $0.65 \mathrm{in} / \mathrm{hr}$ \\
Runoff Rate: & $0.13 \mathrm{~L} / \mathrm{min}$ & $0.35 \mathrm{in} / \mathrm{hr}$ \\
\hline Infiltration & & \\
Rate: & $0.11 \mathrm{~L} / \mathrm{min}$ & $\mathbf{0 . 3 0} \mathrm{in} / \mathrm{hr}$
\end{tabular}

Results:

Top layer saturated (1" depth) and majority of runoff coming from 1st inch of soil, with little to no surface flow. Below 1" soil was dry.

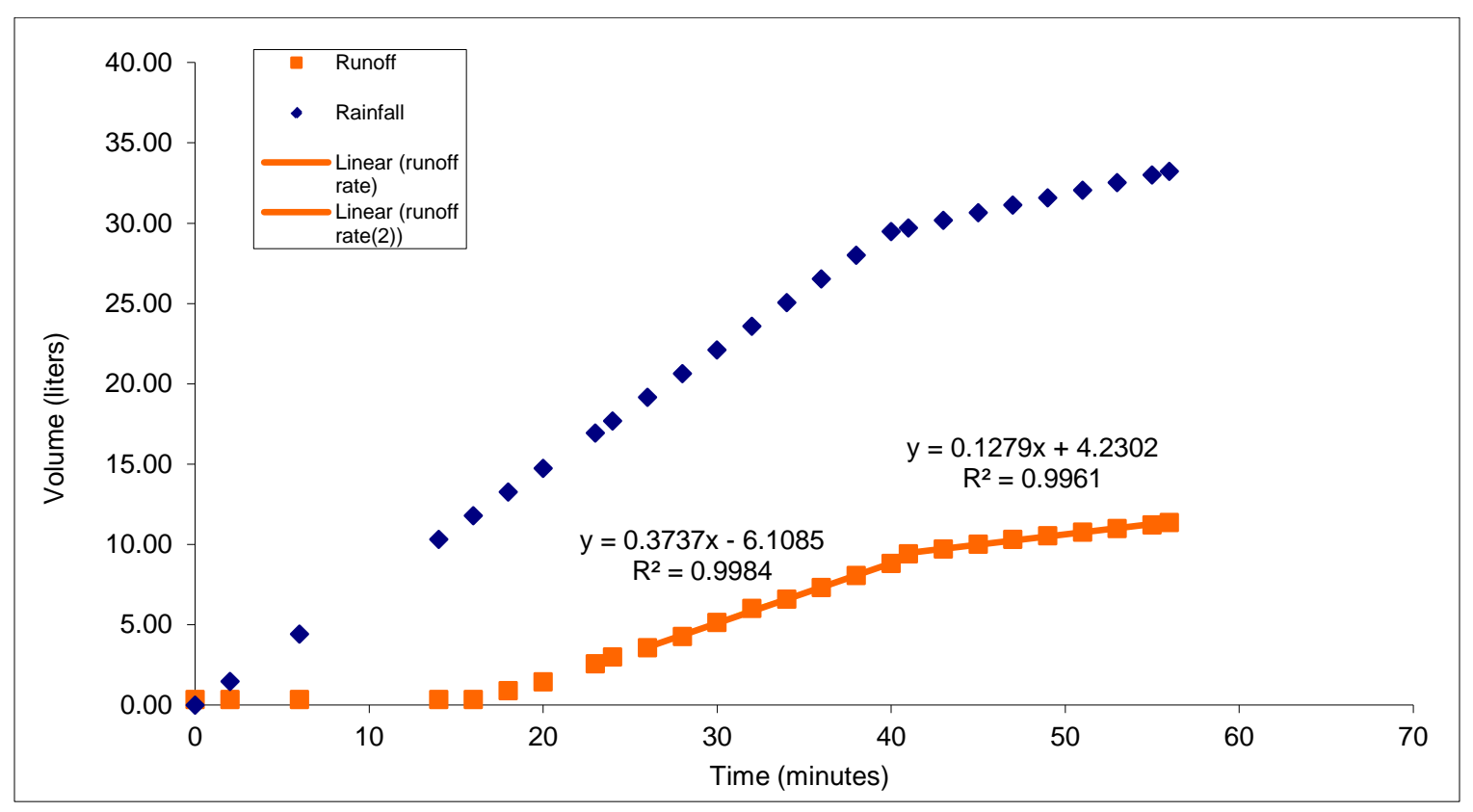


Site 6 - UNF

Location: Near UNF bridge directly uphill from top of trail to flume

Date: $10 / 30 / 2009$

Time: $12: 05$

Slope: $\quad 50$ percent

Area: $0.894 \mathrm{~m}^{2}$

Vegetation: Redwood/tanoak. Low burn intensity

Soils: Decomposed granite. High clay content. Initially moist no dry layer.

\section{Calibration:}

\begin{tabular}{rccccc}
\hline Time on & 0.8 & $\mathbf{0 . 6}$ & & \\
Time off & 0.2 & $\mathbf{0 . 4}$ & & \multicolumn{2}{c}{ Slope Corrected Rainfall Rate: } \\
${$\cline { 1 - 2 }$} }$ & $616 \mathrm{~mL} / 30 \mathrm{~s}$ & $435 \mathrm{~mL} / 30 \mathrm{~s}$ & & $\mathbf{3 . 1 3} \mathrm{in} / \mathrm{hr}$ & $\mathbf{2 . 3 2} \mathrm{in} / \mathrm{hr}$ \\
Volume 2 & $570 \mathrm{~mL} / 30 \mathrm{~s}$ & $438 \mathrm{~mL} / 30 \mathrm{~s}$ & & $1.18 \mathrm{~L} / \mathrm{min}$ & $0.88 \mathrm{~L} / \mathrm{min}$ \\
Volume 3 & $590 \mathrm{~mL} / 30 \mathrm{~s}$ & $442 \mathrm{~mL} / 30 \mathrm{~s}$ & & &
\end{tabular}

\begin{tabular}{|c|c|c|c|c|}
\hline time (min) & $\begin{array}{c}\text { Bucket } \\
\text { Water } \\
\text { Depth (in) }\end{array}$ & $\begin{array}{c}\text { Rainfall } \\
\text { Volume } \\
\text { (L) }\end{array}$ & $\begin{array}{c}\text { Runoff } \\
\text { Volume (L) }\end{array}$ & Notes \\
\hline 0 & & 0.00 & & Start \\
\hline 6.25 & 0.1 & 5.48 & 0.49 & \\
\hline 8 & 0.6 & 7.01 & 1.18 & \\
\hline 10 & 1 & 8.77 & 1.73 & \\
\hline 12 & 1.4 & 10.52 & 2.29 & \\
\hline 14.5 & 1.9 & 12.71 & 3.00 & \\
\hline 16 & 2.3 & 14.03 & 3.57 & \\
\hline 18 & 2.8 & 15.78 & 4.28 & \\
\hline 20 & 3.3 & 17.53 & 5.00 & \\
\hline 22 & 3.9 & 19.29 & 5.87 & \\
\hline 24 & 4.4 & 21.04 & 6.59 & \\
\hline 26 & 4.9 & 22.79 & 7.33 & \\
\hline 28 & 5.4 & 24.55 & 8.07 & \\
\hline 30 & 5.9 & 26.30 & 8.81 & \\
\hline 32 & 6.4 & 28.05 & 9.56 & \\
\hline 34 & 6.9 & 29.81 & 10.31 & \\
\hline 36 & 7.3 & 31.56 & 10.92 & \\
\hline 38 & 7.8 & 33.31 & 11.68 & \\
\hline 40 & 8.2 & 35.07 & 12.29 & \\
\hline 42 & 8.7 & 36.82 & 13.06 & \\
\hline 44 & 9.2 & 38.57 & 13.84 & \\
\hline 46 & 9.7 & 40.33 & 14.62 & \\
\hline 48 & 10.2 & 42.08 & 15.40 & \\
\hline 50 & 10.6 & 43.83 & 16.03 & \\
\hline 52 & 11.1 & 45.59 & 16.83 & \\
\hline 54 & 11.6 & 47.34 & 17.63 & Off \\
\hline
\end{tabular}




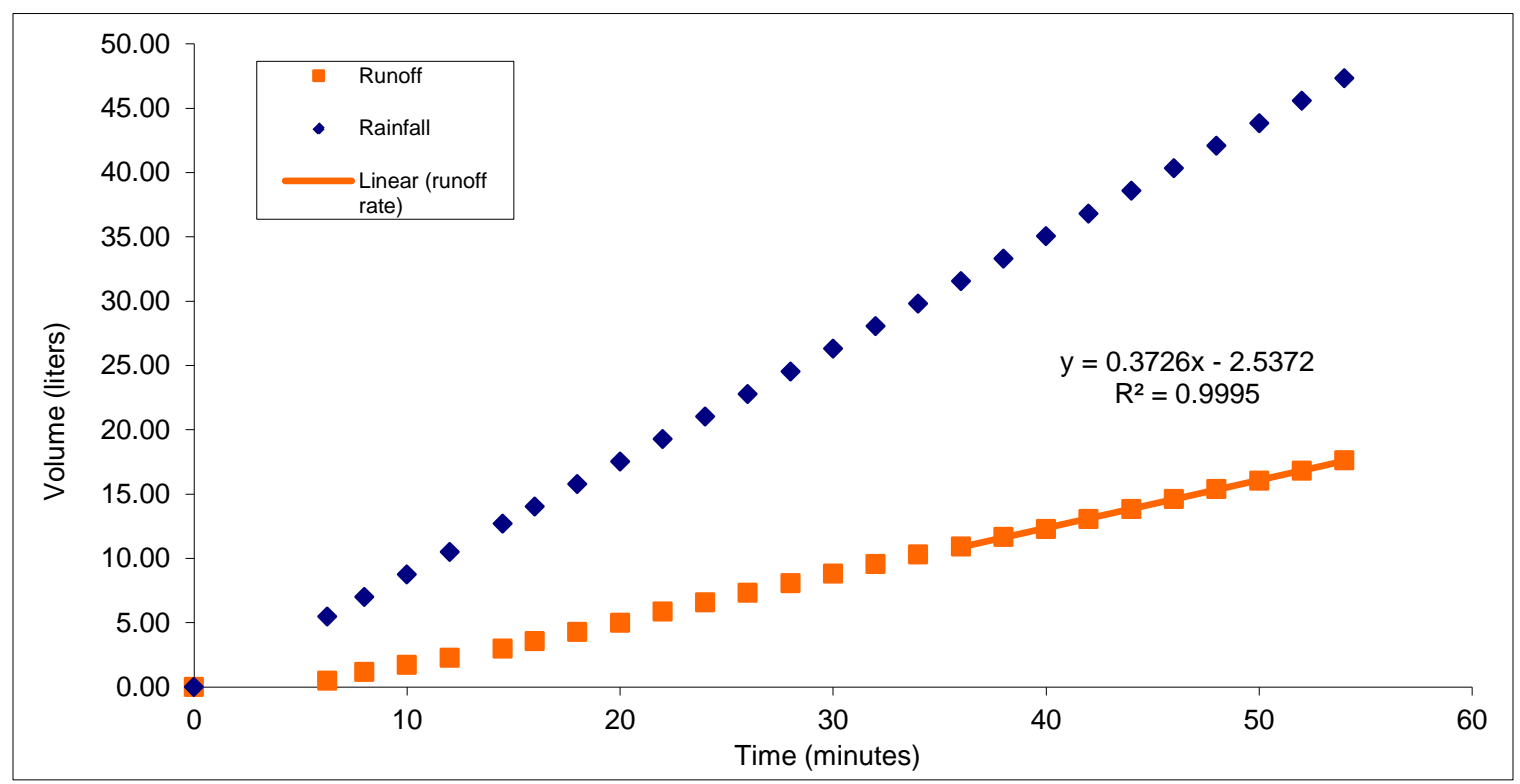

\begin{tabular}{|c|c|c|c|c|c|}
\hline Total Rain: & $47.34 \mathrm{~L}$ & $2.08 \mathrm{in}$ & Rainfall Rate: & $\begin{array}{c}0.88 \\
\text { L/min } \\
0.37\end{array}$ & $2.32 \mathrm{in} / \mathrm{hr}$ \\
\hline Total Runoff: & $17.63 \mathrm{~L}$ & 0.78 in & Runoff Rate: & $\mathrm{L} / \mathrm{min}$ & $0.98 \mathrm{in} / \mathrm{hr}$ \\
\hline Runoff Ratio: & & & $\begin{array}{l}\text { Infiltration } \\
\text { Rate: }\end{array}$ & $\begin{array}{l}0.50 \\
\mathrm{~L} / \mathrm{min}\end{array}$ & $1.33 \mathrm{in} / \mathrm{hr}$ \\
\hline
\end{tabular}

Results: Collector plate 1.5 to 2" deep at downhill end of plot. Observed runoff after 6 min of rainfall. Some surface flow was evident. Fairly consistent runoff rate. 
Site 7 - South Fork

Location: South Fork Little Creek approximately $150 \mathrm{ft}$. uphill from first landing in the redwoods.

Date: $11 / 2 / 2009$

Time: $13: 04$

Slope: 54 percent

Area: $0.880 \mathrm{~m}^{2}$

Vegetation: Redwood, Tan oak, Douglas-fir. Moderate burn intensity; scorch heights 3-10 ft. locally with $30 \mathrm{ft}$. plus within $50 \mathrm{ft}$.

Soils: Mudstone colluvium parent material.

Calibration:

\begin{tabular}{rrr}
\hline Time on & $\mathbf{0 . 6}$ & 0.9 \\
& & 0.1 \\
Time off & $\mathbf{0 . 4}$ & $670 \mathrm{~mL} / 30 \mathrm{~s}$ \\
Volume 1 & $397 \mathrm{~mL} / 30 \mathrm{~s}$ & $660 \mathrm{~mL} / 30 \mathrm{~s}$ \\
Volume 2 & $388 \mathrm{~mL} / 30 \mathrm{~s}$ & $660 \mathrm{~mL} / 30 \mathrm{~s}$ \\
Volume 3 & $405 \mathrm{~mL} / 30 \mathrm{~s}$ & 6 \\
\hline
\end{tabular}

Slope Corrected Rainfall Rate:

$\begin{array}{ll}2.13 \mathrm{in} / \mathrm{hr} & \mathbf{3 . 5 6} \mathrm{in} / \mathrm{hr} \\ 0.79 \mathrm{~L} / \mathrm{min} & 1.33 \mathrm{~L} / \mathrm{min}\end{array}$

\begin{tabular}{|c|c|c|c|c|}
\hline time (min) & $\begin{array}{l}\text { Bucket } \\
\text { Water } \\
\text { Depth } \\
\text { (in) }\end{array}$ & $\begin{array}{l}\text { Rainfall } \\
\text { Volume } \\
\text { (L) }\end{array}$ & $\begin{array}{c}\text { Runoff } \\
\text { Volume (L) }\end{array}$ & Notes \\
\hline 0 & & 0.00 & & Start \\
\hline 5 & 0 & 3.97 & 0.35 & \\
\hline 9 & 0.2 & 7.14 & 0.62 & \\
\hline 12 & 0.6 & 9.52 & 1.18 & \\
\hline 14 & 0.9 & 11.11 & 1.59 & \\
\hline 16 & 1.1 & 12.69 & 1.87 & \\
\hline 18 & 1.35 & 14.28 & 2.22 & \\
\hline 20 & 1.5 & 15.87 & 2.43 & \\
\hline 22 & 1.7 & 17.45 & 2.72 & \\
\hline 24 & 1.9 & 19.04 & 3.00 & \\
\hline 26 & 2.05 & 20.63 & 3.21 & \\
\hline 28 & 2.2 & 22.21 & 3.42 & \\
\hline 30 & 2.4 & 23.80 & 3.71 & \\
\hline 32 & 2.5 & 25.39 & 3.85 & \\
\hline 34 & 2.65 & 26.97 & 4.06 & \\
\hline 36 & 2.75 & 28.56 & 4.21 & \\
\hline 38 & 2.9 & 30.15 & 4.42 & \\
\hline 40 & 3 & 31.73 & 4.57 & \\
\hline 44 & 3.2 & 34.91 & 4.85 & \\
\hline 48 & 3.45 & 38.08 & 5.21 & \\
\hline 51 & 3.6 & 40.46 & 5.43 & \\
\hline 60 & 3.6 & 40.46 & 5.43 & Start $3.56 \mathrm{in} / \mathrm{hr}$ \\
\hline 63.5 & 3.6 & 45.10 & 5.43 & \\
\hline 65 & 4 & 47.09 & 6.01 & \\
\hline
\end{tabular}




\begin{tabular}{lccc}
67 & 4.4 & 49.75 & 6.59 \\
69 & 4.7 & 52.40 & 7.03 \\
71 & 5 & 55.05 & 7.48 \\
73 & 5.3 & 57.71 & 7.92 \\
75 & 5.6 & 60.36 & 8.36 \\
76 & 5.7 & 61.69 & 8.51 \\
\hline
\end{tabular}

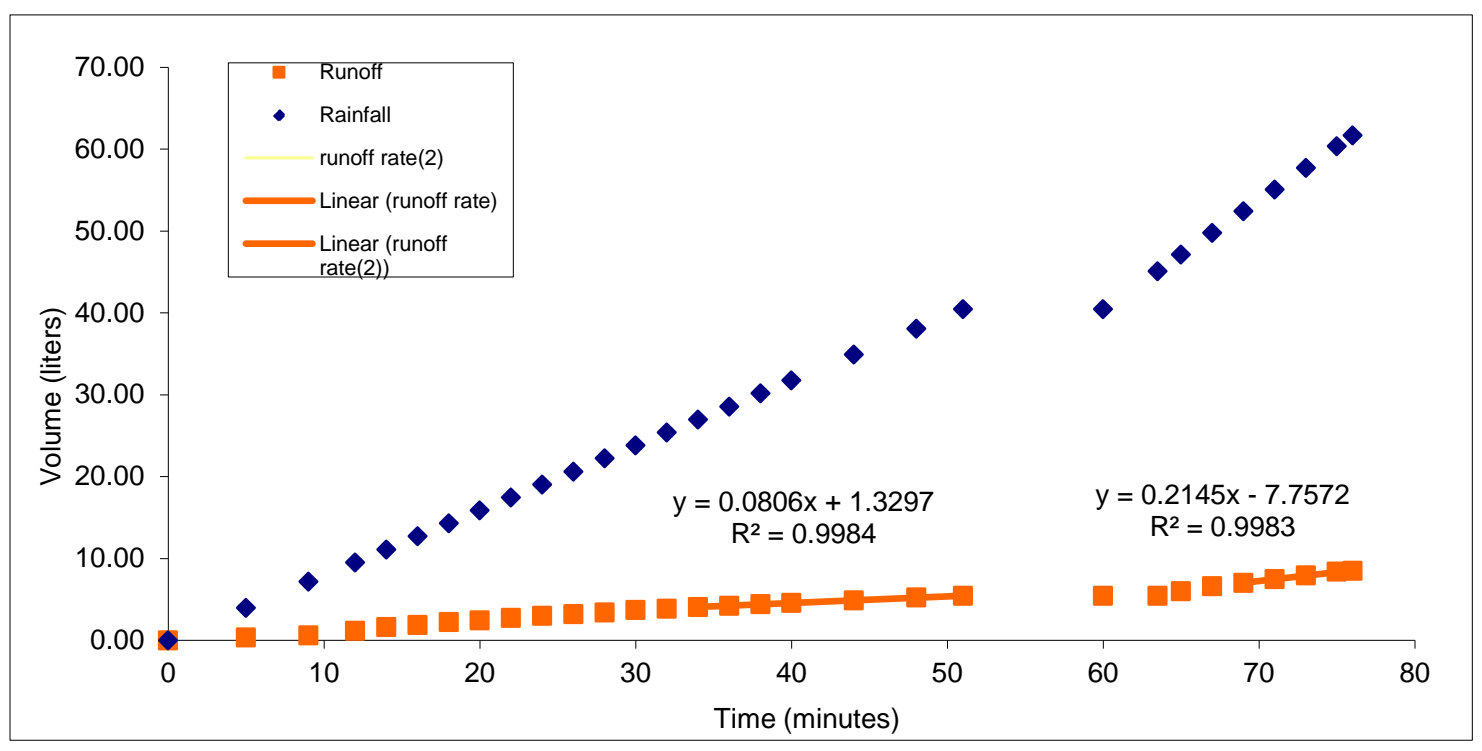

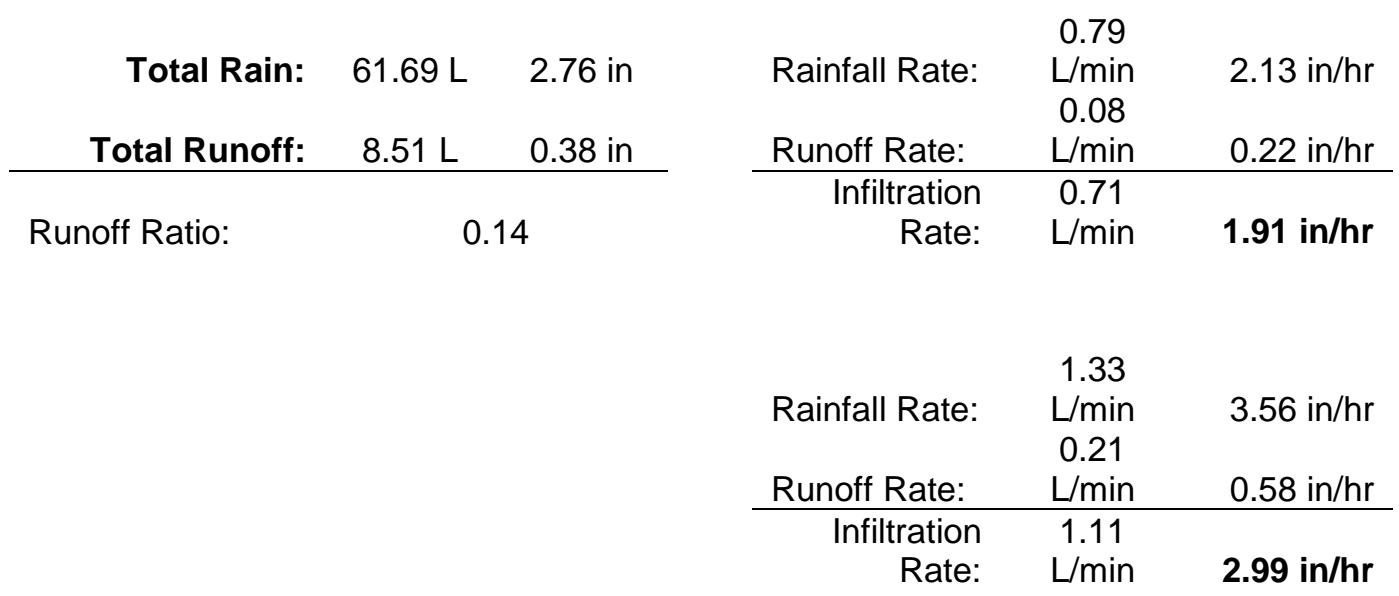

Results: Had constant runoff rate after 10 min. No evidence of surface runoff. Site appeared to have good infiltration capacity, although after rainfall about 5\% of plot had dry soil, possibly indicating hydrophobicity. 
Site 8 - Boyer

Location: Mill Creek/Boyer Creek ridgeline on south facing slope of Boyer Creek (Lockheed property). Very high burn intensity.

Date: $11 / 4 / 2009$

Time: $12: 30$

Slope: 60 percent

Area: $0.857 \mathrm{~m}^{2}$

Vegetation: Manzanita, Knobcone pine, scrub oak, (chaparral)

Soils: Shallow mudstone. 95\% of surface rock fragments.

Calibration:

\begin{tabular}{rrr}
\hline Time on & $\mathbf{0 . 8}$ & 0.6 \\
Time off & $\mathbf{0 . 2}$ & 0.4 \\
\hline Volume 1 & $420 \mathrm{~mL} / 30 \mathrm{~s}$ & $326 \mathrm{~mL} / 30 \mathrm{~s}$ \\
Volume 2 & $437 \mathrm{~mL} / 30 \mathrm{~s}$ & $345 \mathrm{~mL} / 30 \mathrm{~s}$ \\
Volume 3 & $445 \mathrm{~mL} / 30 \mathrm{~s}$ & $310 \mathrm{~mL} / 30 \mathrm{~s}$ \\
Volume 4 & $452 \mathrm{~mL} / 30 \mathrm{~s}$ & $307 \mathrm{~mL} / 30 \mathrm{~s}$ \\
Volume 5 & $455 \mathrm{~mL} / 30 \mathrm{~s}$ & $319 \mathrm{~mL} / 30 \mathrm{~s}$ \\
Volume 6 & & $300 \mathrm{~mL} / 30 \mathrm{~s}$ \\
\hline
\end{tabular}

Slope Corrected Rainfall Rate: $2.43 \mathrm{in} / \mathrm{hr} \quad 1.75 \mathrm{in} / \mathrm{hr}$ $0.88 \mathrm{~L} / \mathrm{min} \quad 0.64 \mathrm{~L} / \mathrm{min}$

\begin{tabular}{ccccl}
$\begin{array}{c}\text { Bucket } \\
\text { time } \\
\text { (min) }\end{array}$ & $\begin{array}{c}\text { Water } \\
\text { Depth } \\
\text { (in) }\end{array}$ & $\begin{array}{c}\text { Rainfall } \\
\text { Volume } \\
\text { (L) }\end{array}$ & $\begin{array}{c}\text { Runoff } \\
\text { Volume } \\
\text { (L) }\end{array}$ & Notes \\
\hline 0 & & 0.00 & & runoff @ 2 min \\
5.2 & 0 & 4.59 & 0.35 & \\
6 & 0.4 & 5.30 & 0.90 & \\
7 & 0.9 & 6.19 & 1.59 & \\
8 & 1.4 & 7.07 & 2.29 & \\
9 & 1.9 & 7.95 & 3.00 & \\
10 & 2.4 & 8.84 & 3.71 & \\
12 & 3.45 & 10.60 & 5.21 & \\
14 & 4.3 & 12.37 & 6.45 & \\
16.5 & 5.7 & 14.58 & 8.51 & \\
18 & 6.4 & 15.90 & 9.56 & \\
20 & 7.35 & 17.67 & 10.99 & \\
22 & 8.3 & 19.44 & 12.45 & \\
24 & 9.3 & 21.21 & 13.99 & \\
26 & 10.25 & 22.97 & 15.48 & $395 \mathrm{~mL} / 30 \mathrm{~s} @ 27$ \\
28 & 11.3 & 24.74 & 17.15 & \\
29.5 & 12 & 26.07 & 18.27 & \\
\hline
\end{tabular}




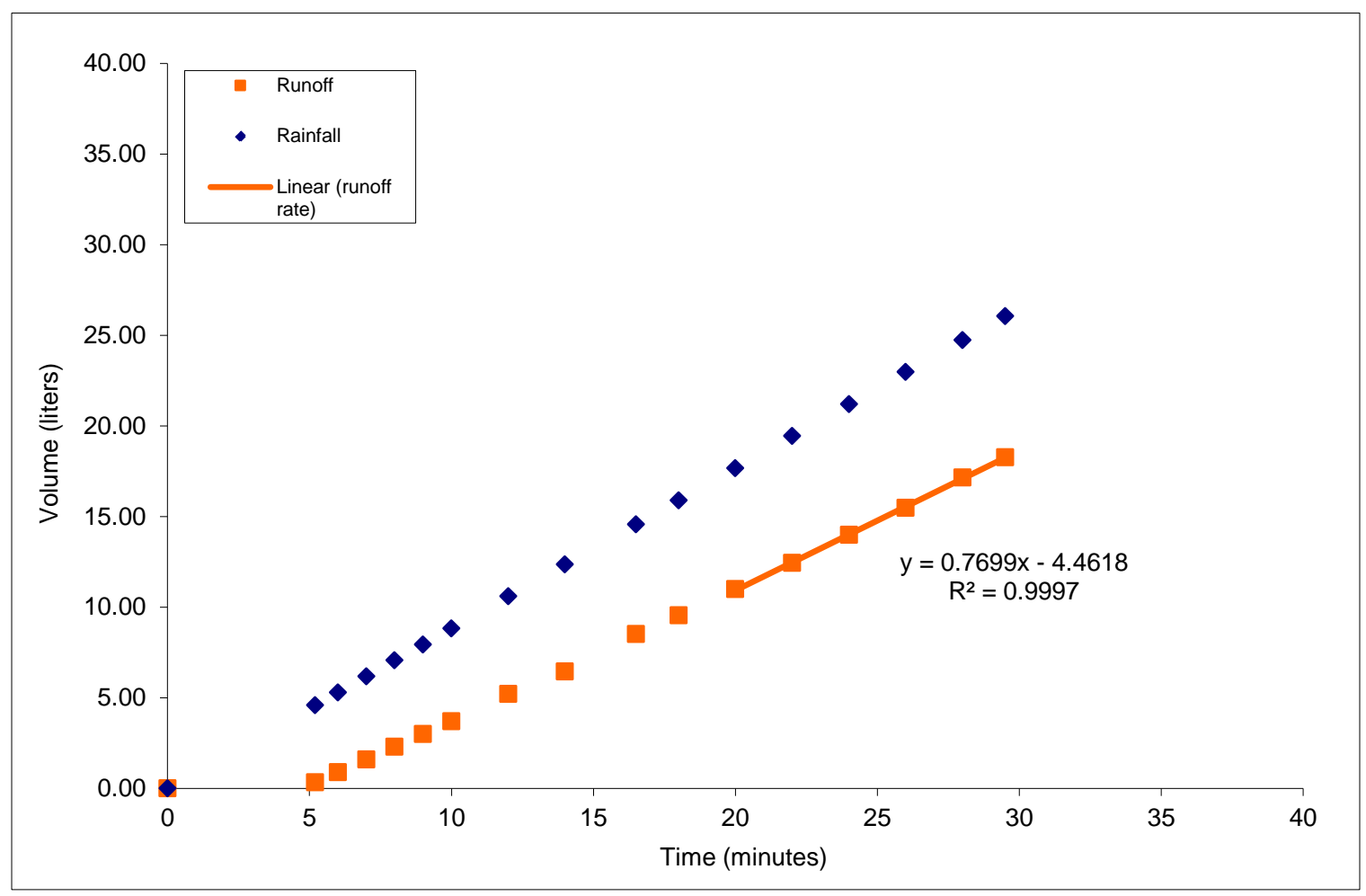

\begin{tabular}{|c|c|c|c|c|c|}
\hline $\begin{array}{r}\text { Total Rain: } \\
\text { Total }\end{array}$ & $26.07 \mathrm{~L}$ & 1.20 in & Rainfall Rate: & $\begin{array}{c}0.88 \\
\mathrm{~L} / \mathrm{min} \\
0.77\end{array}$ & $2.43 \mathrm{in} / \mathrm{hr}$ \\
\hline Runoff: & $18.27 \mathrm{~L}$ & 0.84 in & Runoff Rate: & $\mathrm{L} / \mathrm{min}$ & $2.12 \mathrm{in} / \mathrm{hr}$ \\
\hline $\begin{array}{l}\text { Runoff } \\
\text { Ratio: }\end{array}$ & & & $\begin{array}{l}\text { Infiltration } \\
\text { Rate: }\end{array}$ & $\begin{array}{l}0.11 \\
\text { L/min }\end{array}$ & $\begin{array}{r}0.32 \\
\text { in/hr }\end{array}$ \\
\hline
\end{tabular}

Results: Strong evidence of hydrophobicity. Very high runoff rate with little to no infiltration in half inch plus depth of soil. Top half inch of soil removed after rainfall exposing nothing but dry soil. 


\section{Site 9 - Mill Control}

Location: Lockheed ridge on top of Mill Creek and Boyer Creek watersheds on Boyer Creek side. Unburned control site. Near rectangular fenced area.

Date:

Time: $11 / 4 / 2009$

Slope:

Area: $0.876 \mathrm{~m}^{2}$

Vegetation: Manzanita, Knobcone pine, Doug-fir, oak, (chaparral)

Soils: Mudstone/sandstone, possibly at contact of two parent materials. Sandy loam soil.

Calibration:

\begin{tabular}{|c|c|c|c|}
\hline Time on & $\begin{array}{l}0.8 \\
0.2\end{array}$ & \multirow{2}{*}{\multicolumn{2}{|c|}{ Slope Corrected Rainfall Rate }} \\
\hline Volume 1 & $440 \mathrm{~mL} / 30 \mathrm{~s}$ & & \\
\hline Volume 2 & $470 \mathrm{~mL} / 30 \mathrm{~s}$ & $2.42 \mathrm{in} / \mathrm{hr}$ & - \\
\hline Volume 3 & $460 \mathrm{~mL} / 30 \mathrm{~s}$ & $0.90 \mathrm{~L} / \mathrm{min}$ & - \\
\hline Volume 4 & $445 \mathrm{~mL} / 30 \mathrm{~s}$ & & \\
\hline Volume 5 & $425 \mathrm{~mL} / 30 \mathrm{~s}$ & & \\
\hline Volume 6 & $448 \mathrm{~mL} / 30 \mathrm{~s}$ & & \\
\hline
\end{tabular}

\begin{tabular}{ccccl} 
time (min) & $\begin{array}{c}\text { Bucket } \\
\text { Water } \\
\text { Depth (in) }\end{array}$ & $\begin{array}{c}\text { Rainfall } \\
\text { Volume } \\
\text { (L) }\end{array}$ & $\begin{array}{c}\text { Runoff } \\
\text { Volume (L) }\end{array}$ & Notes \\
\hline 0 & 0 & 0.00 & 0.35 & \\
4 & 0 & 3.58 & 0.35 & runoff starts \\
7 & 0 & 6.27 & 0.35 & \\
9 & 0.2 & 8.06 & 0.62 & \\
10 & 0.35 & 8.96 & 0.83 & \\
12 & 0.5 & 10.75 & 1.04 & \\
14 & 0.7 & 12.54 & 1.32 & \\
16 & 0.9 & 14.34 & 1.59 & \\
18 & 1 & 16.13 & 1.73 & \\
20 & 1.2 & 17.92 & 2.01 & \\
22 & 1.35 & 19.71 & 2.22 & \\
25 & 1.55 & 22.40 & 2.51 & \\
27 & 1.7 & 24.19 & 2.72 \\
28 & 1.8 & 25.09 & 2.86 & \\
30 & 2 & 26.88 & 3.14 & \\
32 & 2.2 & 28.67 & 3.42 & \\
36 & 2.4 & 32.26 & 3.71 & \\
\hline
\end{tabular}




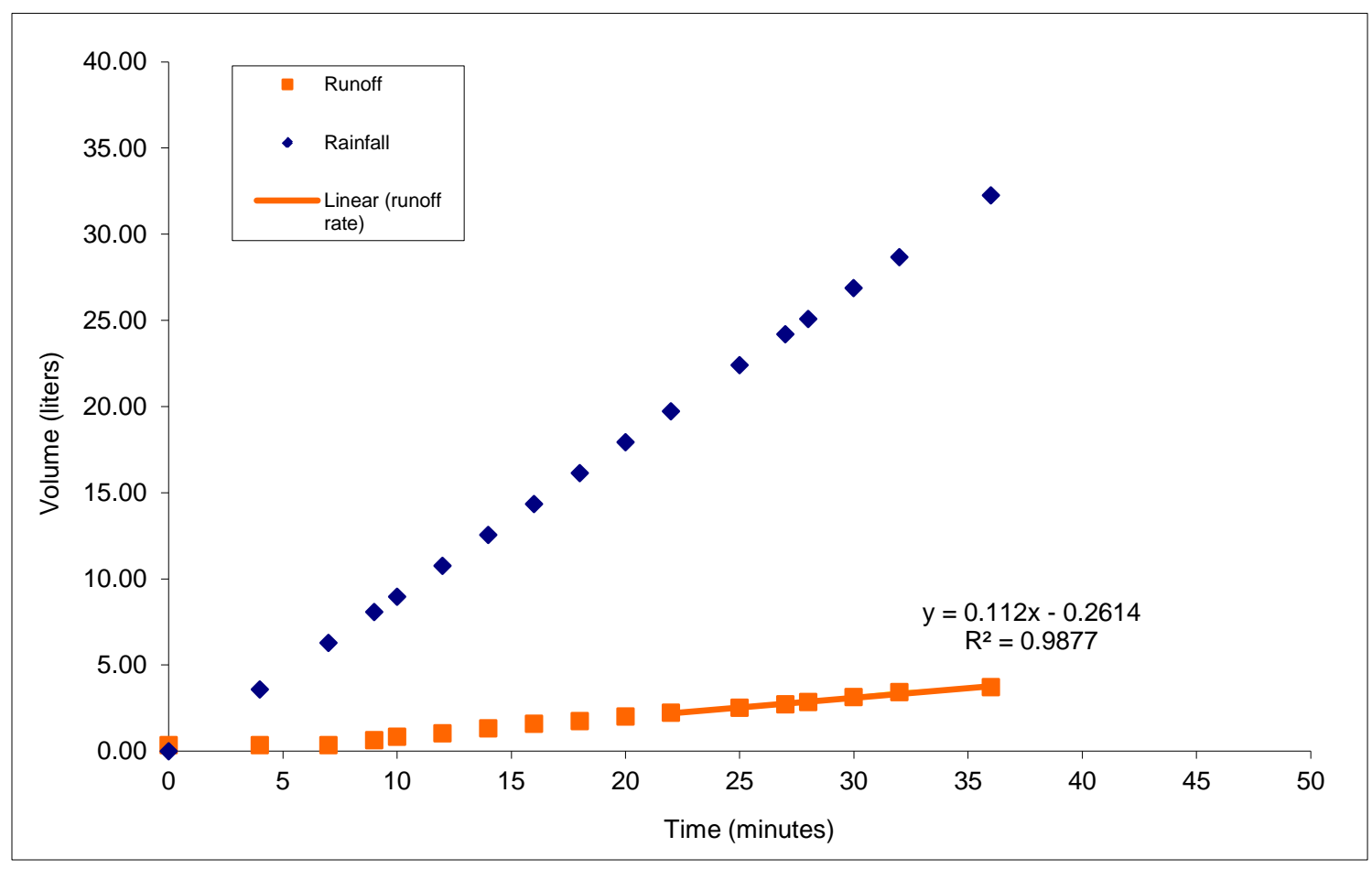

Total Rain: $\quad 32.26 \mathrm{~L} \quad 1.45$ in Total Runoff: $\quad 3.71 \mathrm{~L} \quad 0.17$ in

\begin{tabular}{rll} 
Rainfall Rate: & $0.90 \mathrm{~L} / \mathrm{min}$ & $2.42 \mathrm{in} / \mathrm{hr}$ \\
Runoff Rate: & $0.11 \mathrm{~L} / \mathrm{min}$ & $0.30 \mathrm{in} / \mathrm{hr}$ \\
\hline Infiltration & & \\
Rate: & $0.78 \mathrm{~L} / \mathrm{min}$ & $\mathbf{2 . 1 1} \mathrm{in} / \mathrm{hr}$
\end{tabular}

Results: Low runoff rate indicating higher infiltration through soil. After rainfall simulation top inch of soil removed and 50\% dry soil observed showing natural hydrophobicity although rainfall is finding avenues of infiltration. 


\section{Site 10 - Penstock Burned}

Location: Mill Creek and Upper Scotts ridge on Mill Creek side. Lockheed or State Parks property. High burn intensity.

\begin{tabular}{l|l|l|} 
Date: & $11 / 18 / 2009$ \\
Time: & $12: 10$ &
\end{tabular}

Slope: $\quad 40$ percent

Area: $0.928 \mathrm{~m}^{2}$

Vegetation: Chaparral: Knobcone pine, manzanita, scrub oak.

Soils: Shallow mudstone.

Calibration:

\begin{tabular}{|c|c|c|c|c|}
\hline Time on & 0.6 & 0.8 & 0.7 & \\
\hline Time off & 0.4 & 0.2 & 0.3 & \\
\hline & 330 & 470 & & \\
\hline Volume 1 & $\begin{array}{r}\mathrm{mL} / 30 \mathrm{~s} \\
295\end{array}$ & $\begin{array}{r}\mathrm{mL} / 30 \mathrm{~s} \\
490\end{array}$ & $460 \mathrm{~mL} / 30 \mathrm{~s}$ & \\
\hline Volume 2 & $\mathrm{~mL} / 30 \mathrm{~s}$ & $\mathrm{~mL} / 30 \mathrm{~s}$ & $415 \mathrm{~mL} / 30 \mathrm{~s}$ & Slope Corrected Rainfall Rate: \\
\hline Volume 3 & $\begin{array}{r}322 \\
\mathrm{~mL} / 30 \mathrm{~s}\end{array}$ & $\begin{array}{r}490 \\
\mathrm{~mL} / 30 \mathrm{~s}\end{array}$ & $455 \mathrm{~mL} / 30 \mathrm{~s}$ & $2.46 \mathrm{in} / \mathrm{hr}$ \\
\hline
\end{tabular}

\begin{tabular}{|c|c|c|c|c|}
\hline $\begin{array}{l}\text { time } \\
(\min )\end{array}$ & $\begin{array}{l}\text { Bucket } \\
\text { Water } \\
\text { Depth } \\
\text { (in) }\end{array}$ & $\begin{array}{l}\text { Rainfall } \\
\text { Volume } \\
\text { (L) }\end{array}$ & $\begin{array}{l}\text { Runoff } \\
\text { Volume } \\
\text { (L) }\end{array}$ & Notes \\
\hline 0 & 0 & 0.00 & 0.35 & $\begin{array}{l}\text { Start } \\
\text { drip every } 2\end{array}$ \\
\hline 2 & 0 & 1.80 & 0.35 & sec \\
\hline 4 & 0 & 3.61 & 0.35 & $\begin{array}{l}\text { small stream } \\
\text { steady }\end{array}$ \\
\hline 6 & 0.3 & 5.41 & 0.76 & stream \\
\hline 8 & 1.2 & 7.22 & 2.01 & \\
\hline 10 & 2.1 & 9.02 & 3.28 & \\
\hline 12 & 2.93 & 10.83 & 4.47 & \\
\hline 14 & 3.88 & 12.63 & 5.84 & runoff \\
\hline 16 & 4.95 & 14.44 & 7.40 & $0.74 \mathrm{~L} / \mathrm{m}$ \\
\hline 18 & 5.9 & 16.24 & 8.81 & runoff \\
\hline 20 & 6.9 & 18.05 & 10.31 & $0.73 \mathrm{~L} / \mathrm{m}$ \\
\hline 22 & 7.77 & 19.85 & 11.63 & \\
\hline 24 & 8.7 & 21.66 & 13.06 & \\
\hline 26 & 9.68 & 23.46 & 14.59 & \\
\hline 28 & 10.6 & 25.27 & 16.03 & \\
\hline 30 & 11.5 & 27.07 & 17.47 & \\
\hline 32 & 12.6 & 28.87 & 19.24 & \\
\hline 34 & 13.7 & 30.68 & 21.04 & \\
\hline 36 & 14.6 & 32.48 & 22.52 & \\
\hline 38 & 15.8 & 34.29 & 24.53 & \\
\hline
\end{tabular}




\begin{tabular}{ccccl}
40 & 16.9 & 36.09 & 26.39 & \\
42 & 18 & 37.90 & 28.28 & runoff \\
& & & & \\
44 & 19.15 & 39.70 & 30.28 & $0.79 \mathrm{~L} / \mathrm{m}$ \\
46 & 20.15 & 41.51 & 32.04 & \\
48 & 21.15 & 43.31 & 33.82 & stop rain \\
49 & 21.6 & 43.31 & 34.62 & \\
49.5 & 21.7 & 43.31 & 34.80 & \\
50 & 21.78 & 43.31 & 34.95 & \\
50.5 & 21.82 & 43.31 & 35.02 & \\
51 & 21.95 & 43.31 & 35.25 & \\
52 & 22 & 43.31 & 35.34 & \\
\hline
\end{tabular}

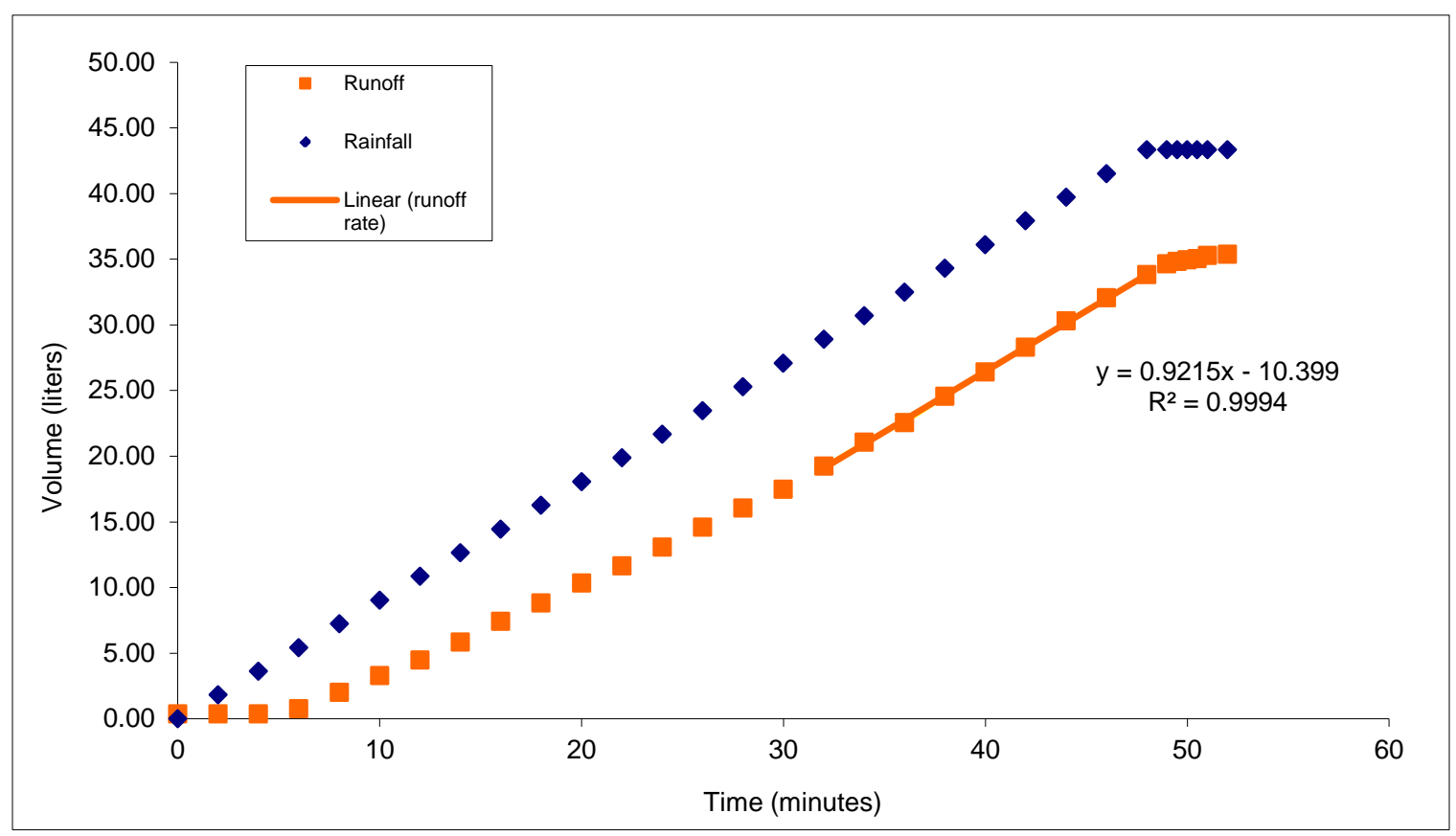

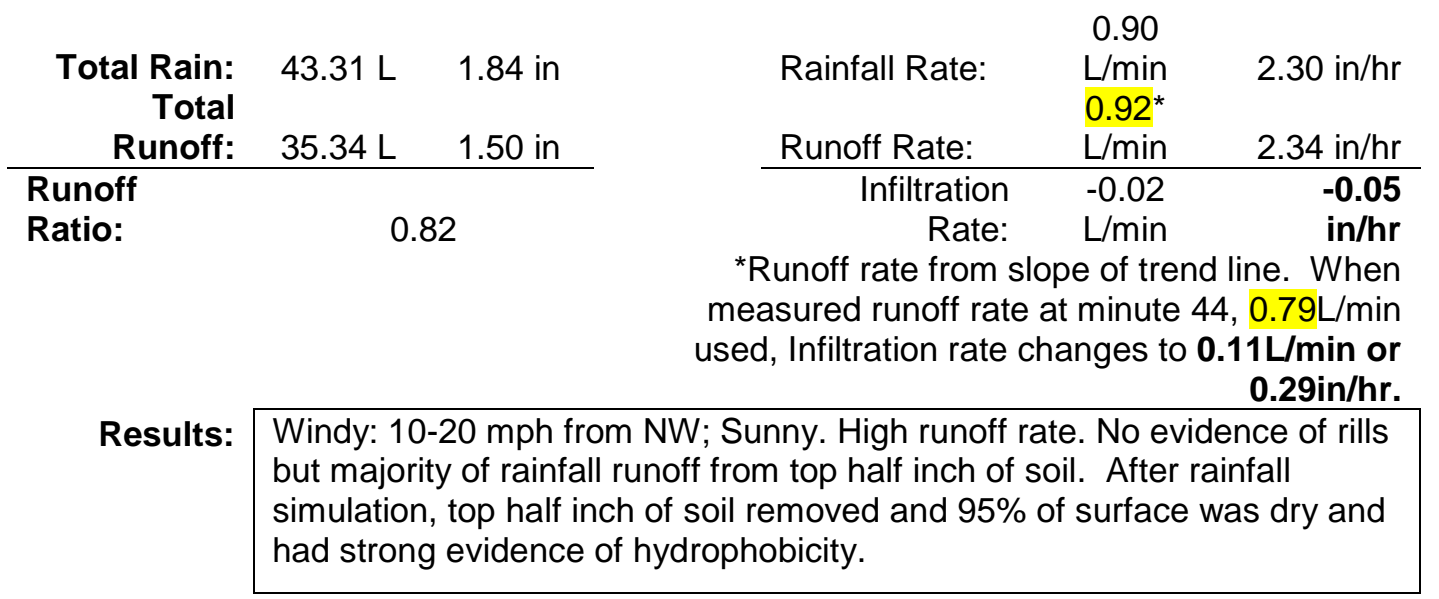




\section{Site 11 - Penstock Control}

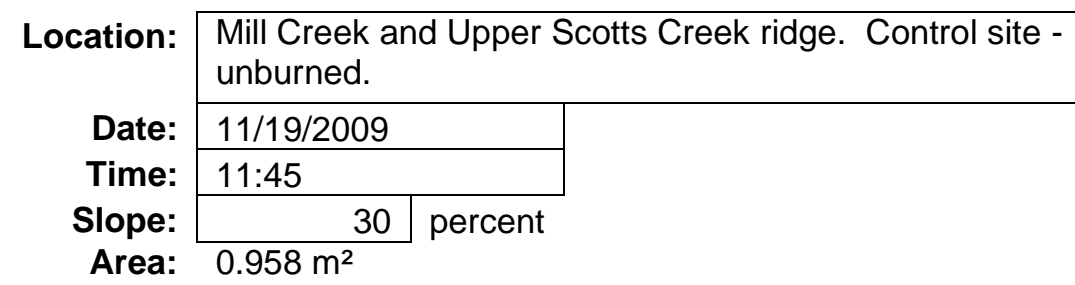

Date: $11 / 19 / 2009$

Time: $11: 45$

Slope: 30 percent

Area: $0.958 \mathrm{~m}^{2}$

Vegetation: Chaparral: knobcone pine, manzanita, oak.

Soils: Mudstone, silty clay loam. Initially slightly moist.

Calibration:

\begin{tabular}{rrrrr}
\hline Time on & 0.7 & & \\
Time off & 0.3 & & Slope Corrected Rainfall Rate: \\
\cline { 1 - 2 } Volume 1 & $438 \mathrm{~mL} / 30 \mathrm{~s}$ & & $\mathbf{2 . 2 2} \mathrm{in} / \mathrm{hr}$ & - \\
Volume 2 & $451 \mathrm{~mL} / 30 \mathrm{~s}$ & & $0.90 \mathrm{~L} / \mathrm{min}$ & - \\
Volume 3 & $450 \mathrm{~mL} / 30 \mathrm{~s}$ & & & \\
Volume 4 & $450 \mathrm{~mL} / 30 \mathrm{~s}$ & &
\end{tabular}

\begin{tabular}{|c|c|c|c|c|}
\hline time (min) & $\begin{array}{c}\text { Bucket } \\
\text { Water } \\
\text { Depth (in) }\end{array}$ & $\begin{array}{l}\text { Rainfall } \\
\text { Volume } \\
\text { (L) }\end{array}$ & $\begin{array}{c}\text { Runoff } \\
\text { Volume (L) }\end{array}$ & Notes \\
\hline 0 & 0 & 0.00 & 0.35 & $\begin{array}{l}\text { start rain } \\
\text { runoff }\end{array}$ \\
\hline 2 & 0 & 1.80 & 0.35 & starts \\
\hline 3 & 0 & 2.70 & 0.35 & \\
\hline 4 & 0.4 & 3.60 & 0.90 & \\
\hline 6 & 1.4 & 5.40 & 2.29 & \\
\hline 8 & 2.4 & 7.21 & 3.71 & $0.700 \mathrm{~L} / \mathrm{m}$ \\
\hline 10 & 3.3 & 9.01 & 5.00 & \\
\hline 12 & 4.3 & 10.81 & 6.45 & \\
\hline 14 & 5.25 & 12.61 & 7.84 & \\
\hline 16 & 6.25 & 14.41 & 9.33 & \\
\hline 18 & 7.2 & 16.21 & 10.77 & $0.706 \mathrm{~L} / \mathrm{m}$ \\
\hline 20 & 8.1 & 18.01 & 12.14 & \\
\hline 22 & 9 & 19.81 & 13.53 & \\
\hline 24 & 9.95 & 21.62 & 15.01 & \\
\hline 26 & 10.9 & 23.42 & 16.51 & \\
\hline 28 & 11.8 & 25.22 & 17.95 & $0.708 \mathrm{~L} / \mathrm{m}$ \\
\hline 30 & 12.55 & 27.02 & 19.16 & \\
\hline 32 & 13.6 & 28.82 & 20.87 & \\
\hline 34 & 14.55 & 30.62 & 22.44 & \\
\hline 36 & 15.55 & 32.42 & 24.11 & \\
\hline 38 & 16.5 & 34.23 & 25.71 & \\
\hline 40 & 17.5 & 36.03 & 27.42 & \\
\hline 42 & 18.5 & 37.83 & 29.15 & $0.714 \mathrm{~L} / \mathrm{m}$ \\
\hline 44 & 19.45 & 39.63 & 30.80 & \\
\hline
\end{tabular}




\begin{tabular}{lcccl}
48 & 21.3 & 43.23 & 34.08 & \\
50 & 22.3 & 45.03 & 35.88 & \\
52 & 23.1 & 46.83 & 37.34 & \\
54 & 23.6 & 48.64 & 38.25 & \\
56 & 24.55 & 50.44 & 40.01 & $0.710 \mathrm{~L} / \mathrm{m}$ \\
58 & 25.55 & 52.24 & 41.87 & \\
60 & 26.6 & 54.04 & 43.85 & \\
62 & 27.6 & 55.84 & 45.75 & $0.700 \mathrm{~L} / \mathrm{m}$ \\
65 & 28.9 & 58.54 & 48.25 & \\
66 & 29.4 & 59.44 & 49.23 & end \\
\hline
\end{tabular}

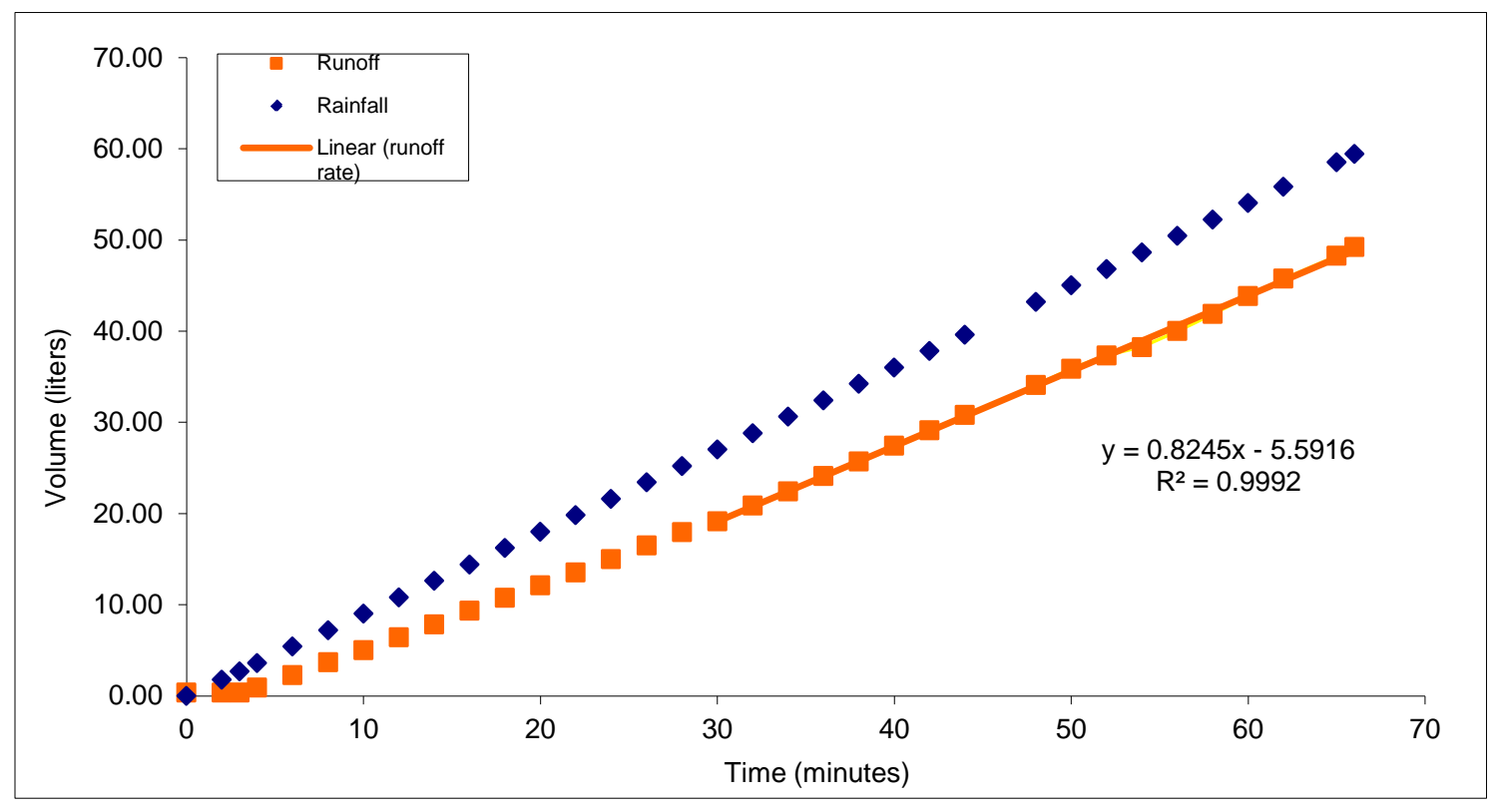

\begin{tabular}{|c|c|c|c|c|c|}
\hline $\begin{array}{r}\text { Total Rain: } \\
\text { Total }\end{array}$ & $59.44 \mathrm{~L}$ & 2.44 in & Rainfall Rate: & $0.90 \mathrm{~L} / \mathrm{min}$ & $2.22 \mathrm{in} / \mathrm{hr}$ \\
\hline Runoff: & $49.23 \mathrm{~L}$ & 2.02 in & Runoff Rate: & $0.82 \mathrm{~L} / \mathrm{min}$ & $2.03 \mathrm{in} / \mathrm{hr}$ \\
\hline Runoff & \multirow{2}{*}{\multicolumn{2}{|c|}{0.83}} & Infiltration & & \\
\hline Ratio: & & & Rate & $0.08 \mathrm{~L} / \mathrm{min}$ & $0.19 \mathrm{in} / \mathrm{hr}$ \\
\hline
\end{tabular}
Results: High runoff rate although rainfall is still infiltrating slowly. Top inch of soil removed after rainfall simulation and $50 \%$ of surface dry. Rainfall rate exceeds infiltration rate. Natural hydrophobicity observed.


Appendix E. Storm Event Data Summaries 


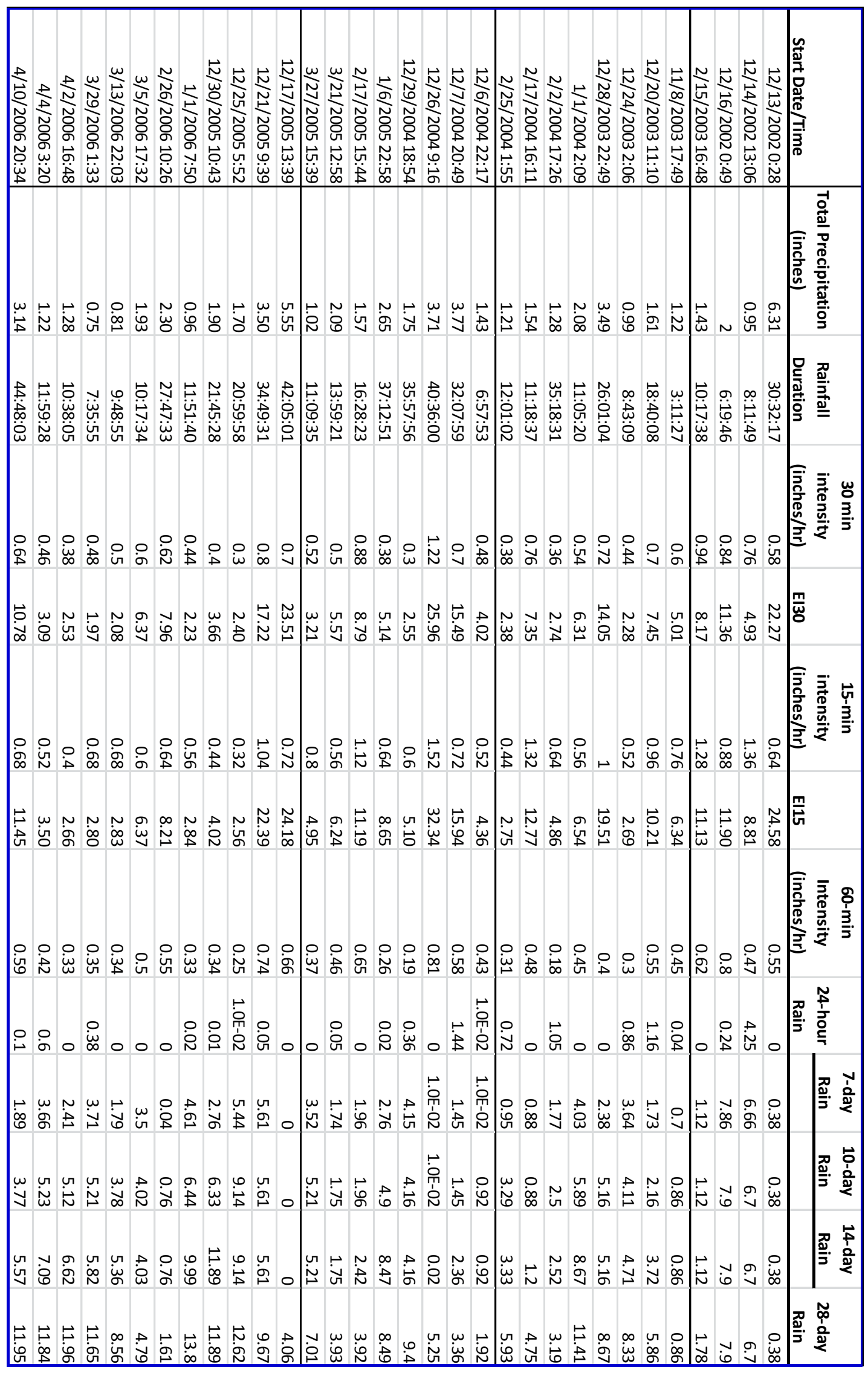




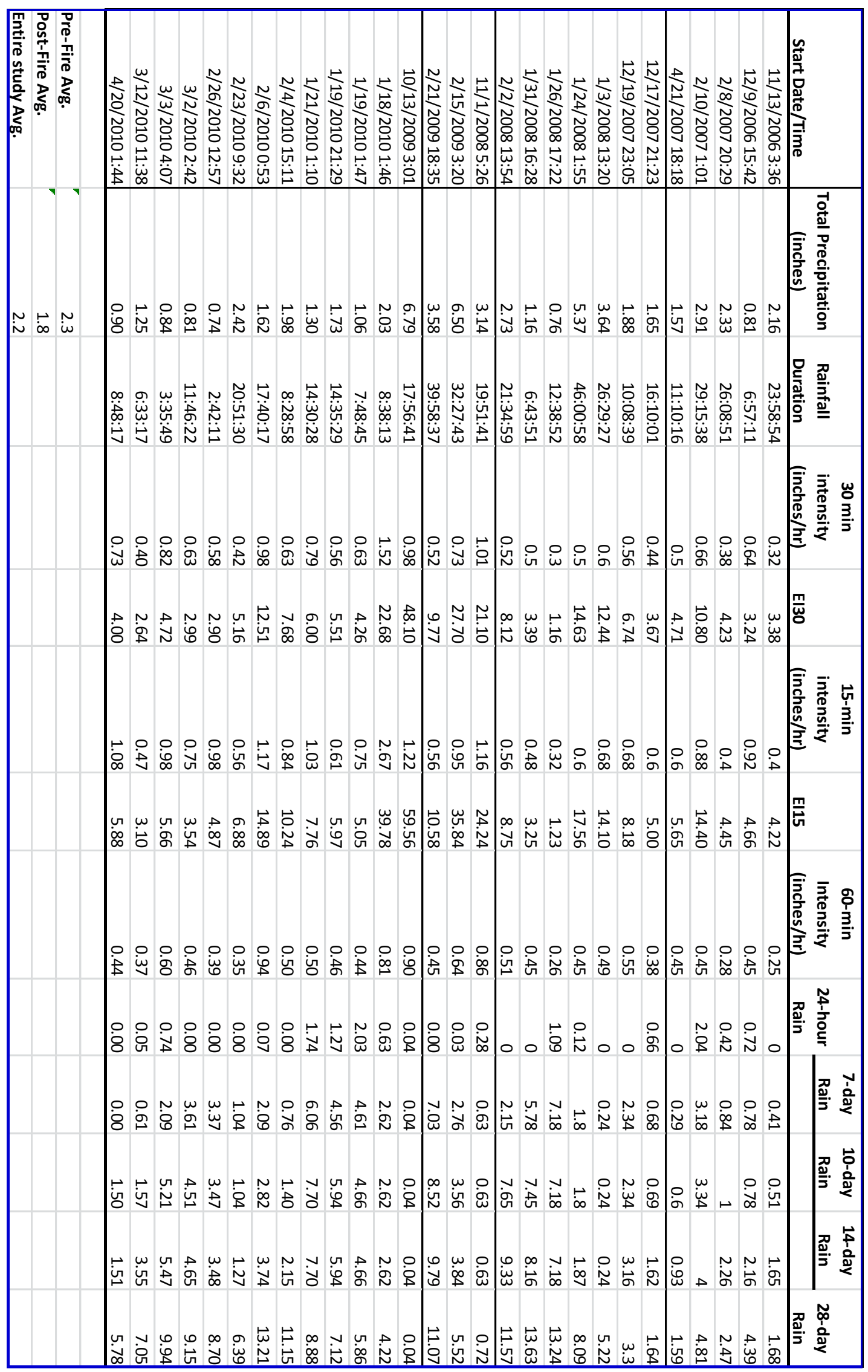




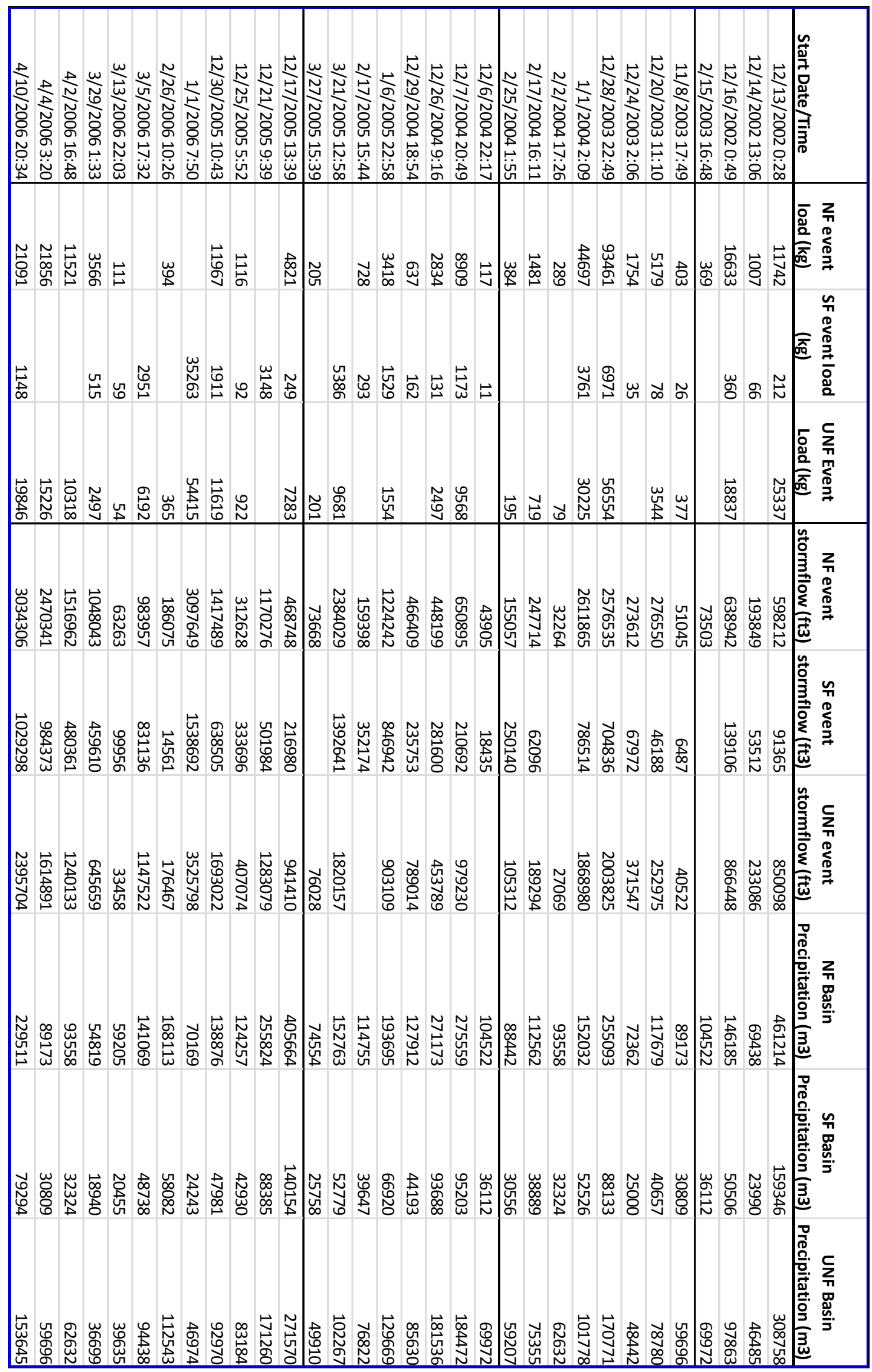




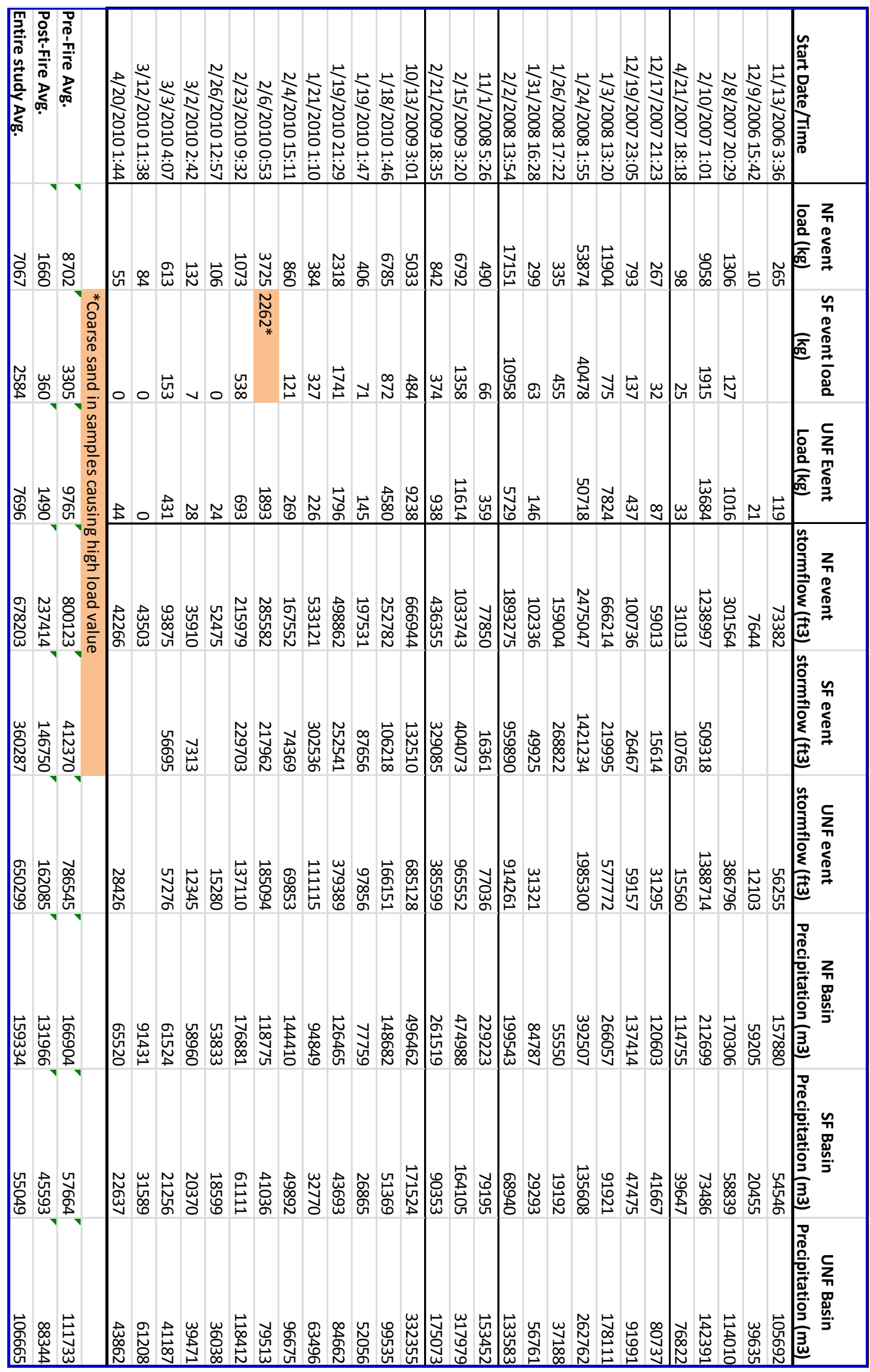




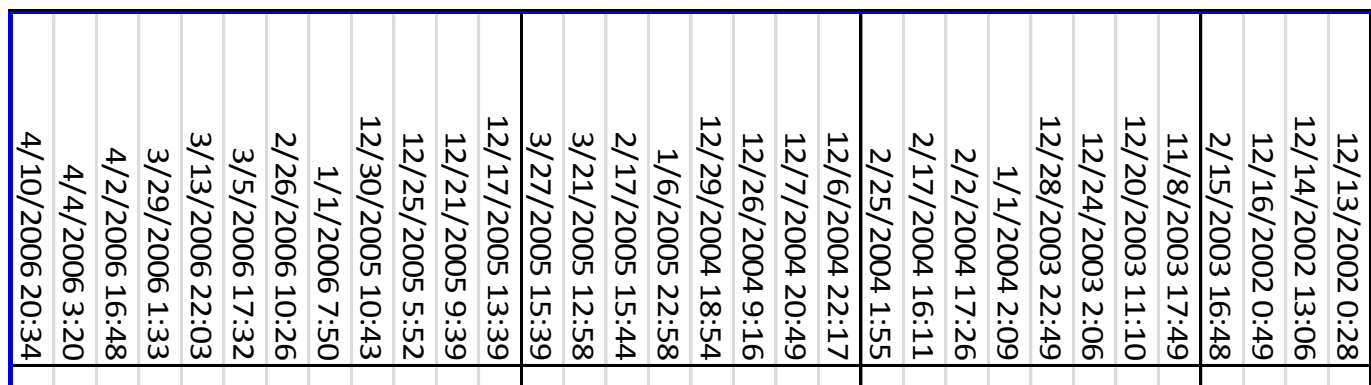

勻 N

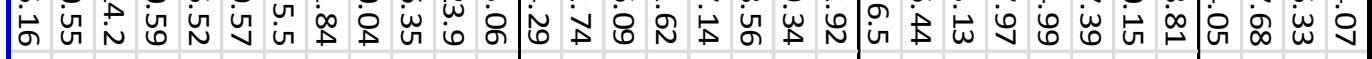

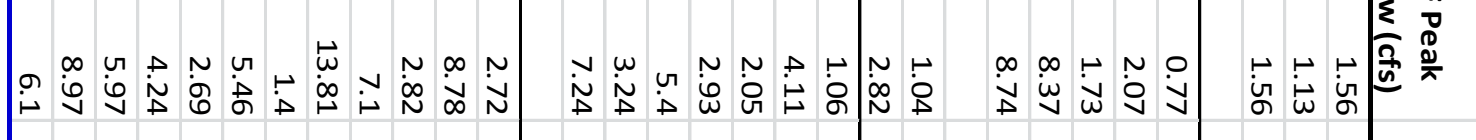

ᄁᄁ

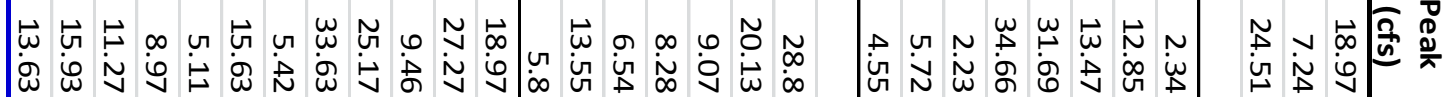

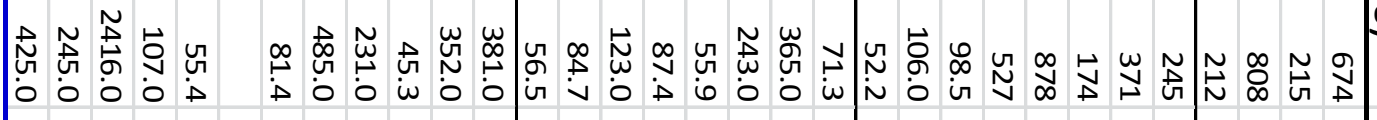

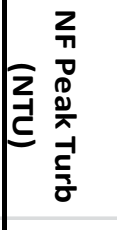

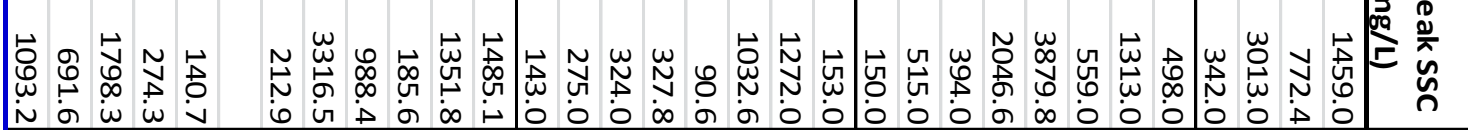

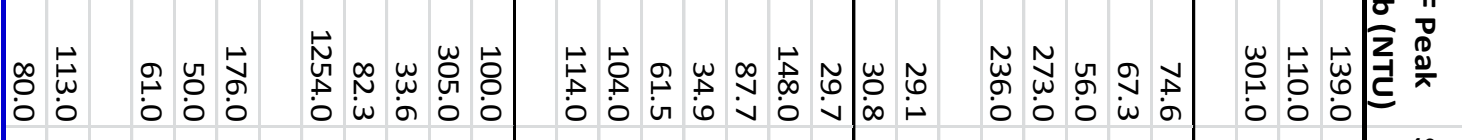

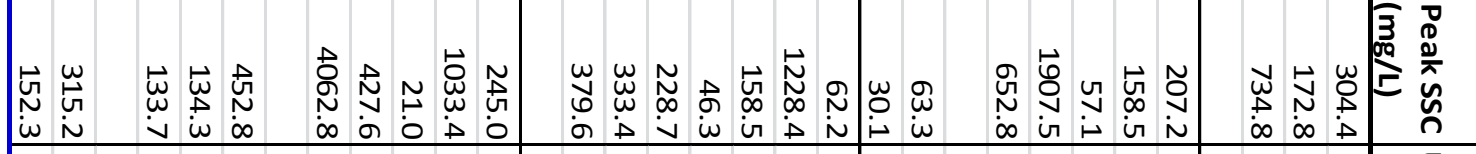

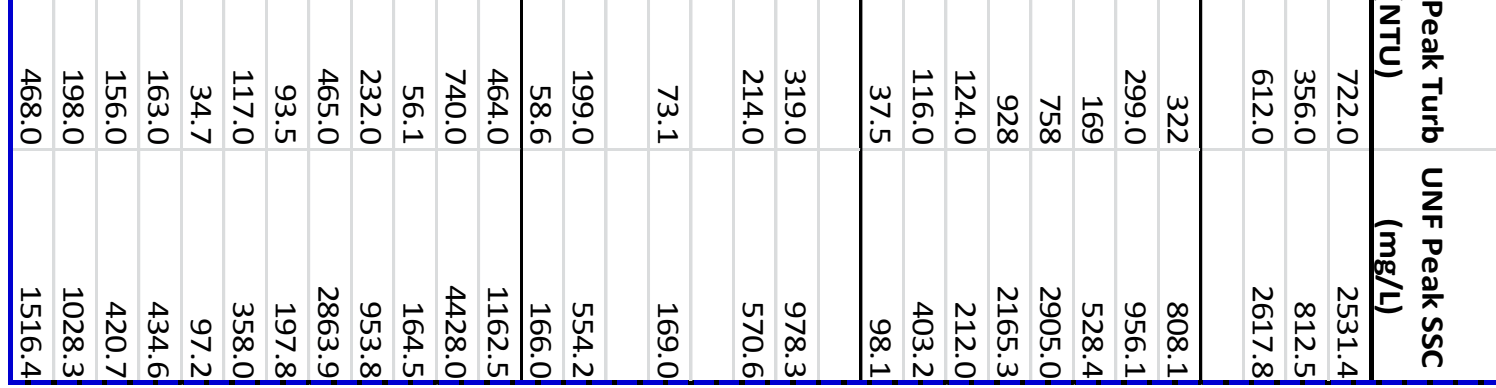




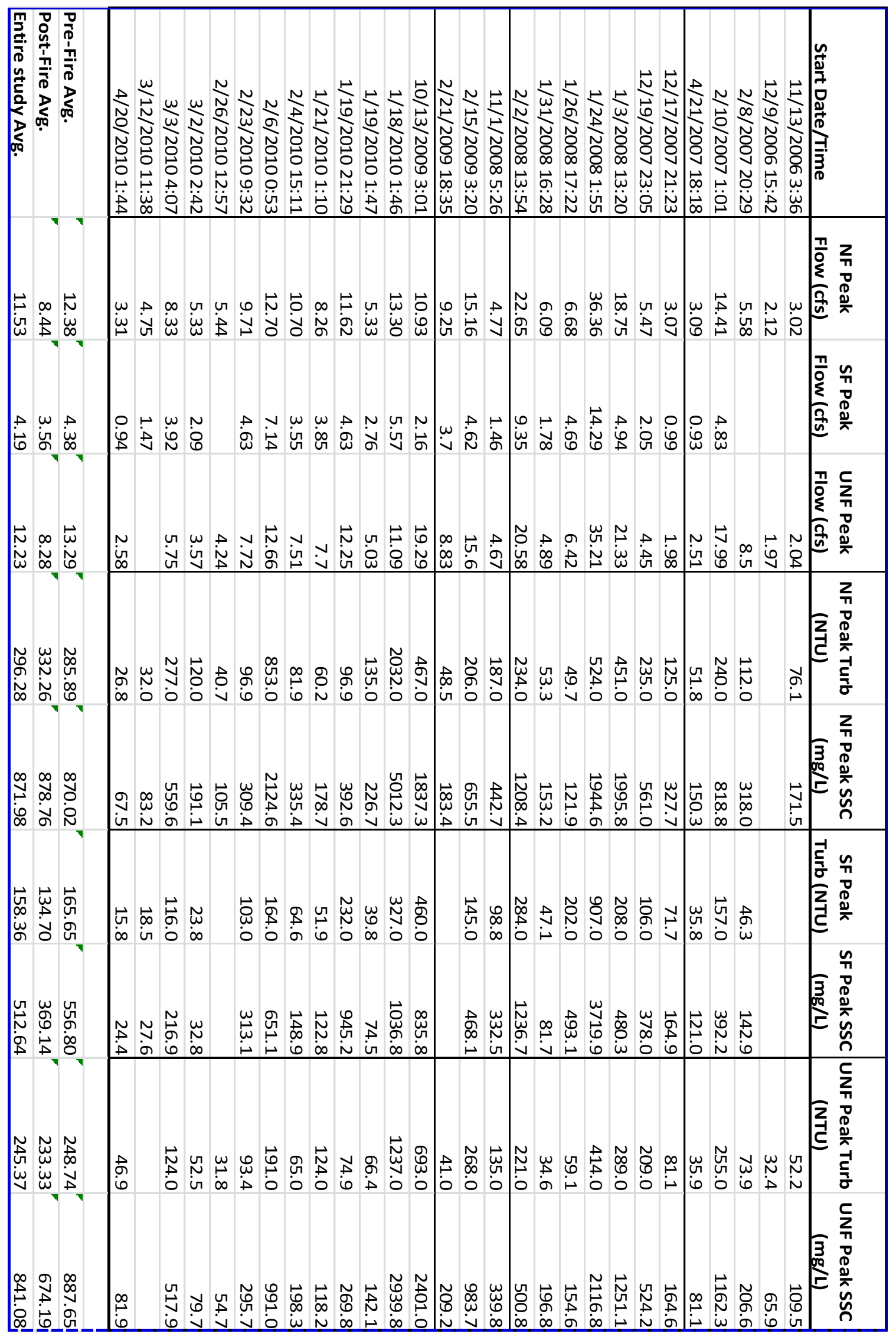




\section{Appendix F. Hillslope Erosion Plots Data}

Sediment collected per storm event $\left(\mathrm{g} / \mathrm{m}^{2}\right)$

\begin{tabular}{|c|c|c|c|c|c|c|}
\hline & $\begin{array}{l}10 / 21 / 200 \\
9\end{array}$ & $\begin{array}{l}12 / 15 / 200 \\
9\end{array}$ & $\begin{array}{l}2 / 1 / 201 \\
0\end{array}$ & $\begin{array}{l}2 / 13 / 201 \\
0\end{array}$ & $\begin{array}{l}3 / 11 / 201 \\
0\end{array}$ & $\begin{array}{c}\text { Annual } \\
\text { erosion rate } \\
\left(\mathrm{g} / \mathrm{m}^{2}\right)\end{array}$ \\
\hline Plot \#1 & 420.4 & 410.2 & 489.1 & 113.2 & 135.3 & 1568.3 \\
\hline Plot \#2 & 362.5 & 174.7 & 499.6 & 184.6 & 341.0 & 1562.3 \\
\hline Plot \#3 & 125.8 & 58.2 & 75.8 & 12.1 & 31.3 & 303.2 \\
\hline Plot \#4 & 271.0 & 73.4 & 138.9 & 52.7 & 57.3 & 593.3 \\
\hline Plot \#5 & 136.8 & 137.6 & 169.8 & 53.7 & 90.6 & 588.5 \\
\hline Plot \#6 & 93.8 & 97.3 & 104.3 & 25.2 & 45.0 & 365.6 \\
\hline Plot \#7 & 304.3 & 147.1 & 116.4 & 34.0 & 31.0 & 632.9 \\
\hline Plot \#8 & 133.9 & 124.2 & 157.2 & 46.5 & 50.2 & 512.0 \\
\hline Plot \#9 & 49.1 & 7.1 & 16.1 & 3.5 & 3.5 & 79.2 \\
\hline Plot \#10 & & & 116.9 & 21.9 & 22.5 & 161.3 \\
\hline Plot \#11 & & & 401.9 & 113.6 & 276.3 & 791.7 \\
\hline Plot \#12 & & & 40.6 & 8.2 & 6.4 & 55.1 \\
\hline
\end{tabular}

